\title{
Deep structure of the northern North Sea and southwestern Norway based on 3D density and magnetic modelling
}

\author{
Yuriy Petrovich Maystrenko', Odleiv Olesen', Jörg Ebbing ${ }^{2}$, Aziz Nasuti ${ }^{1}$
}

\author{
${ }^{1}$ Geological Survey of Norway, P.O. Box 6315 Torgard, 7491 Trondheim, Norway. \\ ${ }^{2}$ Department of Geosciences, Christian-Albrechts-Universität Kiel, Otto-Hahn-Platz 1, 24118 Kiel, Germany. \\ E-mail corresponding author (Yuriy Petrovich Maystrenko): yuriy.maystrenko@ngu.no
}

\begin{abstract}
The deep structure of the northern North Sea and the adjacent Norwegian mainland has been analysed by integrating all available structural data in combination with 3D density and magnetic modelling into a lithosphere-scale 3D structural model. The modelled configurations of the sedimentary cover and crystalline crust are consistent with the long-wavelength components of the observed gravity and magnetic fields over the study area. The first-order configurations of the top of the crystalline basement and the Moho topography have been obtained. According to the 3D density modelling, the low-density upper-crustal block beneath the Horda Platform has been shown to indicate a possible presence of metasedimentary and/or fractured granitic rocks. Possible remnants of island arc chains within the central part of the North Sea between the Laurentian and Baltican crustal domains are supported by the modelling. Moreover, based on the results of the 3D magnetic modelling, the 3D density/structural model has been differentiated into smaller crustal blocks with different magnetic properties, implying that these magnetically derived crustal blocks most likely differ lithologically from the rest of the initial density-based larger layers. Within the mainland, most of the crustal blocks with increased magnetic susceptibility are related to granitic and/or granodioritic rocks which are well mapped at the surface according to geological data. A prominent middle-upper crustal magmatic intrusion has been modelled within the northern part of the NorwegianDanish Basin. The local magnetic pattern supports a possible Permian age for this intrusion, whereas the regional magnetic pattern and known geology from the mainland indicate a Sveconorwegian origin as a more viable alternative. At the mantle level, a low-density lithospheric mantle has been modelled beneath NW Norway and adjacent offshore areas, reflecting the likely presence of an upper-mantle low-velocity zone there.
\end{abstract}

Keywords: 3D modelling, gravity and magnetic fields, density, continental shelf, Viking Graben, Horda Platform

Received 10. February 2017 / Accepted 10. July 2017 / Published online 24. October 2017

\section{Introduction}

In order to analyse the regional configuration of the crystalline crust within the northern North Sea and the adjacent Norwegian mainland, a lithosphere-scale 3D structural model has been constructed in the framework of the Crustal Onshore-Offshore Project (COOP). The investigated area covered by the 3D model (see purple frame in Fig. 1) is characterised by a smoothed bathymetry within most parts of the North Sea. Exceptions are observed only along the southern coast of Norway and within some fjords where depths to the sea floor reach more than 700-1300 m. Changes in topography are pronounced on the continent where the relief is locally more than $2000 \mathrm{~m}$ above mean sea level.

The 3D structural model covers the main tectonic units of the northern North Sea and adjacent areas of SW Norway (Fig. 2). Offshore, this includes major sedimentary depocentres within the Central and Viking grabens, the 


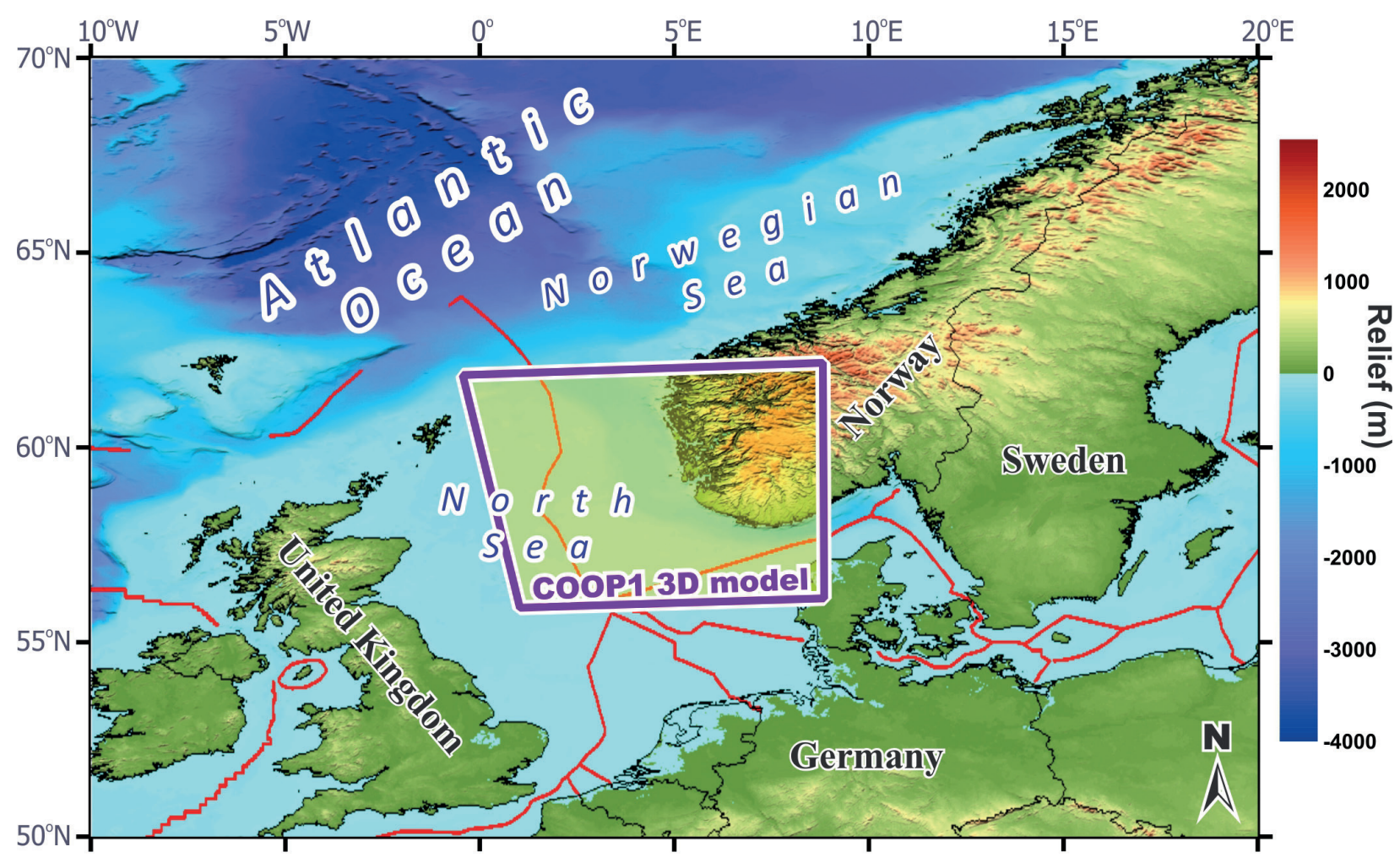

Figure 1. Overview map of northwestern Europe with the location of the 3D structural model of the northern North Sea and adjacent areas of the continent (bathymetry and topography from IOC, IHO, BODC, 2003).

East Shetland and Norwegian-Danish basins, as well as the East Shetland and Horda platforms. In addition, the model partially covers the northern parts of the uplifted Mid North Sea and Ringkøbing-Fyn highs. Onshore, the sediments are either relatively thin or mostly absent and, therefore, crystalline rocks crop out at the surface within a large part of the mainland (e.g., Sigmond, 2002).

The sedimentary cover of the study area has been intensively investigated in numerous studies for prospecting for hydrocarbons, including several regional-scale studies by Ziegler (1990), Evans et al. (2003), PGS Reservoir (2003) and Maystrenko et al. (2012, 2013). In contrast, the regional crustal structure of the northern North Sea and the adjacent continent is less well known compared with the sedimentary level. Our knowledge of the structure of the crystalline crust within the study area is mainly based on 2D deep reflection and refraction seismic lines (Calcagnile, 1982; Christie, 1982; Barton \& Wood, 1984; Klemperer \& White, 1989; Iwasaki et al., 1994; McBride \& England, 1999; Abramovitz \& Thybo, 2000; Christiansson et al., 2000; Nielsen et al., 2000; Erickson, 2004; Thybo et al., 2006; Lyngsie \& Thybo, 2007; Sandrin \& Thybo, 2008; Sandrin et al., 2009; Stratford et al., 2009; Stratford \& Thybo, 2011; Thybo \& Nielsen, 2012; Kvarven et al., 2014, 2016) and teleseismic receiver functions (Ottemöller \& Midzi, 2003; Svenningsen et al., 2007). Furthermore, several potential field studies have revealed additional important features of the deep structure within the study area both in 2D ( $₫$ m, 1973; Hovland, 1987; Olesen et al.,
2004; Lyngsie et al., 2006; Lyngsie \& Thybo, 2007; Fichler et al., 2011; Ebbing et al., 2012; Ebbing \& Osmundsen, 2013; Kvarven et al., 2014; Nirrengarten et al., 2014 and others) and in 3D (Tesauro et al., 2007; Yegorova et al., 2007; Kaban et al., 2010; Maystrenko \& Scheck-Wenderoth, 2013).

The aim of the present 3D gravity and magnetic modelling has been to integrate all recent results about the deep structure of the northern North Sea and adjacent continent with a relatively detailed configuration of the sedimentary cover into one 3D structural model. During construction of the 3D model, all available structural data have been integrated into an initial 3D model with the help of 3D density modelling to obtain a lithospherescale $3 \mathrm{D}$ model which has been structurally adjusted by combining the calculated gravity field with the observed one. Important details of the sedimentary cover, including structurally complex, density-pronounced Permian salt as an extra layer, allowed us to distinguish the major structural features of the crystalline crust within the study area. The gravity-consistent output model from the 3D density modelling has been finally examined by 3D magnetic modelling which has then been used to clarify the major structural features of the area under consideration based on the magnetic properties of the rocks. Afterwards, the 3D density model has been adjusted in accordance with the results of the 3D magnetic modelling, allowing us to obtain a comprehensive 3D structural model for the northern North Sea region. 


\section{Tectonic settings}

The crystalline crust of the northern North Sea and surrounding mainland area consists of several crustal domains resulting from long-lived processes related to the accretion of different terranes to Archaean-Proterozoic Baltica and/or collisions of Baltica with other paleocontinents during Precambrian and Palaeozoic times. Two deformation fronts, related to accretion and/or collision during the Sveconorwegian Orogeny (e.g., Bingen et al., 2008; Slagstad et al., 2013, 2017) and the terminal Caledonian (Scandian) Orogeny (e.g., McKerrow et al., 2000; Bassett, 2003; Cocks \& Torsvik, 2006), are well known at the upper-crustal level, whereas some questions concerning the lower-crustal level still remain open to debate.

In the east (Fig. 2), our model area is bounded by the Sorgenfrei-Tornquist and the Lithosphere Transition zones which separate lithospheric blocks with different thicknesses and velocities (Berthelsen, 1992; Thybo, 2001; Cotte et al., 2002; Gregersen et al., 2005; Shomali et al., 2006; Medhus et al., 2009, 2012; Hejrani et al., 2015, 2017; Kolstrup et al., 2015; Köhler et al., 2015). These deeply seated, lithosphere-scale, fault zones may possibly represent Precambrian suture zones (Olesen et al., 2004), similar to its southeastern continuation, the TeisseyreTornquist Zone, which has recently been interpreted as a Precambrian suture (Mazur et al., 2015, 2016) rather than a Caledonian structure (e.g., Dadlez, 2000). According to Mazur et al. (2015), the Caledonian suture zone between the Archaean-Proterozoic East European Craton and the Palaeozoic terranes of Central Europe must be located farther west from the Teisseyre-Tornquist Zone, with a partially extended lower crust of the East European Craton beneath the Palaeozoic lithospheric domain even farther west (Guterch \& Grad, 2006). Moreover, Balling (2000) has shown the existence of deep zones with increased seismic reflectivity within the lithospheric mantle beneath the Baltic Shield, the Tornquist Zone and the North Sea basins, indicating that the structure of the mantle beneath the study area is even more complicated by a possible presence of fossil, ancient subduction and collision zones.

In the case of the North Sea, the Caledonian suture zone is also not clearly depicted. According to integrated seismic, gravity and magnetic studies by Lyngsie et al. (2006) and Lyngsie \& Thybo (2007), the Caledonian suture zone between Avalonia, Laurentia and Baltica coincides spatially with the Viking Graben and a large part of the Central Graben. On the other hand, a block of Baltican lower crust extends through the northern North Sea

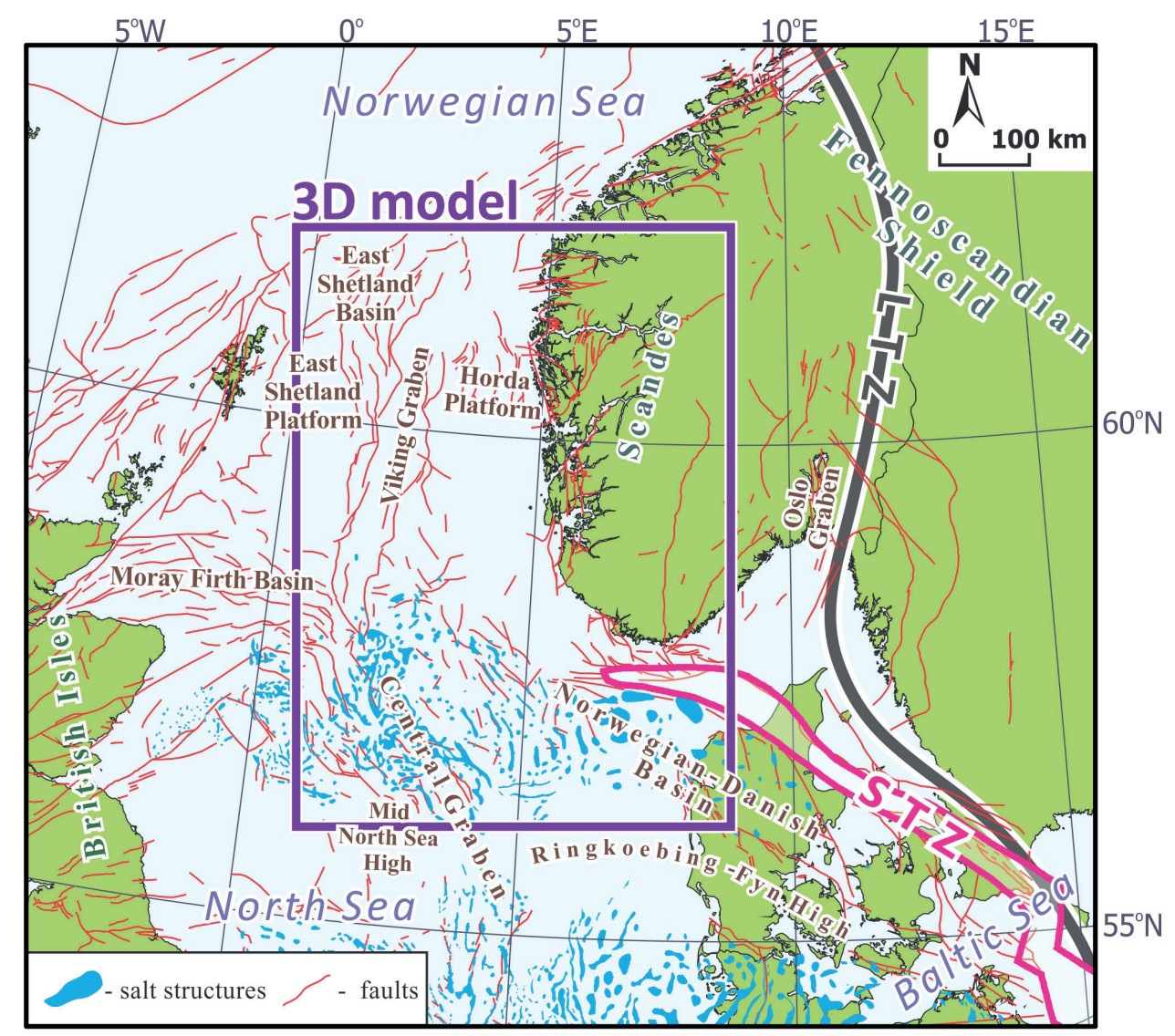

Figure 2. Tectonic settings within the study area with location of the 3D structural model (modified after Maystrenko et al., 2012, 2013). Faults are after Sigmond (2002) and LTZ is after Medhus et al. (2012). LTZ - lithospheric transition zone and STZ - Sorgenfrei-Tornquist Zone. 
towards the western flank of the Central Graben (Lyngsie et al., 2006; Lyngsie \& Thybo, 2007). In addition, using 2D potential field modelling, Fichler et al. (2011) have indicated a possibility that inherited island arc rocks are present between the Laurentian and Baltican crustal domains within the northern North Sea. Therefore, the Precambrian-Palaeozoic accretions and collisions are reflected by different thicknesses and compositions of the present-day crust and lithospheric mantle within the study area, implying that diverse physical properties have to be assigned to the differentiated crust and possibly the lithospheric mantle during the $3 \mathrm{D}$ gravity and magnetic modelling.

At the sedimentary level, the northern North Sea area is a part of the large-scale Northern Permian Basin with superimposed Meso-Cenozoic structural units (e.g., Ziegler, 1990; Evans et al., 2003), such as the Central and Viking grabens, and the East Shetland and NorwegianDanish basins. The pre-Permian sedimentary cover of the study area is not known in detail and is mainly represented by Devonian and Carboniferous sedimentary rocks (e.g., Evans et al., 2003; Fossen et al., 2016), locally including relatively thick Silurian, Ordovician and Cambrian deposits, for instance, in the Skagerrak-Kattegat area, according to Lassen \& Thybo (2012).

The study area was affected by a regional-scale Late Carboniferous-Early Permian rifting event with deposition of relatively thick clastic sediments (Plein, 1990; Ziegler, 1990; Abramovitz \& Thybo, 1999; Stemmerik et al., 2000; Heeremans \& Faleide, 2004) and was followed by precipitation of a large amount of Upper Permian evaporites, represented by mainly rock salt and anhydrite (e.g., Masytrenko et al., 2012, 2013). During post-Permian time, the Upper Permian salt has been reactivated to form various salt structures during the Meso-Cenozoic tectonic events, strongly complicating the internal structure of the sedimentary cover within the Central Graben and the Norwegian-Danish Basin. Post-Permian
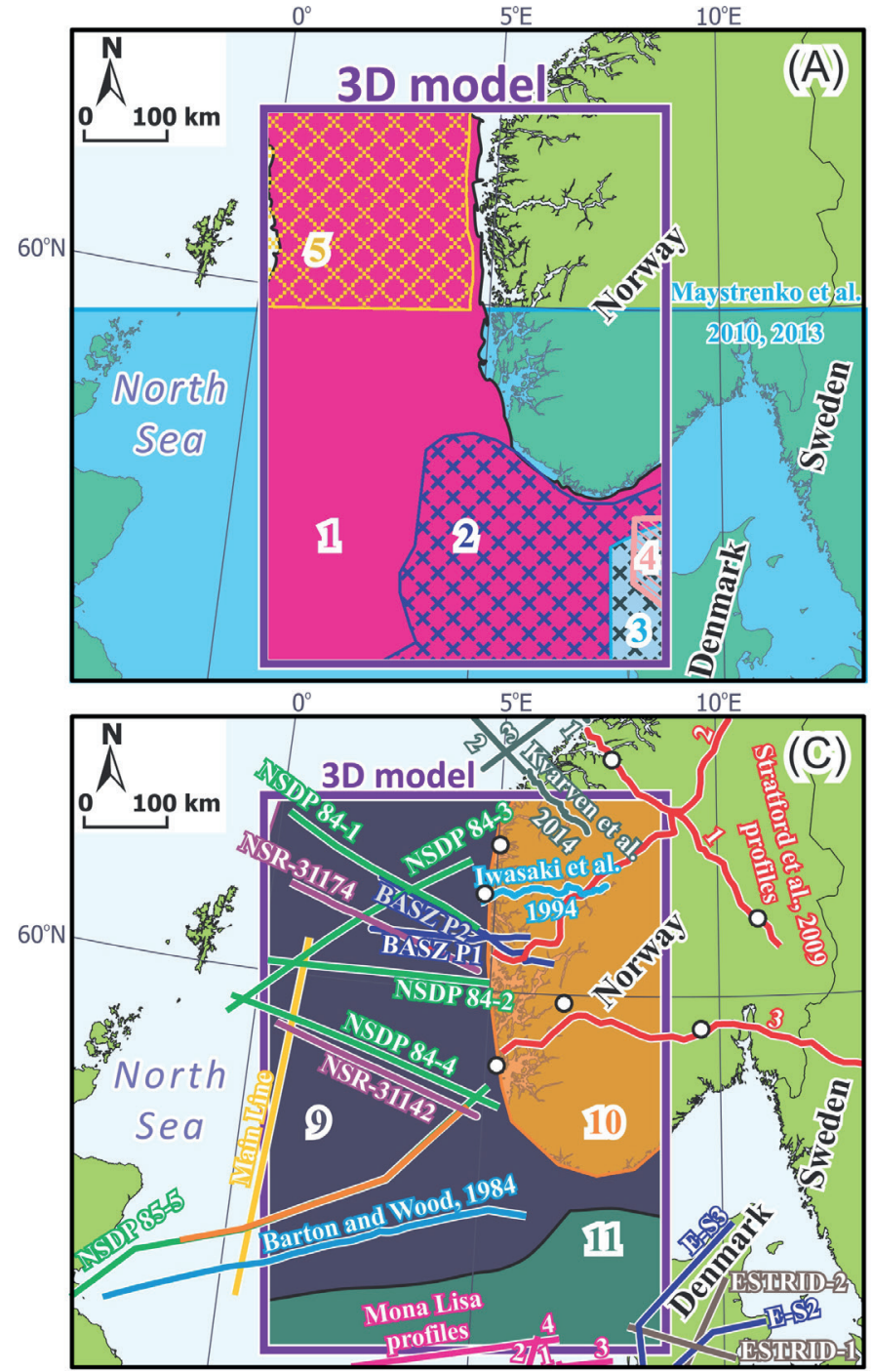

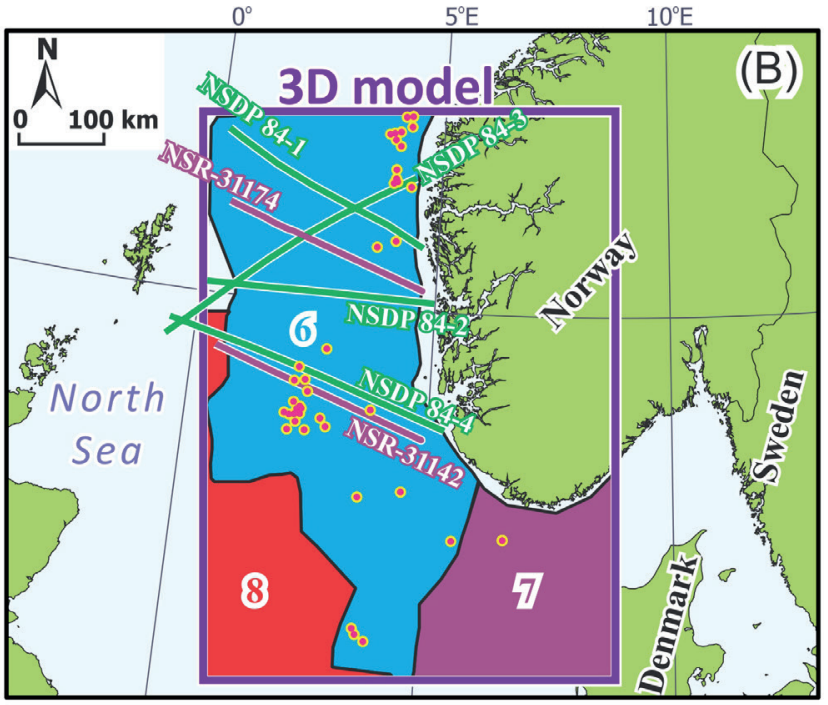

Datasets for:

(A) Sedimentary cover

1 - PGS Reservoir 2003; 2 - Vejbaek \& Britze 1994;

3 - Britze \& Japsen 1991; Japsen \& Langtofte 1991a, b;

4 - Mogensen \& Korstgard 2003; 5 - Ziegler 1990.

(B) Top of the crystalline basement

6 - Olesen et al., 2007; Ebbing \& Olesen, 2010;

7 - Lassen \& Thybo, 2012;

8 - Maystrenko \& Scheck-Wenderoth, 2013;

- - available boreholes, drilled to the top of the crystallined basement.

(C) Crystalline crust and Moho topography

9 - Ebbing \& Olesen 2010;10 - Stratford et al. 2009;

11 - Maystrenko \& Scheck-Wenderoth 2013;

O -Teleseismic receiver functions (Ottemöller \& Midzi 2003).

Figure 3. Datasets used for the sedimentary infill (A), for the top of the crystalline basement (B) and for the internal structure of the crystalline crust and for the Moho topography (C). 
tectonic differentiation of the northern North Sea was driven by several phases of tectonic activity in the Mesozoic and Cenozoic, including Triassic extensional events, Mid-Late Jurassic-Early Cretaceous extension/transtension and Late Cretaceous-Early Cenozoic compression (e.g., Badley et al., 1988; Færseth, 1996; Vejbæk, 1997; Erratt et al., 1999; Odinsen et al., 2000; Frederiksen et al., 2001a; Graversen, 2002; Vejbæk \& Andersen, 2002; Evans et al., 2003; Fraser et al., 2003; Møller \& Rasmussen, 2003; Kyrkjebø et al., 2004; Bell et al., 2014). Finally, the central part of the North Sea has been affected by a regional subsidence with deposition of more than 3 $\mathrm{km}$ of sedimentary rocks during the Cenozoic (e.g., Maystrenko et al., 2012). The nature of this Cenozoic subsidence is still under debate, possibly involving the cumulative effect of several tectonic processes (White, 1989; Morgan, 1990; Ziegler 1990; Clausen et al., 1999; Jordt et al., 2000; Kyrkjebø et al., 2000; Frederiksen et al., 2001b; Hansen \& Nielsen, 2003; Scheck-Wenderoth \& Lamarche, 2005).

\section{Datasets}

All used datasets for a construction of the initial 3D structural model of the northern North Sea and adjacent areas are shown in Fig. 3.

\section{Data for Permian-Cenozoic sedimentary infill}

Construction of the 3D model has been carried out using recently published/released structural data (borehole data, seismic reflection lines, geological maps, thickness and structural depth maps). The bathymetry has been derived from the General Bathymetric Chart of the Oceans (GEBCO) Digital Atlas (IOC, IHO, BODC 2003). For the sedimentary cover, the largest dataset was the North Sea Digital Atlas 2.0 (PGS Reservoir, 2003) which covers the entire North Sea (Fig. 3A). The TWT thickness maps of the Cenozoic, Upper Cretaceous, Lower Cretaceous, Jurassic, Triassic, Upper Permian (Zechstein) and Lower Permian (Rotliegend) have been derived from the North Sea Digital Atlas 2.0 and the obtained TWT thicknesses have subsequently been depth-converted by use of interval velocities, shown in Fig. 4.

The interval velocities of the Cenozoic (Fig. 4A) have been taken from post-Chalk interval velocities according to values provided in Japsen (1999).

The interval velocities of the Upper Cretaceous (Fig. 4B) are based on available interval velocities of the Chalk Group from borehole measurements (Japsen, 1998). On the other hand, the interval velocities of the Lower Cretaceous (Fig. 4C) have been calculated by use of the one-way time thickness of the Lower Cretaceous and the thickness of the Lower Cretaceous in metres from the available boreholes (GEUS, 2016; NPD, 2016).

In order to obtain Triassic and Jurassic interval velocities (Figs. 4D, E), the burial anomaly from Japsen $(1993,1998)$ has been adopted for the calculation of velocity anomalies in the case of both Jurassic and Triassic strata. The burial anomaly is the difference between the present-day burial depth of the sediments and the normalised depth, corresponding to normal compaction. In other words, the burial anomaly indicates the fact that the depth of the strata is anomalous relative to a reference trend (Japsen, 1998). The burial anomaly is positive within the central part of the North Sea which rapidly subsided during the Cenozoic. In contrast, the burial anomaly is negative close to the coastline of Norway where Triassic and Jurassic sediments were affected by uplift and subsequent erosion towards the end of the Cretaceous and into the Cenozoic.

The interval velocities of the Upper Permian (Zechstein) (Fig. 4F) have been calculated according to NITG (2004) by use of equation (1).

$$
\mathrm{Vi}=\mathrm{a}+\mathrm{c} /(\Delta \mathrm{T}-\mathrm{b})
$$

where $\mathrm{Vi}$ is the interval velocity $[\mathrm{m} / \mathrm{s}]$, a is the asymptote interval velocity $(4410 \mathrm{~m} / \mathrm{s}), \mathrm{c}$ is a constant $(47.36 \mathrm{~m}), \Delta \mathrm{T}$ is the one-way time thickness $[\mathrm{s}]$ and $\mathrm{b}$ is the asymptote $(-0.018 \mathrm{~s})$.

Equation (1) has the physical meaning that the interval velocities decrease with thickening of Upper Permian (Zechstein) sequence, allowing to take into account the lithological heterogeneity of the Zechstein sediments. The thick Zechstein is mostly represented by rock salt which was mobilised during several phases of salt tectonics to form various salt structures within the study area. On the other hand, the relatively thin sediments correspond to high-velocity carbonates and anhydrates which dominate within the thin Zechstein succession either as a result of differences in depositional conditions or due to post-Permian salt withdrawal.

The obtained interval velocities of the Triassic, Jurassic, Lower Cretaceous and Upper Cretaceous (Figs. 4B-E) have been cross-checked with available published data (Britze \& Japsen, 1991; Japsen \& Langtofte, 1991a; Japsen \& Langtofte, 1991b; Storvoll et al., 2005). In addition, low-pass filtering has been applied to remove some local peaks and/or artefacts from the calculated interval velocities.

In addition to the data from the North Sea Digital Atlas 2.0 (PGS Reservoir, 2003), several thickness and structural depth maps, published by the Geological Survey of Denmark (GEUS), and available well data (GEUS 2011) have been used for the southeastern part of the 3D model area within the Norwegian-Danish Basin (Fig. 3A). These maps include thickness maps of the Triassic (Bri- 


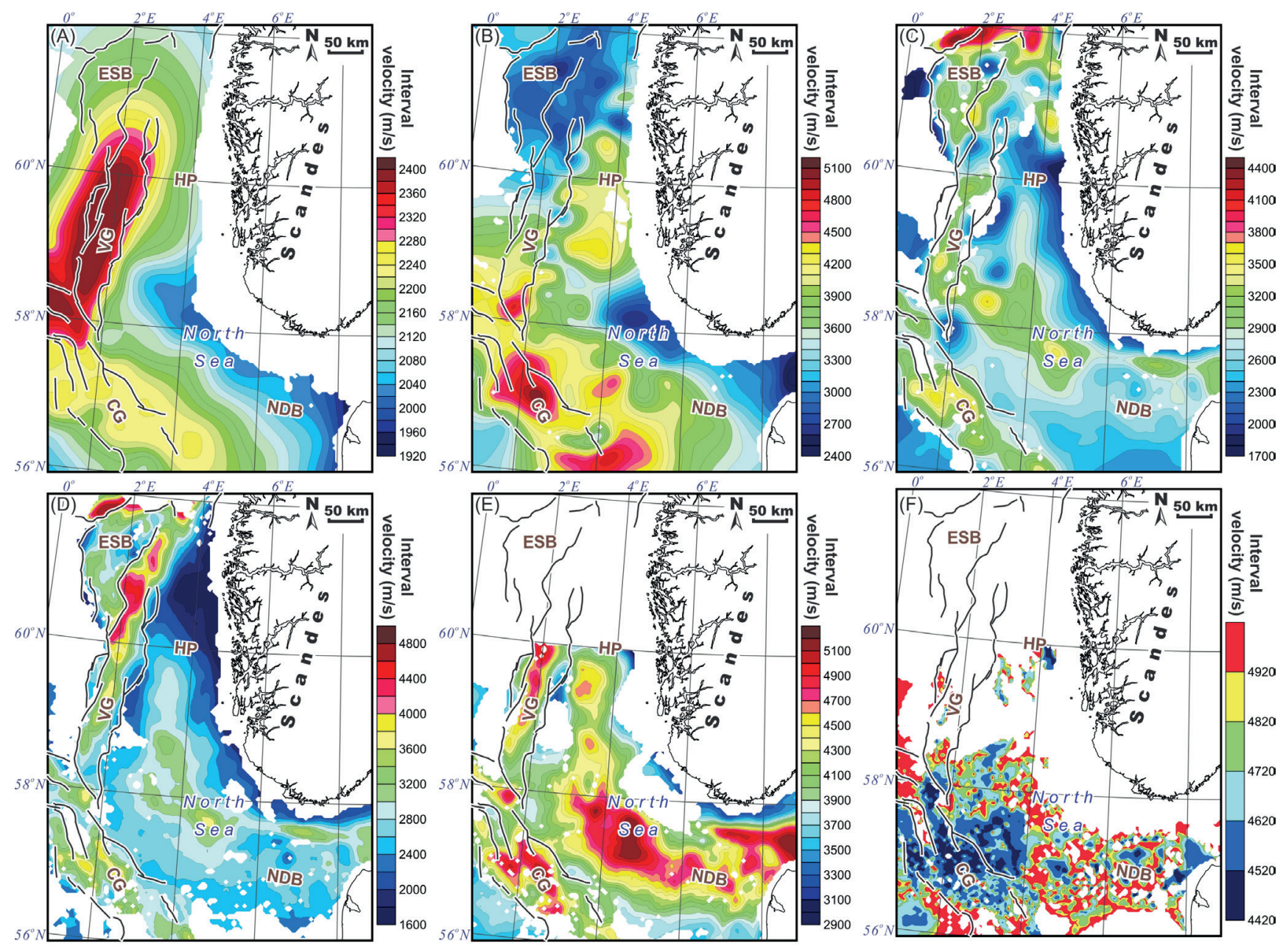

Figure 4. Interval velocities for depth conversion of the data from the PGS Reservoir North Sea Digital Atlas (PGS Reservoir, 2003): Cenozoic (A), Upper Cretaceous (B), Lower Cretaceous (C), Jurassic (D), Triassic (E) and Upper Permian (Zechstein) (F).

tze \& Japsen, 1991), Jurassic-Lower Cretaceous (Japsen \& Langtofte, 1991b), Chalk Group (Japsen \& Langtofte, 1991a) and structural depth maps of the top pre-Zechstein (Vejbaek \& Britze, 1994), top Zechstein (Britze \& Japsen, 1991) and base Chalk (Japsen \& Langtofte, 1991a) as well as the thickness of the Lower Cretaceous from Mogensen \& Korstgård (2003).

The thickness of the Triassic deposits has also partially been taken from the Geological Atlas of western and central Europe (Ziegler, 1990) for the northern part of the study area (Fig. 3A).

The marginal limits of sedimentary rocks have been cross-checked with the Geological Map of Land and Sea Areas of Northern Europe (Sigmond, 2002). In addition, the limit of the Upper Permian (Zechstein) has been partially taken from Vejbæk \& Britze (1994) and Evans et al. (2003).

All above-mentioned datasets were gridded and compiled in terms of thickness maps for the following intervals (Figs. 5 \& 6): the Cenozoic, the Upper Cretaceous, the Lower Cretaceous, the Jurassic, the Triassic, the Upper Permian (Zechstein) salt and, finally, Upper Permian (Zechstein) clastics and carbonates. Moreover, the 3D structural model of the Central European Basin System (Maystrenko et al., 2010, 2012) has been used to control the final compiled maps.

The uppermost sedimentary layer of the constructed initial 3D structural model is the Cenozoic (Fig. 5A). A wide region of thick Cenozoic sediments is observed within the central part of the North Sea along the axial parts of the Central and Viking grabens. There, the thickness of the Cenozoic is more than $3 \mathrm{~km}$. The thickness map of the Upper Cretaceous (Fig. 5B) shows that sediments are markedly thickened within the northern part of the Viking Graben and in the East Shetland Basin. Additionally, thickening of the Upper Cretaceous is locally observed within the Central Graben and the eastern part of the Norwegian-Danish Basin. The Lower Cretaceous (Fig. 5C) is characterised by pronounced thickening within the northernmost part of the study area where deposits reach more than $5 \mathrm{~km}$ in thickness. The distribution of the Jurassic sedimentary rocks (Fig. 

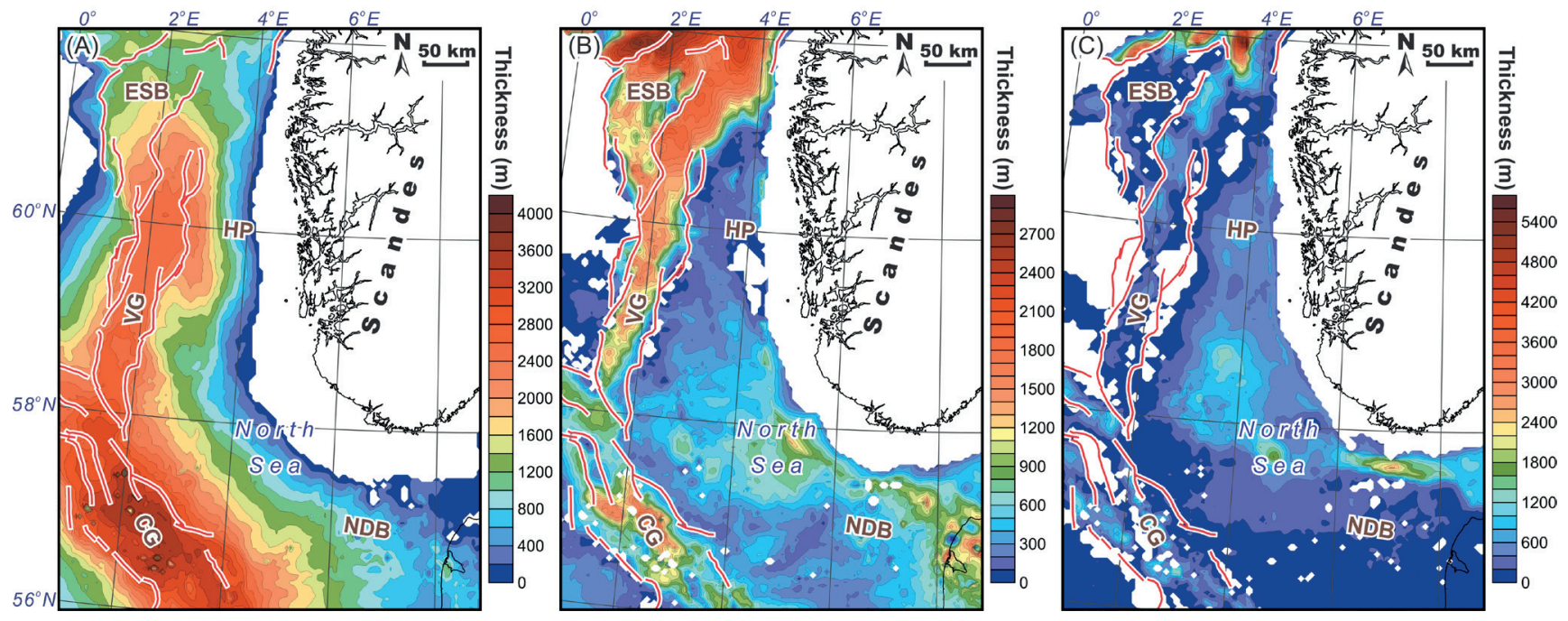

Figure 5. Thicknesses of the Cenozoic (A), the Upper Cretaceous (B) and the Lower Cretaceous (C).

6A) demonstrates that the regional Jurassic depocentre is located within the Viking Graben. Several local depocentres are observed within the Central Graben and the eastern part of the Norwegian-Danish Basin. Configu- ration of the Central and Viking grabens is clearly recognisable in the isopach maps of the Upper Cretaceous, Lower Cretaceous and Jurassic compared with the map of the Cenozoic (Figs. 5A, B, C \& 6A), reflecting the fact
Figure 6. Thicknesses of the Jurassic (A), the Triassic (B), the Upper Permian (Zechstein) salt (C) and the Upper Permian (Zechstein) clastics and carbonates (D). The detailed distribution of Upper Permian sedimentary rocks is unknown within the northern parts of the Viking Graben and the East Shetland Basin.
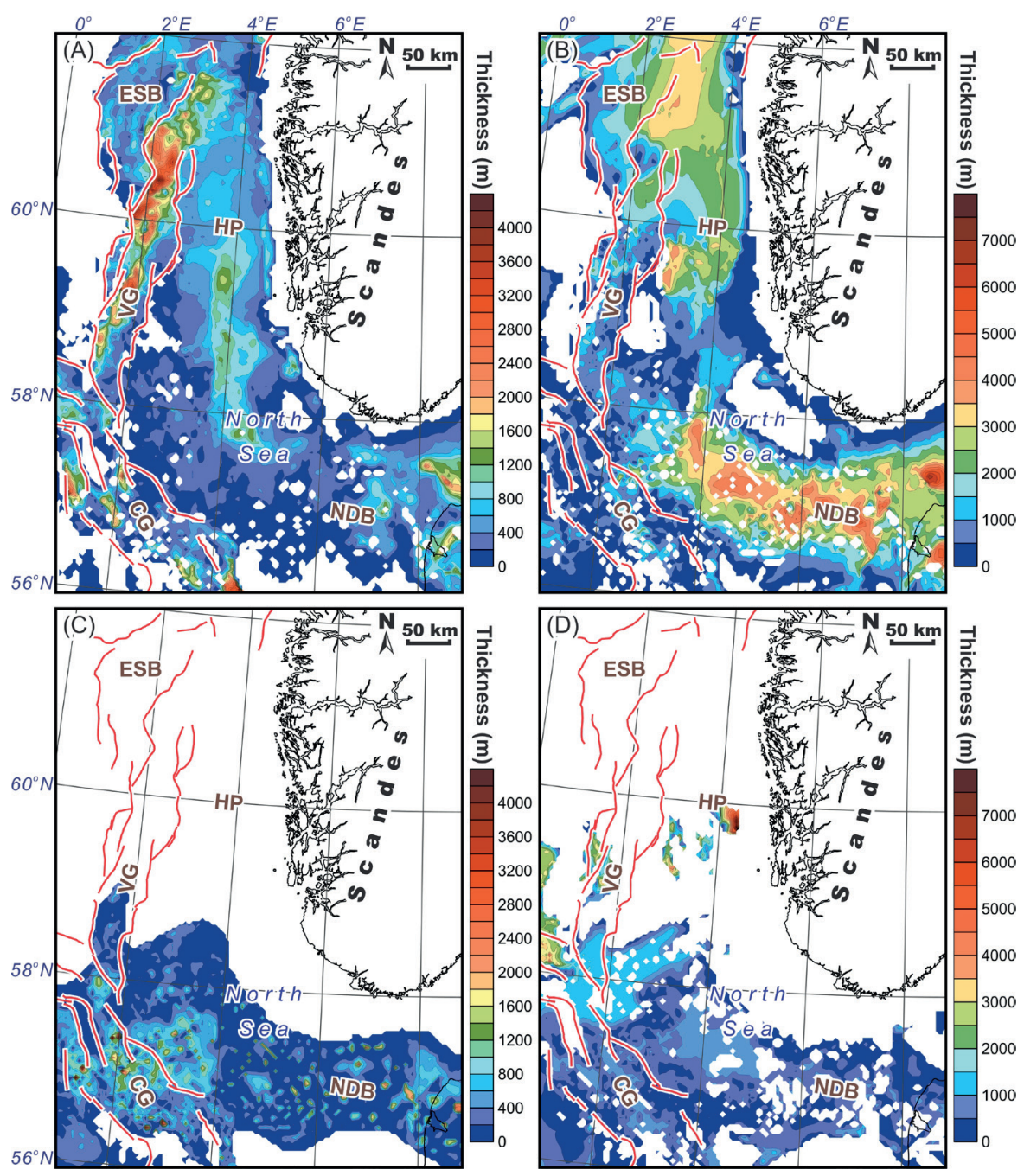

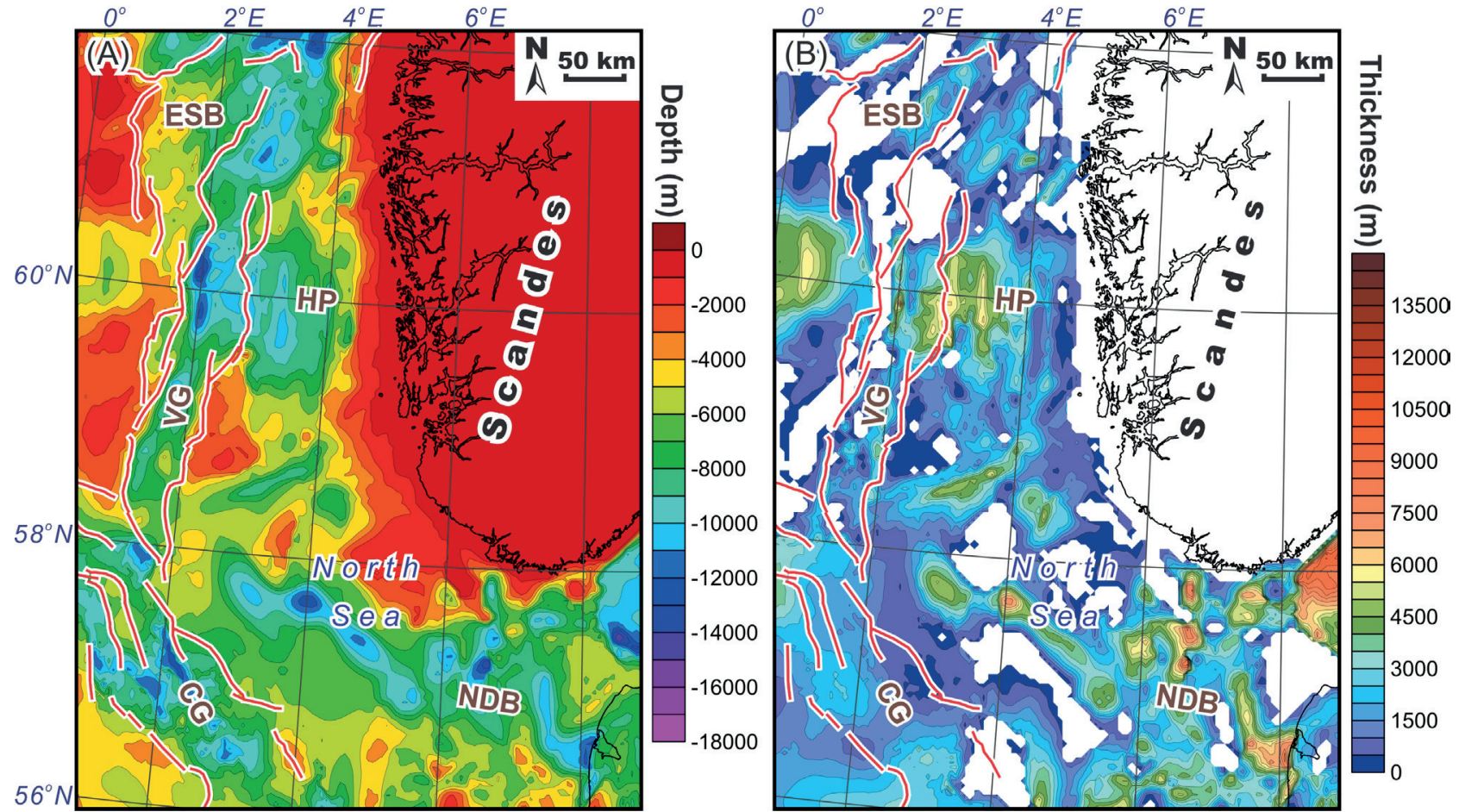

Figure 7. A) Depth to the top of the crystalline basement and (B) thickness Lower Permian and pre-Permian sedimentary rocks (Upper Permian sedimentary rocks are partially included in the north of the study area).

that the major phase of subsidence within these grabens occurred during the Jurassic-Cretaceous time interval. The Late Jurassic-Early Cretaceous was the major interval when the Jurassic-Cretaceous North Sea rift system was formed within deep and relatively narrow grabens, forming a triple junction of the Central and Viking grabens and the Moray Firth Basin. The next layer of the 3D model is the Triassic (Fig. 6B) which has a significantly thickened succession within the Norwegian-Danish Basin, the northern part of the Viking Graben and the East Shetland Basin. Depth to the base of the Triassic is approximately 5-7 km within the Norwegian-Danish Basin and reaches more than $12 \mathrm{~km}$ to the north of the Viking Graben, implying a strong degree of compaction of the Triassic and older strata. The thickness of the Upper Permian (Zechstein) salt (Fig. 6C) indicates that Zechstein salt was strongly mobilised during phases of salt tectonics which took place within the former Northern Permian Basin in response to major pulses of tectonic activity (e.g., Maystrenko et al., 2013). As a result of salt movements, the thickest Zechstein salt is localised within the areas where salt structures (walls, diapirs and pillows) were formed during post-Permian time. On the other hand, a thinning of Zechstein salt is observed within the areas where salt is strongly depleted. The Upper Permian (Zechstein) succession of clastics and carbonates (Fig. 6D) thickens considerably within local areas of the northern part of the Northern Permian Basin. There, the non-saliferous Zechstein sequence is up to $2.3 \mathrm{~km}$ thick.
Data for the top of the crystalline basement and pre-Permian sedimentary rocks

Borehole data (NPD, 2016) and three datasets of depth to the top of the crystalline basement (Fig. 3B) (Ebbing \& Olesen, 2010; Maystrenko et al., 2010; Lassen \& Thybo, 2012; Maystrenko \& Scheck-Wenderoth, 2013) represent the main datasets for the top of the crystalline basement (Fig. 3B) within the area under consideration. This top of the crystalline basement (Fig. 7A) has been used to assess the configuration of Lower Permian and pre-Permian sedimentary rocks (Fig. 7B). The initial thickness of the Lower Permian and pre-Permian strata has been calculated as the difference between the base of the Upper Permian-Meso-Cenozoic sediments and the top of the crystalline basement.

The configuration of the top of the crystalline basement (Fig. 7A) reflects the superimposed effects of all tectonic events that have affected the study area and, consequently, this surface is characterised by a complicated structure. The depth to the top of the crystalline basement is almost $14 \mathrm{~km}$ within the northeastern part of the NorwegianDanish Basin (the Skagerrak Graben) where a marked thickening of pre-Permian sediments is observed (Fig. 7B) (Lassen \& Thybo, 2012). The topography of the base of the sedimentary rocks is relatively complex throughout the rest of the North Sea where several lows and highs are recorded. The most prominent basement high, the Utsira High, is easily recognisable within the southeastern flank of the Viking Graben as well as the high in the northwestern corner of the model area. 
The distribution of the pre-Permian sediments (Fig. 7B) carries larger uncertainties than that of the Permian, Mesozoic and Cenozoic intervals within the areas where the depth to the top of the crystalline basement is great. The thickness map of the Lower Permian-prePermian (Fig. 7B) is characterised by areas of appreciable thickening within the Norwegian-Danish Basin. Within the northern part of the Norwegian-Danish Basin (the Skagerrak Graben), the pre-Permian layer is locally more than $9 \mathrm{~km}$ thick. Two Lower Permian-pre-Permian thickness maxima are located within the Horda and East Shetland platforms, reaching more than $6 \mathrm{~km}$ in thickness. The rest of the study area is characterised by a relatively thin Lower Permian-pre-Permian succession or even by an absence of sedimentary rocks.

\section{Data for the deep part of the study area}

In contrast to the sedimentary cover, information on the depth to the Moho and the lithosphere-asthenosphere boundary is more poorly constrained by the available data. During the last decade, several regional compilations of the Moho have been published by Ziegler \& Dèzes (2006), Kelly et al. (2007), Tesauro et al. (2008), Grad et al. (2009), Davis et al. (2012), Artemieva \& Thybo (2013) and Maystrenko \& Scheck-Wenderoth (2013). The major structural trend of the crust-mantle boundary is always consistent within the study area, demonstrating that the crust is thick beneath the Norwegian mainland and is relatively thin beneath the sedimentary basins within the central part of the North Sea. However, the above-mentioned Moho topographies represent only a general trend of the regional pattern of Moho configuration within the northern North Sea and, therefore, these maps are not sufficiently detailed for our present study. In this study, Moho topography and configuration of the crystalline crust have mainly been constrained by the results of interpretations of deep seismic lines (Christie, 1982; Barton \& Wood, 1984; Klemperer \& White, 1989; Iwasaki et al., 1994; McBride \& England, 1999; Christiansson et al., 2000; Erickson, 2004; Fichler et al., 2011; Ebbing \& Osmundsen, 2013; Kvarven et al., 2014, 2016) which are located within the area covered by the $3 \mathrm{D}$ structural model (Fig. 3C). The teleseismic receiver function data from Ottemöller \& Midzi (2003) have been taken to constrain the Moho topography beneath the mainland. Besides, to construct a new Moho map, the relatively detailed compilations (Fig. 3C) by Stratford et al. (2009) and Ebbing \& Olesen (2010) have been used as additional input data for 3D density modelling, also with partial use of data from Maystrenko \& ScheckWenderoth (2013). The refraction seismic results of Stratford et al. (2009) are also generally consistent with the previous receiver function results by Svenningsen et al. (2007) and can therefore be considered as reliable high-quality data for Moho depth beneath SW Norway. The lithosphere-asthenosphere boundary has been derived from previously published data, such as the seis- mologically derived base of the lithosphere by Calcagnile et al. $(1982,1997)$ as well as depth to the base of the lithosphere based on integrated studies by Artemieva et al. (2006) and Maystrenko \& Scheck-Wenderoth (2013). In addition, the depth to the lithosphere-asthenosphere boundary from Geissler et al. (2010) has been used to constrain this surface beneath the mainland where a KONO broad-band station is located. This estimate of the thickness of the lithosphere is based on $\mathrm{S}$ receiver functions.

Finally, the initial, lithosphere-scale, 3D structural model has been constructed based on the above-described data in order to determine the deep structure of the northern North Sea and the adjacent continent. The final 3D structural model is $672 \mathrm{~km}$ long and $488 \mathrm{~km}$ wide, and has a horizontal grid spacing of $4 \mathrm{~km}$.

\section{Observed gravity and magnetic fields}

The Bouguer gravity anomalies onshore (Olesen et al., 2010) and the free air gravity anomalies offshore (Andersen et al., 2010) were used during the 3D density modelling. The gravity anomaly data over the mainland have been taken from the national gravity database at NGU (Olesen et al., 2010). For the Bouguer correction, a density of $2670 \mathrm{~kg} / \mathrm{m}^{3}$ has been applied (Olesen et al., 2010). The free air gravity anomalies are represented by the new global marine gravity field DNSC08GRA from double retracked satellite altimetry (Andersen et al., 2010). The observed gravity field over the NorwegianDanish Basin (Fig. 8A) is complicated by local positive gravity anomalies, one of which, G1, is the most prominent anomaly. Besides, a small round-shaped, positive anomaly, G2, is clearly recognisable in the northernmost part of the Norwegian-Danish Basin (Fig. 8A). The observed field is also characterised by the presence of positive gravity anomalies (e.g., G2, G4, G5, G8 and G10) over the Central and Viking grabens and the EastShetland Basin. The complex-shaped positive high G2 covers the greater part of the northern Central Graben, whereas the anomaly G4 is located at the place where the Moray Firth Basin and the Central and Viking grabens form a triple junction. The gravity high G5 is located on the western flank of the Viking Graben and can be visually connected with the anomaly G8 which is located at the transition from the Viking Graben to the EastShetland Basin and is characterised by a similar trend to that of the Viking Graben. A prominent chain of positive anomalies (G6 and G7) along the western coast of Norway bounds the regional gravity low which is quite pronounced over the continent. In addition, the northwestern corner of the $3 \mathrm{D}$ model area is characterised by a broad positive gravity anomaly (G9; Fig. 8A).

Aeromagnetic data (Fig. 8B) have been compiled mostly by use of the COOP phase-1 compilation over the Norwegian sector of the North Sea (Nasuti et al., 2013) and NGU magnetic surveys NGU-60-73 and NGU-64- 

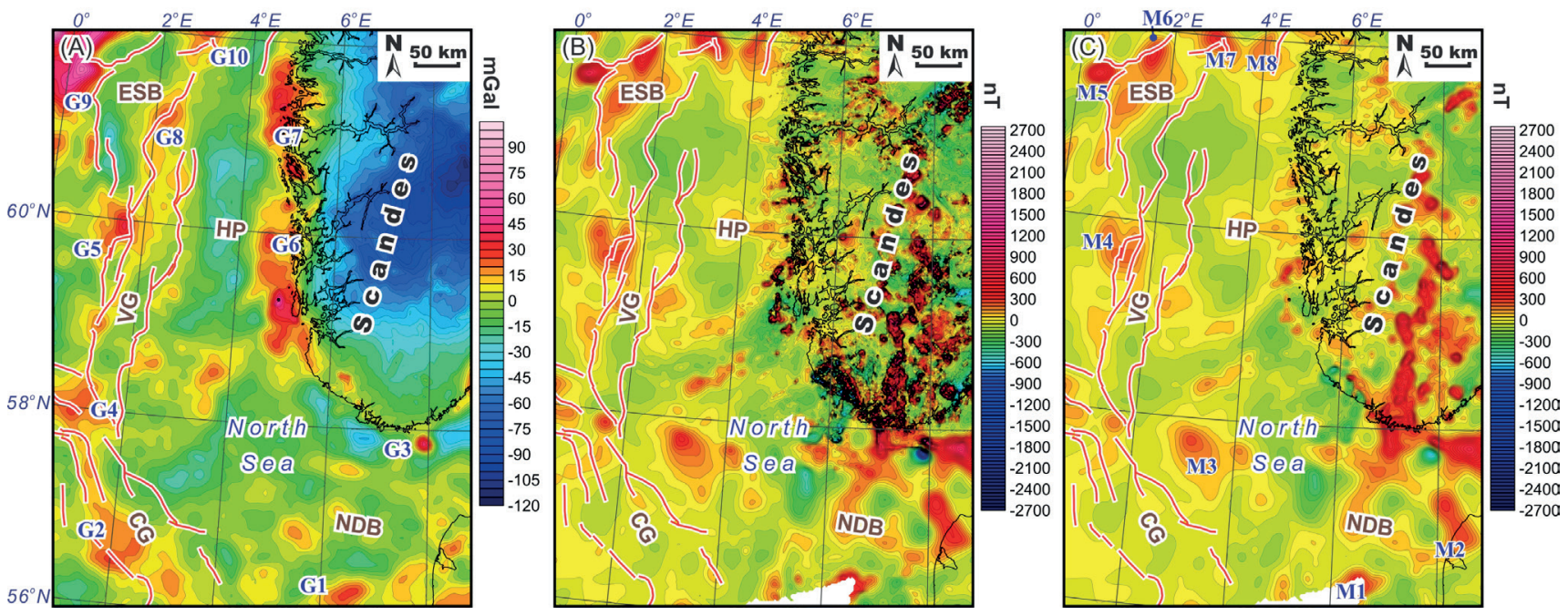

Figure 8. (A) Observed gravity anomalies within the northern North Sea and adjacent areas of the continent. Gravity data are from the NGU compilation over the continent (Olesen et al., 2010) and the DNSC08GRA global marine gravity field (Andersen et al., 2010). (B) Observed magnetic field over the northern North Sea and adjacent areas of the continent (compiled by Nasuti et al., 2013). (C) Upward-continued observed magnetic field to the altitude of $3000 \mathrm{~m}$ above sea level (a.s.l.). G1-G10 and M1-M8 - names of the important positive gravity and magnetic anomalies respectively.

76 over the Norwegian mainland. In addition, magnetic data (GAMMA5) from a compilation by Verhoef et al. (1996) over the NW North Sea, and Danish magnetic data (Danish Mag) over the Danish mainland and offshore areas have been chosen to cover the westernmost and southernmost parts of the area included in the 3D structural model. Detailed information about each particular survey is given in Table 1 and can be also obtained from Nasuti et al. (2013). Accordingly, the resolution (line spacing) of the merged surveys varies from $0.2-0.6 \mathrm{~km}$ to $2-7.5 \mathrm{~km}$.

For the aeromagnetic compilation for Norway and the North Atlantic (Olesen et al., 2010) the long-wavelength part has been replaced by a satellite-derived magnetic field model. However, here only the relevant aeromagnetic surveys have been used. On the scale of the study area and the survey size, a spatial gap is still present between the recent satellite model and the aeromagnetic data. In theory, the satellite data would still be used to analyse the longest wavelength, but are partly masked by the core field (e.g., Voorhies et al., 2002). Analysing the satellite data would require a more detailed dedicated investigation which is beyond the scope of the current study.

The aim of this study has been to investigate the regional structure of the crystalline crust rather than features associated with local inhomogeneities in the crystalline crust of the investigated area. Moreover, short-wavelength magnetic anomalies cannot be modelled with confidence at the scale of our 3D model. In order to reduce the intensity of the shortwavelength component of the observed magnetic field, the magnetic anomalies visible in Fig. $8 \mathrm{~B}$ have been upward-continued to an altitude of $3000 \mathrm{~m}$ a.s.l. (Fig.
$8 \mathrm{C})$. The upward continuation of the magnetic field has been done by use of the commercial software package Oasis Montaj by Geosoft. Comparative analysis of the magnetic fields in Figs. 8B \& 8C demonstrates that the wavelength of the upward-continued magnetic field is characterised by smoother magnetic anomalies that are especially pronounced over the continent. In contrast, the difference between magnetic fields offshore is not so strongly pronounced. Consequently, the upwardcontinued magnetic field in Fig. $8 \mathrm{C}$ has been used during the 3D magnetic modelling to model the regionalscale structural features of the northern North Sea and adjacent areas of the continent. The horizontal resolution of the merged grid with aeromagnetic anomalies (Fig. $8 \mathrm{~B}$ ) has been chosen to be $2 \mathrm{~km}$ which is sufficient for the regional-scale $3 \mathrm{D}$ magnetic modelling.

The geomagnetic reference field parameters have been chosen to be mean values for the largest magnetic survey (CNAS-10) of the compilation and these parameters have been set as constant for the whole model area: the total intensity of the magnetic field is $50,527 \mathrm{nT}$, declination is $-1.49^{\circ}$ and inclination is $72.09^{\circ}$. According to previously performed sensitivity tests (Marello et al., 2013), spatially varying parameters of the geomagnetic reference field, calculated separately for each particular magnetic survey, do not significantly change the modelled magnetic field. Actually, in order to consider spatially variable parameters of the geomagnetic reference field, the magnetic anomalies can be reduced to the pole. On the other hand, the difference between the calculated magnetic anomalies using a constant mean value of the reference field and magnetic anomalies reduced to the pole demonstrates that the inaccuracy is approximately equal to $2 \mathrm{nT}$ (Marello et al., 2013); 
Table 1. Aeromagnetic surveys used during the 3D magnetic modelling.

\begin{tabular}{|c|c|c|c|c|c|}
\hline Year & Area & Operator & Survey name & Sensor elevation $[\mathrm{m}]$ & Line spacing $[\mathrm{km}]$ \\
\hline $1955-65$ & NW North Sea & British Geol. Survey & GAMMA & 300 & 2 \\
\hline 1965 & Part of Danish territory & Hunting & Danish Mag & 750 & $3-6$ \\
\hline $1960-73$ & Norwegian mainland & NGU & NGU-60-73 & $300 \mathrm{~m}$ a. ground & 1 \\
\hline $1964-76$ & Norwegian mainland & NGU & NGU-64-76 & $150 \mathrm{~m}$ a. ground & $0.4-0.5$ \\
\hline 1974-75 & Northern North Sea & NGU & NGU-74-75 & 300 & $1-7$ \\
\hline 1986 & Trøndelag Platform & Hunting & Hunting-86 & 200 & 2 \\
\hline 1993 & N. Viking Graben & NGU & Viking-93 & 150 & $0.5-2$ \\
\hline 1994 & Gjølanger area & NGU & Dale-94 & $30-40$ & 0.1 \\
\hline 1994 & S. Viking Graben & Amarok/TGS & VGVG-94 & 160 & 0.2 \\
\hline 1994 & Central Graben, North Sea & TGS & VGCG-94 & - & $0.6-0.8$ \\
\hline 1995 & Central Graben, North Sea & TGS & CGAM-95 & - & $2.5-7.5$ \\
\hline 1995 & East Troll, North Sea & TGS & VGET-95 & - & $0.2-0.6$ \\
\hline 1995 & Sokndal & NGU & Sokndal-95 & $30-40$ & 0.1 \\
\hline 1996 & Quadrant 17, North Sea & TGS & Q17 & - & $0.45-1.2$ \\
\hline 1996 & Skagerrak & NGU & SAS-96 & 150 & 2 \\
\hline 2006 & ROGFAST project & NG & ROGAS-06 & 60 & 0.25 \\
\hline 2010 & Central North Sea & NG & CNAS-10 & 115 & 1 \\
\hline 2010 & Bergen-Stavanger Region & FUGRO & BESTAS-10 & - & - \\
\hline 2011 & Stad region (western coast of Norway) & Novatem & SAS-11 & $140-1450$ & 0.25 \\
\hline
\end{tabular}

thus, this value of the inaccuracy is much lower than the uncertainties of the 3D model and can therefore be neglected in this regional-scale study.

At the large scale, the observed magnetic field (Fig. 8B) is characterised by the predominance of long-wavelength magnetic anomalies offshore, whereas short-wavelength anomalies prevail over the Norwegian mainland. This regularity in wavelength distribution is mostly related to the fact that crystalline rocks are exposed over the continent. Besides, the low-magnetic sediments are relatively thick offshore (Figs. 5-7) and, therefore, magnetic crystalline rocks are deeply located beneath the Central and Viking grabens and the Norwegian-Danish Basin (Fig. 7A). Consequently, a short-wavelength component of the magnetic signal is weak offshore due to the deep location of the crystalline basement beneath a thick sedimentary cover.

The main feature of the magnetic field over the continent is related to a pronounced NE-SW- elongated chain of positive anomalies. This chain of anomalies clearly correlates with granitic/granodioritic complexes which are exposed at the surface or located at shallow depth (e.g., Sigmond, 2002).
Offshore, the observed magnetic field is characterised by the presence of the 8 major positive anomalies, defining the origin of which has been the main task during the 3D magnetic modelling. The magnetic field along the southwestern coastline of Norway has a relatively complex pattern compared to the rest of the offshore areas, reflecting the shallow position of the crystalline basement (cf., Figs. 7A \& 8B). The partially data-covered positive anomaly $\mathrm{M} 1$ and the NWSE-elongated magnetic high M2 (Fig. 8B, C) predominate over the studied part of the Norwegian-Danish Basin. The prominent, broad, positive magnetic anomaly M3 (Fig. 8B, C) is located between the northern part of the Central Graben and the Norwegian-Danish Basin. The next prominent magnetic high is M4 which is located over the northwestern flank of the Viking Graben. The observed magnetic field (Fig. 8B, C) over the western and northern parts of the East Shetland Basin is complicated by several, long- to short-wavelength, positive magnetic highs (M5, M6, M7 and M8). On the other hand, the southeastern part of the East Shetland Basin and the northern part of the Viking Graben are characterised by the presence of a broad magnetic low. 


\section{Methods}

The above-described input data provide a good starting point for the 3D density and magnetic modelling and have been used to verify the geometry of the initial 3D model. In particular, the 3D density modelling helped to evaluate the regional-scale deep structure of the crystalline crust within the northern North Sea and adjacent areas of the continent, whereas the 3D magnetic modelling has been carried out in order to understand some of the structural features of the crystalline crust according to the magnetic properties of the rocks. During the 3D magnetic modelling, the 3D density model has been subdivided into several crustal blocks which have been modelled based on the magnetic properties of the rocks. At the final stage, the 3D density model has been adjusted in accordance with the results of the 3D magnetic modelling.

\section{Densities and magnetic properties}

During the 3D density modelling, densities of sedimentary rocks have been set to be dependent on depth in order to consider the compaction of sedimentary rocks with increasing depth (Table 2), whereas densities for each layer of the crystalline crust have been assigned to be constant (Table 3). The exponential functions of the increasing densities with depth are mainly based on the measured densities for different stratigraphic units in boreholes within the northern North Sea according to Zervos (1986) and within the central North Sea according to Sclater \& Christie (1980). The inferred densities of the sedimentary layers are also in agreement with previously published values for the northern North Sea (e.g., Christiansson et al., 2000; Fichler et al., 2011).

In order to consider the depth-dependent densities, the following exponential function (2) has been derived for the sedimentary rocks:

$$
\mathrm{r}(\mathrm{z})=\rho_{\mathrm{am}}-\rho_{\mathrm{d}}^{*} \mathrm{e}^{\left(\mathrm{c}^{*}-\mathrm{z}\right)}
$$

where $\rho$ is density $\left[\mathrm{kg} / \mathrm{m}^{3}\right], \rho_{\mathrm{am}}$ is average matrix density $\left[\mathrm{kg} / \mathrm{m}^{3}\right], \rho_{\mathrm{d}}$ is density difference $\left[\mathrm{kg} / \mathrm{m}^{3}\right], \mathrm{c}$ is coefficient of compaction with depth $\left[\mathrm{m}^{-1}\right]$ and $\mathrm{z}$ is depth below sea level $[\mathrm{m}]$. Compaction parameters for each sedimentary layer are shown in Table 2.

The same average matrix density $\left(2700 \mathrm{~kg} / \mathrm{m}^{3}\right)$ has been taken to represent the matrix density of each layer, reflecting both lateral and vertical uncertainties in the lithology of sedimentary layers within the study area.

The uppermost sedimentary layer is represented by relatively low-compacted, Cenozoic, clastic sedimentary rocks and, therefore, has the lowest average density. The dominance of chalky limestones has raised the average density of the Upper Cretaceous compared to the Cenozoic. This fact is reflected by the changes of compaction parameters in Table 2 in comparison to those of the Cenozoic. Due to similarities in lithological composition, the same depth-dependent densities have been assigned to the Lower Cretaceous and Jurassic strata which are predominantly composed of mudstones/siltstones. Therefore, the same compaction parameters (Table 2) have been used for the Lower Cretaceous-Jurassic interval. The derived densities of the Triassic reflect a relatively high degree of compaction of the Triassic sedimentary rocks compared with the overlying layers, as a consequence of their greater burial depth. Compaction parameters of this layer have thus been inferred to consider the increased compaction.

The Upper Permian (Zechstein) rock salt has been modelled with an average density of $2300 \mathrm{~kg} / \mathrm{m}^{3}$, reflecting some uncertainties in the shape and composition of this geometrically complex layer. On the other hand, the density of pure rock salt is lower than $2300 \mathrm{~kg} / \mathrm{m}^{3}$.

The density of Upper Permian carbonates, anhydrites and clastics has a relatively high value and, therefore, the depth-dependent densities have been calculated assuming an increased degree of compaction compared with the overlying layers. The average density of Upper Permian anhydrites is higher than the average density of carbonates and especially clastic material. Distribution of

Table 2. Compaction parameters of sedimentary layers.

\begin{tabular}{cccc}
\hline Sedimentary layer & $\begin{array}{c}\text { Average matrix density } \\
\rho_{\mathrm{am}}\left[\mathrm{kg} / \mathrm{m}^{3}\right]\end{array}$ & $\begin{array}{c}\text { Density difference } \\
\rho_{\mathrm{d}}\left[\mathrm{kg} / \mathrm{m}^{3}\right]\end{array}$ & $\begin{array}{c}\text { Coefficient of compaction } \\
\mathrm{c}\left[\mathrm{m}^{-1}\right]\end{array}$ \\
\hline Cenozoic & 2700 & 1300 & 0.00035 \\
Upper Cretaceous & 2700 & 700 & 0.00027 \\
Lower Cretaceous & 2700 & 550 & 0.00025 \\
Jurassic & 2700 & 550 & 0.00025 \\
Triassic & 2700 & 450 & 0.00025 \\
Non-salt Upper Permian (Zechstein) & 2700 & 300 & 0.00025 \\
Lower Permian-pre-Permian & 2700 & 250 & 0.0003 \\
\hline
\end{tabular}


Table 3. Densities and magnetic susceptibilities of the layers of the 3D structural model.

\begin{tabular}{|c|c|c|c|c|c|c|}
\hline \multirow{2}{*}{ № } & \multirow{2}{*}{$\begin{array}{l}\text { Layer of the } \\
\text { 3D structural model }\end{array}$} & \multirow{2}{*}{ Predominant lithology } & \multicolumn{2}{|c|}{$\begin{array}{c}\text { Density } \\
\rho\left[\mathrm{kg} / \mathrm{m}^{3}\right]\end{array}$} & \multirow{2}{*}{$\begin{array}{c}\text { Dominant } \\
\text { magnetic } \\
\text { susceptibility } \\
\quad \chi_{\mathrm{m}}[\mathrm{SI}]\end{array}$} & \multirow{2}{*}{$\begin{array}{c}\text { Anomalous magnetic } \\
\text { susceptibility } \\
\chi_{\mathrm{m}}[\mathrm{SI}]\end{array}$} \\
\hline & & & 'Light' model & 'Heavy' model & & \\
\hline 1 & Sea water & - & 1030 & 1030 & 0 & - \\
\hline 2 & Cenozoic & Clastics & Eq. 2, Table 2 & Eq. 2, Table 2 & 0.0003 & - \\
\hline 3 & Upper Cretaceous & Carbonates, clastics & Eq. 2, Table 2 & Eq. 2, Table 2 & 0.0003 & - \\
\hline 4 & Lower Cretaceous & Clastics & Eq. 2, Table 2 & Eq. 2, Table 2 & 0.0003 & - \\
\hline 5 & Jurassic & Clastics & Eq. 2, Table 2 & Eq. 2, Table 2 & 0.0003 & - \\
\hline 6 & Triassic & Clastics, carbonates & Eq. 2, Table 2 & Eq. 2, Table 2 & 0.0003 & - \\
\hline 7 & Upper Permian (Zechstein) salt & Rock salt & 2300 & 2300 & -0.00001 & - \\
\hline 8 & $\begin{array}{c}\text { Non-salt Upper Permian } \\
\text { (Zechstein) }\end{array}$ & $\begin{array}{l}\text { Clastics, carbonates, } \\
\text { anhydrites }\end{array}$ & Eq. 2, Table 2 & Eq. 2, Table 2 & -0.00007 & - \\
\hline 9 & Lower Permian-pre-Permian & Clastics, carbonates & Eq. 2, Table 2 & Eq. 2, Table 2 & 0.0003 & - \\
\hline 10.1 & Middle-upper crustal intrusions & Intrusive rocks & 3000 & 3011 & $0.02-0.03$ & - \\
\hline 10.2 & Upper crustal magmatic rocks & $\begin{array}{l}\text { Gabbro to } \\
\text { anorthositic rocks }\end{array}$ & 2840 & 2842 & $0.0001-0.025$ & $0.03-0.09$ \\
\hline 11 & Low-density upper crustal layer & $\begin{array}{l}\text { Metasediments or } \\
\text { granite }\end{array}$ & $2630-2668$ & $2675-2727$ & $0.0001-0.02$ & 0.04 \\
\hline 12 & Regional upper crustal layer & Granite and gneiss & 2671 & 2729 & $0.0001-0.009$ & $0.015-0.07$ \\
\hline 13 & Eastern central North Sea rocks & $\begin{array}{l}\text { Granitoids and/or } \\
\text { gneiss }\end{array}$ & $2720-2793$ & $2777-2849$ & $0.0001-0.012$ & 0.025 \\
\hline 14 & Western central North Sea rocks & $\begin{array}{l}\text { Granitoids and/or } \\
\text { gneiss }\end{array}$ & $2784-2801$ & $2829-2860$ & $0.0001-0.019$ & $0.03-0.045$ \\
\hline 15 & $\begin{array}{l}\text { Middle crust of Laurentia and } \\
\text { Avalonia }\end{array}$ & $\begin{array}{l}\text { Granitoids and/or } \\
\text { gneiss }\end{array}$ & $2746-2761$ & $2780-2813$ & $0.00004-0.015$ & 0.025 \\
\hline 16 & Middle crust of Baltica & $\begin{array}{l}\text { Granitoids and/or } \\
\text { gneiss }\end{array}$ & 2747 & 2801 & $0.0001-0.01$ & $0.02-0.045$ \\
\hline 17 & Lower crust of Baltica & Metamorphic rocks & 2845 & 2926 & $0.0001-0.005$ & 0.028 \\
\hline 18 & High-density intracrustal layer & $\begin{array}{l}\text { Mafic granulites, } \\
\text { gabbros }\end{array}$ & 2930 & 2998 & $0.0001-0.018$ & $0.03-0.07$ \\
\hline 19 & High-density lower crustal layer & $\begin{array}{l}\text { Gabbros, high-grade } \\
\text { metamorphic rocks }\end{array}$ & 3055 & 3160 & $0.0001-0.005$ & $0.035-0.09$ \\
\hline 20.1 & Lithospheric mantle & Mainly peridotite & 3220 & 3324 & 0 & - \\
\hline 20.2 & Low-density lithospheric mantle & Mainly peridotite & $3204-3217$ & $3301-3316$ & 0 & - \\
\hline
\end{tabular}

the Upper Permian anhydrites is mainly restricted to the areas where the Upper Permian (Zechstein) rock salt is present forming, together with carbonates and partially clastics, the non-salt sequence (Fig. 6D) which is already characterised by a relatively small thickness (cf., Fig. 6, D). Unfortunately, the precise proportion of the Upper Permian anhydrites in the total thickness of the non-salt sequence is uncertain and, therefore, the thickness of anhydrites cannot be determined. Anhydrites have been mainly included into the non-salt layer and are at least partially present within the layer with the Upper Permian
(Zechstein) rock salt as a result of salt movements. Actually, the possible presence of anhydrites within the salt structures is one of the reasons why the density of the rock salt has been taken to be $2300 \mathrm{~kg} / \mathrm{m}^{3}$ which is higher than the density of pure rock salt. Unfortunately, there is no proper way to estimate the exact amount of anhydrites within the non-salt succession.

Finally, the highest depth-dependent densities have been assigned to the strongly compacted Lower Permian-prePermian sedimentary rocks according to the equation 
Table 4. Remanent magnetisation of crustal rocks for layer 10.1 (middle-upper crustal intrusions) and layer 10.2 (upper-crustal magmatic rocks) of the $3 D$ structural model.

\begin{tabular}{|c|c|c|c|c|c|c|c|}
\hline No & $\begin{array}{l}\text { Part of the layer of the } \\
\text { 3D-model }\end{array}$ & $\begin{array}{l}\text { Predominant } \\
\text { lithology }\end{array}$ & Age & Q-factor & $\begin{array}{c}\text { Remanent } \\
\text { declination } \\
\text { [degree] }\end{array}$ & $\begin{array}{c}\text { Remanent } \\
\text { inclination } \\
\text { [degree] }\end{array}$ & $\begin{array}{l}\text { Reference for } \\
\text { age, remanent } \\
\text { declination and } \\
\text { inclination }\end{array}$ \\
\hline 10.1 & $\begin{array}{l}\text { SE middle-upper crustal } \\
\text { intrusion }\end{array}$ & Intrusive rocks & Permian & 4 & 206 & -33 & $\begin{array}{l}\text { Torsvik et al. } \\
\text { (1997) }\end{array}$ \\
\hline 10.2 & $\begin{array}{l}\text { NE upper crustal mag- } \\
\text { matic rocks of the Jotun } \\
\text { Nappe Complex }\end{array}$ & $\begin{array}{l}\text { Gabbro or diorite } \\
\text { to ultrabasic } \\
\text { intrusions }\end{array}$ & $\begin{array}{l}\text { Caledonian } \\
(420-400 \mathrm{Ma})\end{array}$ & 0 and 1 & 359 & 52 & $\begin{array}{c}\text { Piper \& Poppleton } \\
(1990)\end{array}$ \\
\hline 10.2 & $\begin{array}{l}\text { Upper crustal magmatic } \\
\text { rocks of the Rogaland } \\
\text { Igneous Province }\end{array}$ & $\begin{array}{l}\text { Anorthosite, } \\
\text { norite, mangerite }\end{array}$ & $\begin{array}{c}\text { Post-Sveco- } \\
\text { norwegian } \\
(930-920 \mathrm{Ma})\end{array}$ & 3 and 7 & 293 & -64 & $\begin{array}{l}\text { McEnroe et al. } \\
\text { (1996); Brown \& } \\
\text { McEnroe (2004); } \\
\text { Olesen et al. } \\
\text { (2004) }\end{array}$ \\
\hline
\end{tabular}

(1) and compaction parameters in Table 2. The high degree of compaction for the pre-Permian sediments has been chosen assuming that these sedimentary rocks were already significantly compacted because they were deeply buried prior to being located at their present-day shallow position and/or were even locally exposed along the peripheries of the Meso-Cenozoic depocentres, mainly along the coast.

It is important to mention that, during the $3 \mathrm{D}$ density modelling, the density contrasts have been modelled to reproduce the observed gravity anomalies. In this case, the modelled densities can differ from the real absolute densities of rocks over a relatively wide range even if the modelled gravity response of the model fits the observed field. Besides, a single value of the P-wave seismic velocity can correspond to a range of densities rather than to a single density's value (e.g., Ludwig et al., 1970; Christensen \& Mooney, 1995). Moreover, there are some difficulties in using seismic velocities for constraining the density model due to limited data coverage, different resolution of the input data and the gridded ones that are actually characteristic for any regional- and lithospherescale study. In order to consider these uncertainties in densities of the crystalline crust and mantle, two endmember 3D density models have been obtained during the 3D modelling: a 'light' model with low densities and a 'heavy' one with high densities. The geometry of all layers of the model and densities of the sedimentary layers have been kept the same for both end-member models and, therefore, the difference between these models is only related to densities of the crystalline crust and mantle.

The upper-crustal densities of the crystalline rocks have been assigned by use of the Norwegian national petrophysical database (Olesen et al., 1993, 2010), which provides measured density and magnetic susceptibilities of the crystalline rocks which are exposed at the Earth's surface within the Norwegian mainland. The uppermost crystalline layer comprises gabbro to anorthositic rocks and, consequently, has a high density of 2840 and 2842 $\mathrm{kg} / \mathrm{m}^{3}$ in the case of the 'light' and 'heavy' models, respectively. A higher average density of $3000 \mathrm{~kg} / \mathrm{m}^{3}$ (the 'heavy' model density is $3011 \mathrm{~kg} / \mathrm{m}^{3}$ ) has been assigned to the magmatic intrusions that are locally present within the middle-upper crust of the study area. The density pattern of the upper crystalline crust indicates a decrease of average upper-crustal density from $2671 \mathrm{~kg} / \mathrm{m}^{3}$ (2729 $\mathrm{kg} / \mathrm{m}^{3}$ for the 'heavy' model) beneath the greater part of the model area to $2630 \mathrm{~kg} / \mathrm{m}^{3}\left(2675 \mathrm{~kg} / \mathrm{m}^{3}\right.$ for the 'heavy' model) beneath the Horda Platform. The middle crystalline crust of the northern North Sea and the adjacent continent is characterised by average densities of 2720 $2801 \mathrm{~kg} / \mathrm{m}^{3}\left(2777-2860 \mathrm{~kg} / \mathrm{m}^{3}\right.$ for the 'heavy' model). The assigned density for the lower crystalline crust of Baltica is $2845 \mathrm{~kg} / \mathrm{m}^{3}$ for the 'light' model and $2926 \mathrm{~kg} / \mathrm{m}^{3}$ for the 'heavy' one. On the other hand, the lowermost crustal layer is characterised by velocities which exceed 6.7-6.8 $\mathrm{km} / \mathrm{s}$. Therefore, the average density of this lower-crustal layer with the increased velocities has been taken as 3055 $\mathrm{kg} / \mathrm{m}^{3}$ in the case of the 'light' model and $3160 \mathrm{~kg} / \mathrm{m}^{3}$ for the 'heavy' one. In addition, a density of 2930 (2998) kg/ $\mathrm{m}^{3}$ has been assigned to the high-density middle-lower crust, the so-called high-density intracrustal layer. The assigned densities of the crystalline rocks (Table 3 ) are generally consistent with previous gravity studies within the same region (e.g., Lyngsie \& Thybo, 2007; Yegorova et al., 2007; Fichler et al., 2011; Maystrenko \& ScheckWenderoth, 2013; Nirrengarten et al., 2014) and are in the range of the empirical velocity-density relationship within the North Sea (Barton, 1986).

A marked velocity change from $6.9-7.1 \mathrm{~km} / \mathrm{s}$ within the lower crust to more than $8.0-8.3 \mathrm{~km} / \mathrm{s}$ within the uppermost mantle occurs at the Moho (Christie, 1982; Barton \& Wood, 1984; Iwasaki et al., 1994; Stratford et al., 2009; Kvarven et al., 2014). This prominent change in P-velocities points to a distinct increase of densities within the uppermost mantle compared to the lower crust. Considering the thermal state of the lithospheric 
mantle, a derived average density of the lithospheric mantle is $3220 \mathrm{~kg} / \mathrm{m}^{3}$ for the 'light' model and is $3324 \mathrm{~kg} /$ $\mathrm{m}^{3}$ for the 'heavy' one. Some atypical values of 3204-3217 $(3301-3316) \mathrm{kg} / \mathrm{m}^{3}$ have been assigned in places where the mantle low-velocity anomaly has been identified (Hejrani et al., 2015, 2017; Kolstrup et al., 2015; Köhler et al., 2015). Finally, an average density of $3160 \mathrm{~kg} / \mathrm{m}^{3}$ has been assigned to the uppermost asthenosphere in the case of the 'light' model and $3240-3265 \mathrm{~kg} / \mathrm{m}^{3}$ for the 'heavy' one. This density distribution is reflecting the thermal structure of the lithospheric mantle and neglects pressure effects, which only result in an additional density trend with depth. However, this linear increase does not affect the modelled gravity directly. Furthermore, seismic velocities are lower in the asthenosphere than within the overlying lithospheric mantle (e.g., Gregersen \& Voss, 2002; Shomali et al., 2006).

In the case of the lithosphere-scale 3D density model, a reference (background) density of $3200 \mathrm{~kg} / \mathrm{m}^{3}$ has been taken as an average density of the 'light' model and 3300 $\mathrm{kg} / \mathrm{m}^{3}$ for the 'heavy' model. Final values of densities given in Table 3 are obtained by 'Parameter Inversion' module in the IGMAS+ software which can automatically choose the most appropriate density within the predefined range of values for the selected layers in order to improve the manually obtained fit between the measured and modelled gravity fields. The latter is actually a reason why the density values values look like overprecise as for the regional-scale model.

The assigned values of the magnetic susceptibility are shown in Table 3. The upper-crustal magnetic susceptibilities are derived from the NGU petrophysical database (Olesen et al., 1993, 2010). During the 3D magnetic modelling, the average constant values for each crustal block have been assigned according to the locations of the sampling points. If information about the required property is absent within the NGU database, values obtained from the literature have been used. In particular, magnetic susceptibilities of the middle-lower crystalline crust are adopted from previously published estimations (e.g., Clark, 1997; Fichler et al., 2011; Ebbing \& Osmundsen, 2013). Sedimentary layers have been assumed to be lowmagnetic with the same magnetic susceptibility which is equal to 0.0003 SI. These low values of the magnetic susceptibility are in agreement with the total average value of 0.000288 SI according to results of well core measurements within the northern North Sea-Norwegian Sea area (Mørk et al., 2002). Negative values of the magnetic susceptibility have been assigned to Upper Permian (Zechstein) salt and Non-salt Upper Permian (Zechstein). The crystalline crust is characterised by a widely varying magnetic susceptibility ranging from less than 0.0001 to 0.09 SI (Table 3).

Finally, the remanent magnetisation of crustal rocks has been included into the model by assigning remanent declination, inclination and Königsberger ratio (Q-value - a ratio of remanent to induced magnetisation) to some rocks in order to fit the observed and modelled magnetic anomalies (Table 4). Measured values of remanent declination and remanent inclination have been used for the SE middle-upper crustal intrusion and the upper-crustal magmatic rocks of the Rogaland Igneous Province based on the values published by McEnroe et al. (1996), Brown \& McEnroe (2004) and Olesen et al. (2004). Consequently, remanent declination and inclination have been set to be $293^{\circ}$ and $-64^{\circ}$,respectively, for the rocks of the Rogaland Igneous Province and two Q-values of 3 and 7 have been chosen for these rocks. Brown \& McEnroe (2004) have shown that the Q-value of the EgersundOgna anorthosite varies from 3 to 148, indicating the strong variability of the intensity of the paleomagnetic field. According to 3D magnetic modelling, high values of the Königsberger ratio in the anorthosite of the Rogaland Igneous Complex represent rather local features. Brown \& McEnroe $(2004,2015)$ have also shown that parameters of the paleomagnetic field (declination and inclination) within the Rogaland Igneous Province can also vary quite strongly locally and, therefore, our chosen values are indicative numbers rather than the real ones. In addition, different values of remanent declination and inclination of the SE middle-upper crustal magmatic intrusion have been tested during the modelling based on the data published by Torsvik et al. (1997) and Olesen et al. (2004) with the preferable one according to Torsvik et al. (1997) (Table 4). Moreover, remanent declination and inclination have been used for the Jotun Nappe Complex according to measured values published by Piper \& Poppleton (1990). Remanent declination and inclination of the Jotun Nappe rocks have been chosen from the relatively wide range in Piper \& Poppleton (1990) to be $359^{\circ}$ and $52^{\circ}$, respectively (Table 4). Two Q-values for the magnetically anomalous Jotun Nappe Complex have been taken to be 0 and 1 .

Furthermore, an anomalous total magnetisation of some lower-crustal blocks cannot be explained by suitable values of the induced magnetisation alone, implying an influence of remanent magnetisation as well. However, there are no data for remanent declination and inclination for the lower-crustal rocks due to their very deep location. Accordingly, Q-values have been considered for the remanent magnetisation of the anomalous, highdensity, lower-crustal rocks (Q-values have been taken to be $0.5,1.0,2.0$ and 3.0). In this case, the direction of the remanent magnetisation has been assumed to be similar to the configuration of the present-day magnetic field and, therefore, declination and inclination of the presentday geomagnetic reference field have not been changed for these anomalous lower-crustal blocks during the 3D magnetic modelling. 


\section{Methodology of density and magnetic modelling}

The 3D density and magnetic modelling have been performed by use of the IGMAS+ software (the Interactive Gravity and Magnetic Application System; Götze, 1978; Götze \& Lahmeyer, 1988; Schmidt \& Götze, 1998; Götze \& Schmidt, 2010). Prior to the modelling, a triangulation between structural depth maps is applied along pre-defined vertical slices to obtain the geometry of the model in $3 \mathrm{D}$. The geometrical approximation for the layers of the $3 \mathrm{D}$ model is determined by a complex $3 \mathrm{D}$ mesh which includes multiple polyhedra with triangulated planes between the top and the base of each layer and constant densities are assigned to these polyhedra. Finally, the integral gravity or magnetic effect of all triangulated polyhedra gives the total gravity or magnetic effect of the 3D structural model.

The procedure of 3D gravity and magnetic modelling is based on interactive changes of the geometry and density or magnetic properties of the layers. In particular, the shapes of the layers/bodies were modified manually during the modelling, whereas the density values and magnetic properties were chosen both manually and automatically. Automatic inversions of density and magnetic properties within a chosen range of values have been applied at a final stage of the modelling to improve the fit between the modelled and the observed potential fields. The $3 \mathrm{D}$ density modelling itself was carried out by changes of the geometry and densities along $169 \mathrm{E}-\mathrm{W}$ oriented vertical slices through the $3 \mathrm{D}$ structural model of the northern North Sea System and adjacent areas (Fig. 9A). The distance between these 2D working planes is the same as the horizontal resolution of the model, which is $4 \mathrm{~km}$.

The 3D magnetic modelling, on the other hand, was performed along $84 \mathrm{E}-\mathrm{W}$-oriented vertical slices through the $3 \mathrm{D}$ structural/density model (Fig. 9B). The number of vertical slices has been reduced due to a necessity to include more than 190 additional crustal blocks into the model with different magnetic properties in order to obtain a proper fit between the observed and modelled magnetic fields. In contrast, the $3 \mathrm{D}$ density model has only 22 layers (Table 3 ). However, the presence of more than 190 blocks requires a colossal effort in modifying their geometries and, therefore, the number of the vertical slices had to be reduced. In this case, the distance between $2 \mathrm{D}$ working planes is equal to $8 \mathrm{~km}$, that is two times greater than the horizontal resolution of the model.
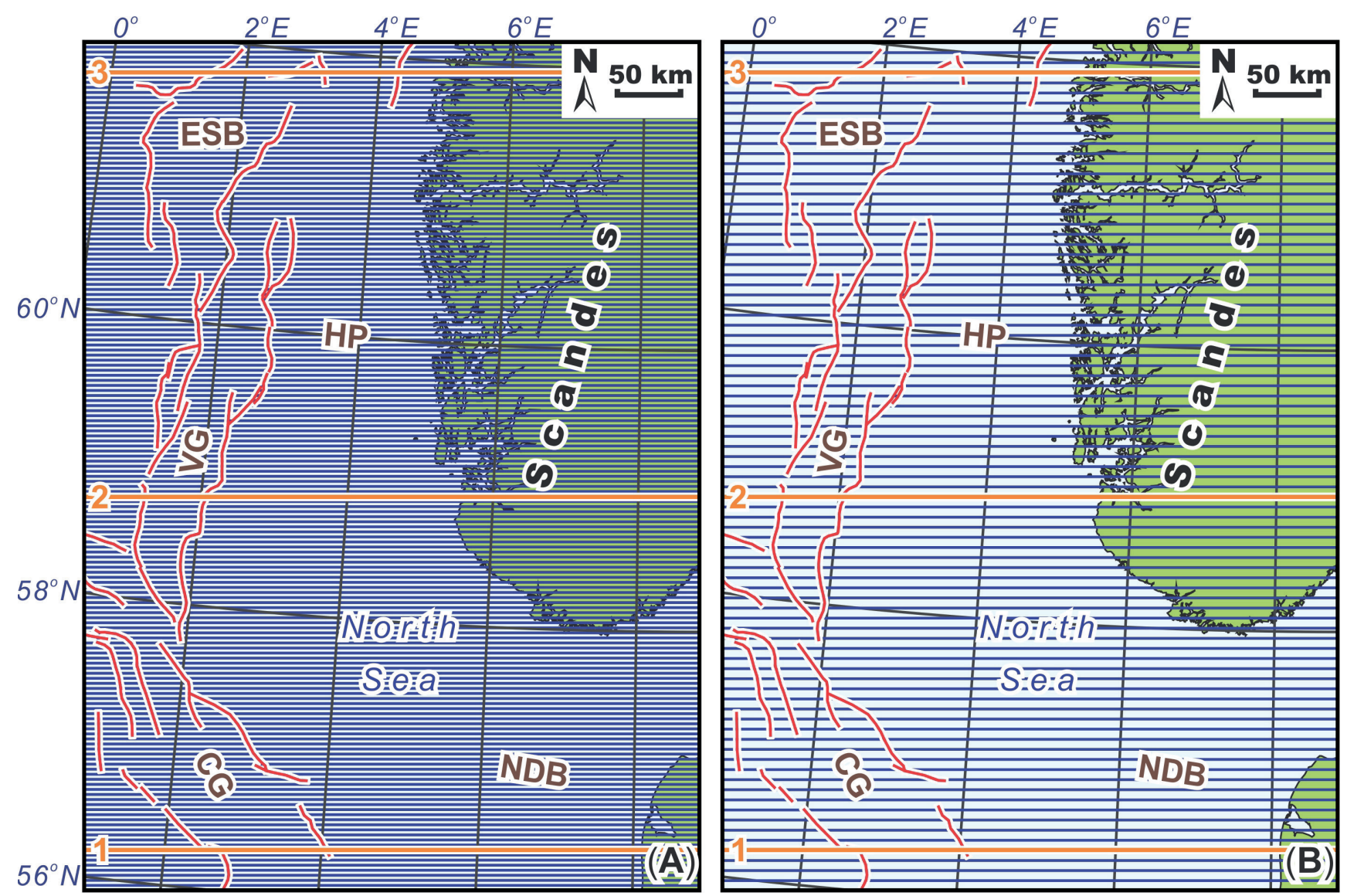

Figure 9. (A) Location of the $2 D$ vertical slices through the $3 D$ density model (blue lines). (B) Location of the $2 D$ vertical slices through the $3 D$ magnetic model (blue lines). Three selected slices are highlighted by bold orange lines and numbering. Faults are from Sigmond (2002). 
The horizontal resolution has been kept to around $4 \mathrm{~km}$ in the $\mathrm{E}-\mathrm{W}$ direction, and a decrease of the resolution in the N-S direction does not strongly affect the regionalscale features of the crystalline crust within the study area. The $2 \mathrm{D}$ working slices are parallel to each other and cross the most important gravity and magnetic anomalies and the major structural elements of the study area to avoid potential artefacts due to $3 \mathrm{D}$ triangulation between the slices. Additionally, the 3D model has been laterally extended in all directions, exceeding the actual model area. Thereby, the major structural features have been prolonged to the extended parts of the $3 \mathrm{D}$ structural model to avoid boundary effects.

Furthermore, in order to consider the depth-dependent densities in accordance with exponential functions (1-6), the sedimentary layers of the $3 \mathrm{D}$ model have been additionally voxelised with the horizontal voxel size of $4 \mathrm{~km}$ and the vertical one of $250 \mathrm{~m}$.

An inherent non-uniqueness of the used approach has been described in detail by Maystrenko et al. (2017). Here, we would only like to point out that numerous density/magnetic and structural models can be responsible for the same modelled gravity/magnetic field. In our study, these limitations of the method have been considerably reduced by taking into account the lateral influence of the layers in three dimensions and by use of additional constraining data. It is also important to mention that the uncertainties in geometry and densities/ magnetic properties increase with depth, mostly due to the decreasing resolution of the input data and objective uncertainties in the compositions of the deep layers.

In addition, the chosen grid resolution of the model played an important role. In the case of our lithospherescale model, the horizontal resolution has been set at 4 $\mathrm{km}$ in order to consider the complex shape of the Upper Permian (Zechstein) salt which forms a variety of salt structures and is characterised by lower densities compared with the surrounding sedimentary rocks. During the $3 \mathrm{D}$ magnetic modelling, the horizontal resolution of the model has been reduced to $8 \mathrm{~km}$ in the N-S direction due to a less important contrast between magnetic susceptibilities of salt and sedimentary rocks compared to the density. In this case, any large changes in thickness/depth of the model's layers at distances less than 4 $\mathrm{km}$ cannot be correctly reproduced in our model. The latter leads to some local large misfits between the original input data and the used gridded data. This is especially important for the sedimentary layers where major changes in the geometry of the layers, especially for the Upper Permian (Zechstein) salt, occur at distances shorter than $4 \mathrm{~km}$. The difference in resolution between the original input and used gridded data is less important for the deep crust because the resolution of the input data is already relatively low at that level.

\section{Results}

The results of the 3D density modelling demonstrate that the obtained gravity responses of the 'light' and 'heavy' $3 \mathrm{D}$ density models (Fig. 10A, C) are in good agreement with the long-wavelength component of the observed gravity field (Fig. 8A) over the area under consideration. The difference between observed and modelled gravity (Fig. $10 \mathrm{~B}, \mathrm{D})$ demonstrates that some local gravity anomalies have not been reproduced during the $3 \mathrm{D}$ density modelling. Most of these residual misfits are in the range of \pm $5 \mathrm{mGal}$. Locally, some short-wavelength misfits between the observed and the calculated gravity anomalies are more than $\pm 25 \mathrm{mGal}$. On the other hand, these shortwavelength local misfits do not have a marked impact on the regional gravity field and, therefore, do not strongly influence the structure of the study area at the regional scale.

According to the results of the 3D magnetic modelling, the modelled induced and remanent magnetic anomalies (Fig. 11A), calculated for the final 3D model, are also in good agreement with the long-wavelength component of the upward-continued observed magnetic field (Fig. 8C). In addition, the modelled induced magnetic anomalies are also shown in Fig. 11B, allowing us to see a difference in the case where remanent magnetisation is not considered during the modelling. This difference between modelled induced and remanent magnetic anomalies and only the modelled induced ones is mostly related to the intensity of positive magnetic anomalies M1-M8 and a broad negative anomaly over the northwestern part of the Norwegian-Danish Basin (cf. Fig. 11A, B).

It has to be mentioned that some of the short-wavelength local misfits are locally characterised by high amplitude in the case of the magnetic modelling. On the other hand, these misfits do not have a strong impact on the regionalscale component of the magnetic field which has been mostly reproduced during the modelling. Moreover, some of these high-amplitude misfits are related to the presence of strong remanent magnetisation which varies over small distances and, therefore, cannot be properly considered in this regional study.

For a geological purpose, the crystalline crust of the study area has been subdivided into several layers during the $3 \mathrm{D}$ gravity modelling. For the 3D magnetic modelling, layers obtained from the 3D density modelling have been partially subdivided into several blocks with different magnetic properties in order to reproduce the observed magnetic field. According to this approach, fitting of the observed and modelled magnetic fields has been accomplished mainly by changes of magnetic susceptibilities which were kept in the range of measured values according to the NGU petrophysical database (Olesen et al., 1993, 2010). Some anomalous zones have been modelled to be cross-cutting several layers in cases where it is 

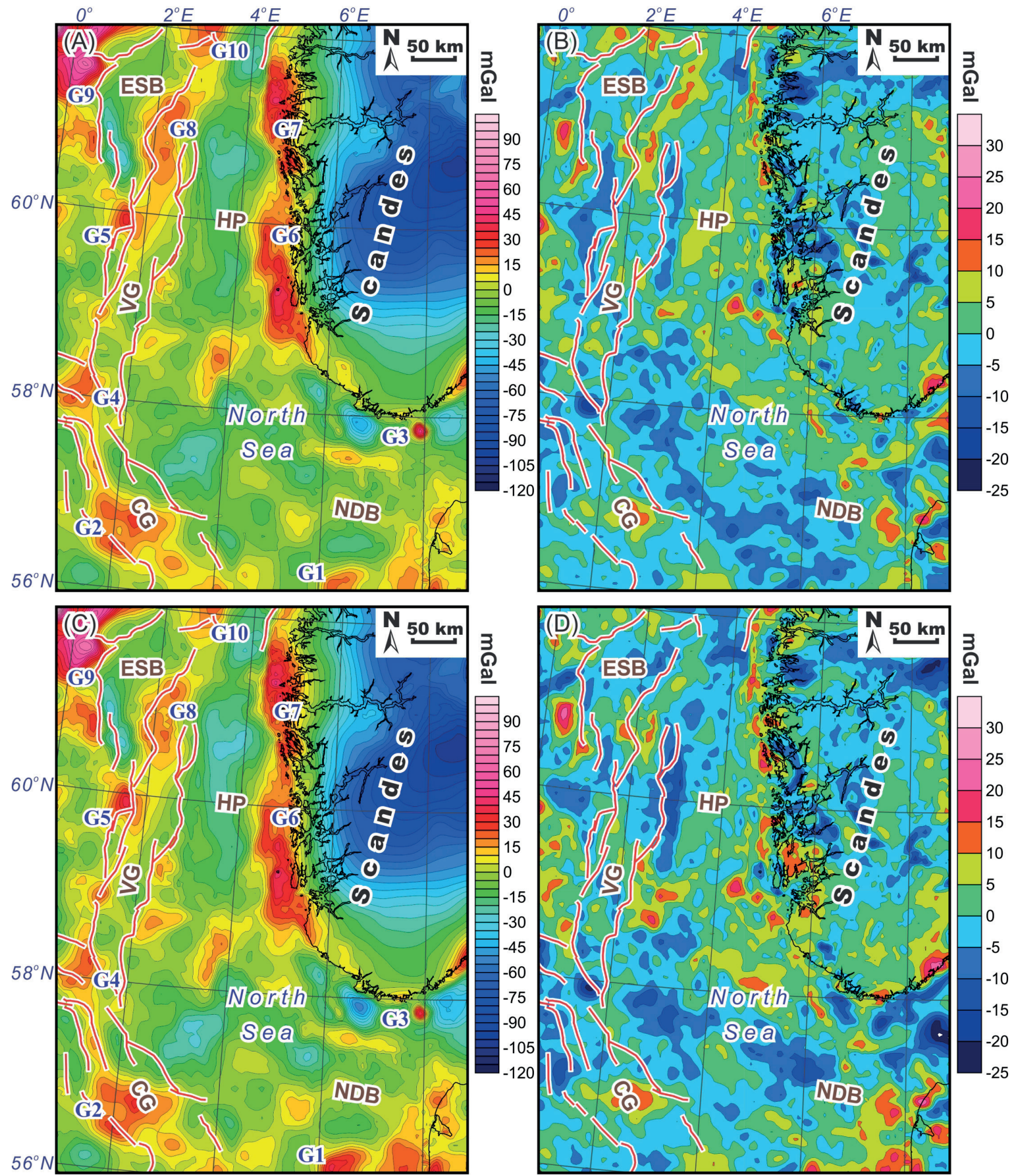

Figure 10. 'Light' $3 D$ density model: (A) modelled gravity anomalies and (B) residual gravity map, demonstrating the difference between the modelled gravity field (Fig. 10A) and the observed one (Fig. 8A). 'Heavy' 3D density model: (C) modelled gravity anomalies and (D) residual gravity map, demonstrating the difference between the modelled gravity field (Fig. 10D) and the observed one (Fig. 8A). G1-G10 - names of the important positive magnetic anomalies offshore.

required to obtain a good fit between the observed and the modelled magnetic fields. Locally, results of the 3D magnetic modelling have been used to improve the 3D density model. Consequently, the final density-derived crustal layers based on results of the 3D density/magnetic modelling are shown in map view where magnetically anomalous parts of these layers are highlighted on additional maps (Figs. 12-17). 

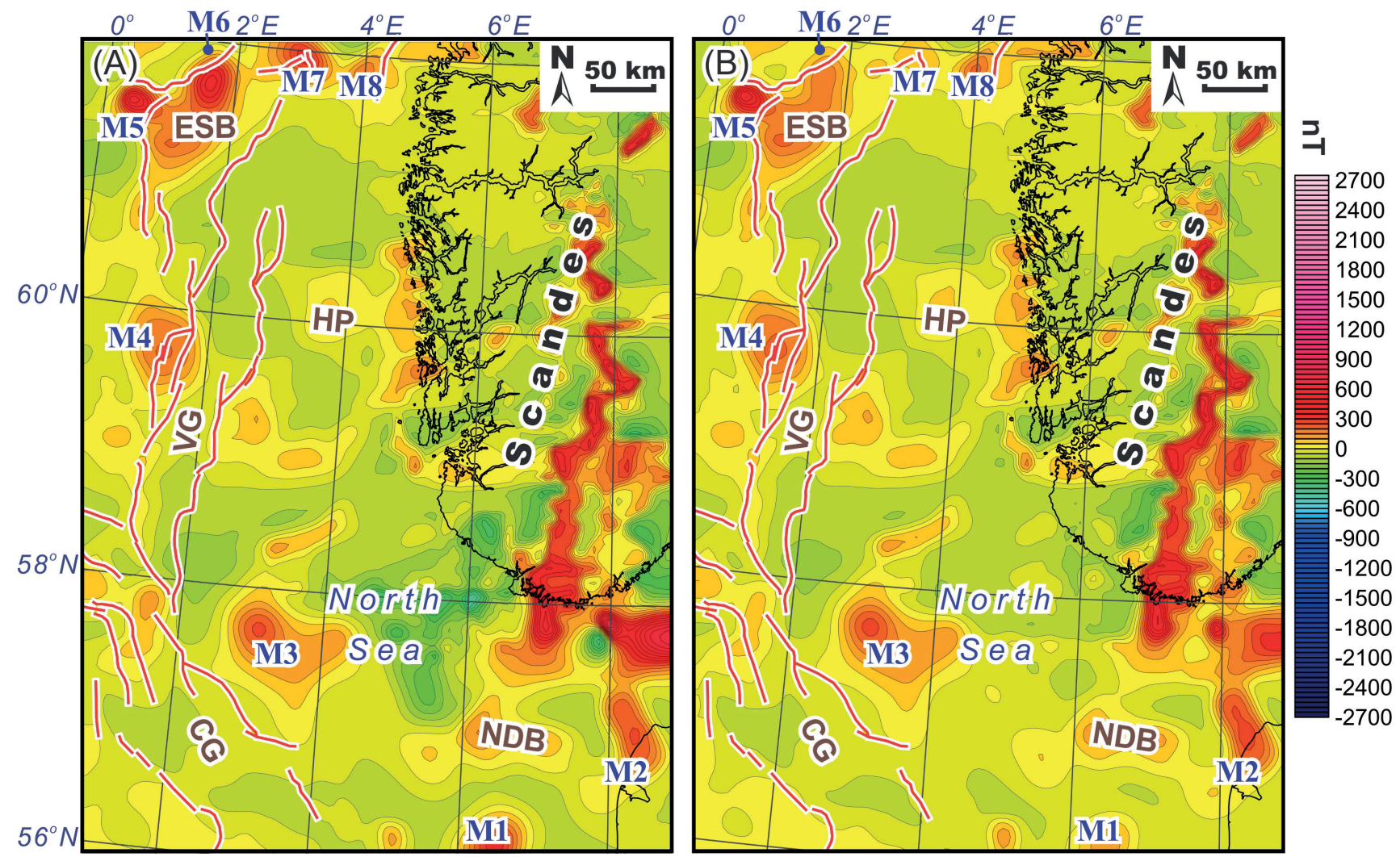

Figure 11. (A) Modelled induced and remanent magnetic anomalies. (B) Modelled induced magnetic anomalies. M1-M8 - names of the important positive magnetic anomalies offshore.

The modelled upper crystalline crust includes four layers: middle-upper-crustal intrusions (layer 10.1), uppercrustal magmatic rocks (layer 10.2), low-density uppercrustal rocks (layer 11) and regional upper-crustal layer (layer 12) (Table 3). Within the uppermost crystalline crust, two local layers have been included in the 3D model. These layers are represented by shallow magmatic intrusions (layer 10.1; Fig. 12A) and gabbroic to anorthositic rocks (layer 10.2; Fig. 12B, C). Only two middle-upper intrusions have been determined during the gravity modelling (Fig. 12A). The first intrusion, related to gravity anomaly G3, is located near the southern coast of Norway and the second one, associated with anomaly G9 is modelled within the northwestern flank of the East Shetland Basin (the northwestern corner of the model area). On the other hand, this does not mean that there are no other intrusive bodies within the crust of the study area. Some of the intrusions can be smaller than the horizontal resolution of the 3D structural model, whereas the larger intrusive complexes are partially represented by the high-density middle-lower-crustal layers which are described below. The southeastern upper-crustal intrusion near the southern coast of Norway (Fig. 12A) has a very strong magnetic effect, and the character of the related anomalous magnetic field implies a strong contribution from the remanent magnetisation. The age of this intrusion is most likely Permian according to the best fit between the modelled and observed magnetic fields (cf., Figs. 8C \& 11A), if the Permian component of the paleomagnetic field is taken from Torsvik et al. (1997). There, the magnetic field is characterised by the presence of very intensive, interconnected, positive and negative magnetic anomalies. These anomalies coincide spatially with the rounded positive gravity anomaly (cf., Fig. 8A, B $\& \mathrm{C}$ ), indicating that both gravity and magnetic anomalies originate from the same source.

The above-described intrusion is surrounded by uppercrustal magmatic rocks (Fig. 12B) which are part of the gabbroic to anorthositic complex (layer 10.2). This upper-crustal magmatic layer is partially associated with gravity anomalies G6 and G8 (cf., Figs. 8A, 10A \& 12B). These rocks are actually well mapped at the surface along the western coast of Norway (e.g., Bergen Arc System) and within the northwestern part of the model where the Jotun Nappe is located (Sigmond, 2002). The modelled thickness of the Caledonian Jotun Nappe (2700-4500 m) is in agreement with the previous attempt at gravity modelling in this area (Skilbrei, 1990). The well mapped Bergen Arc System has a rounded shape (Fig. 11B) and consists of several Caledonian nappes which contain mainly anorthosites, gneisses, amphibolites, diorites, gabbros and metabasalts (Ragnhildstveit \& Helliksen, 1997). Towards the west from the southeastern intrusion, a broad zone 


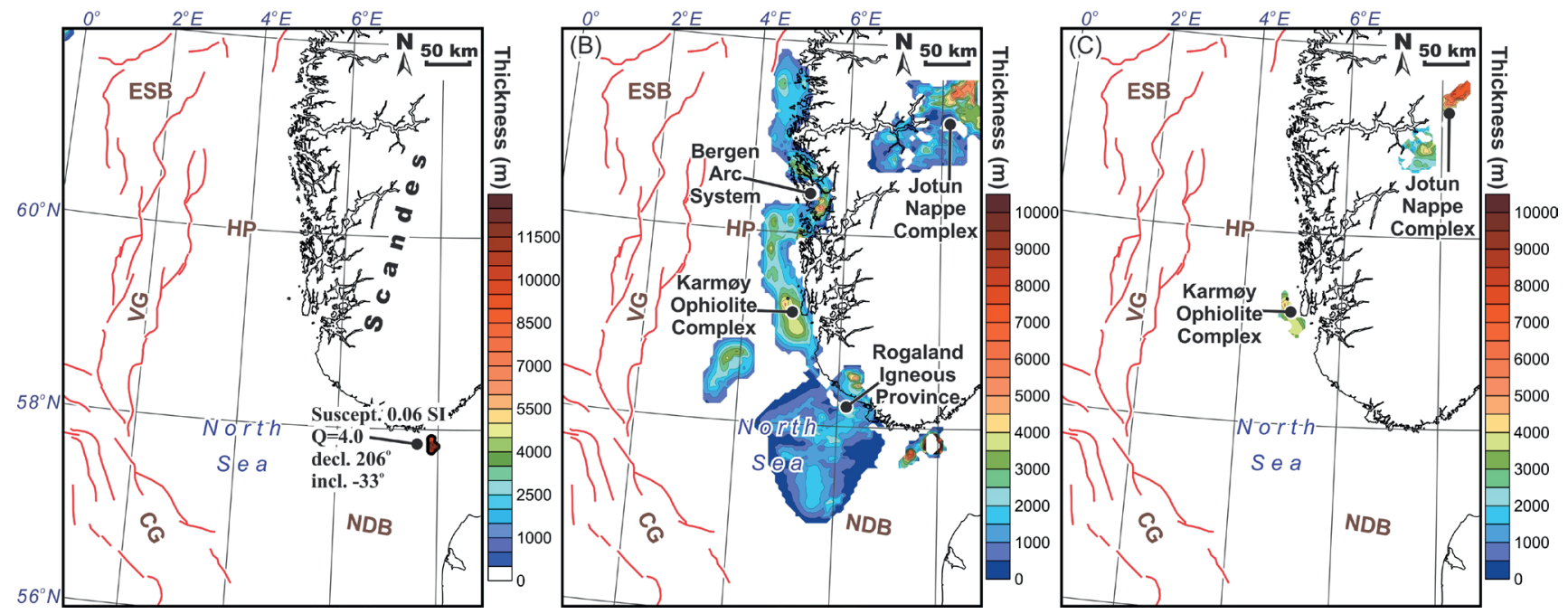

Figure 12. Upper crystalline crust. (A) Thickness of the middle-upper crustal intrusions (layer 10.1). Thickness of the upper crustal magmatic rocks (layer 10.2): (B) the main body of the layer and (C) blocks with increased magnetic susceptibility.

of upper-crustal magmatic rocks (mostly anorthosites) is interpreted to be related to the Rogaland Igneous Province and is characterised by the previously mentioned large variations in Q-values onshore SW Norway (Brown \& McEnroe, 2004, 2015) that are difficult to interpret. On the other hand, including the remanent magnetisation ( $\mathrm{Q}$ is equal to 3 and 7 , declination $293^{\circ}$ and inclination $64^{\circ}$; Olesen et al., 2004) of these rocks gives us an opportunity to model the broad magnetic low within the northwestern part of the Norwegian-Danish Basin (see the negative anomaly to the east of the positive anomaly M3 in Figs. 8B, C \& 11A). According to the 3D magnetic modelling, the origin of this negative magnetic anomaly is mostly related to a difference in direction and intensity between the present-day Earth's magnetic field and the paleomagnetic one. In addition, two anomalous blocks of upper-crustal magmatic rocks with increased magnetic susceptibilities have been included into the 3D model (Fig. 11C). The first one is located near the island of Karmøy and is most likely structurally and tectonically related to the Karmøy Ophiolite Complex. The second one is defined within the northeastern part of the Jotun Nappe Complex (Fig. 11C) and can be represented by metaplutonic rocks.

The third upper-crustal layer is modelled beneath the Horda Platform (layer 11; Fig. 13A). This layer is locally 9-15 km thick on average and the greater part of this layer is characterised by a low density (the 'light' density is $2630 \mathrm{~kg} / \mathrm{m}^{3}$ and the 'heavy' one is $2675 \mathrm{~kg} / \mathrm{m}^{3}$ ) which can correspond to either metasediments or granite. The low-density upper-crustal layer is characterised by the presence of two zones with increased magnetic susceptibility (Fig. 13B). This variable magnetic susceptibility can indicate that the lithological composition of the layer may differ from the rest of the layer beneath the central part of the Horda Platform and within the northern part of the layer.
The next upper-crustal layer (layer 12; Fig. 13C) is characterised by a regional distribution and has an ordinary upper-crustal density of $2671 \mathrm{~kg} / \mathrm{m}^{3}$ (the 'heavy' model density $2729 \mathrm{~kg} / \mathrm{m}^{3}$ ). This upper-crustal layer is thickest beneath the Norwegian mainland, implying that the total crystalline crust is more dense within the North Sea where thick sedimentary successions are known to occur. The regional upper-crustal layer is characterised by the presence of several magnetically anomalous blocks within the mainland (Fig. 13D). Most of these blocks with increased magnetic susceptibility are related to granitic and/or granodioritic rocks which are mapped at the surface according to geological data (Sigmond, 2002). These granitic blocks are mostly represented by granite plutons of the late-Sveconorwegian granitoid series. Actually, there is a very good correlation between the position of the positive magnetic anomalies and mapped granitic bodies. On the other hand, geological mapping of these granitic/granodioritic blocks is already partially based on the interpretation of the magnetic data. In any case, these magnetically anomalous granites are exposed at the surface in many places in South Norway where they have been well studied (e.g., Sylvester, 1998; Bolle et al., 2003; Van der Auwera et al., 2011). Based on the 3D magnetic modelling, these anomalous granitic blocks are characterised by almost $\mathrm{N}-\mathrm{S}$, regionally continuous, subvertical zones with increased magnetic susceptibility, varying from 0.03 SI to 0.06 SI on average. The high values of magnetic susceptibility are taken from the NGU petrophysical database (Olesen et al., 1993, 2010) and, therefore, represent measurements on rocks sampled from the areas where these granites are exposed. These high values of magnetic susceptibilities are also supported by detailed studies of specified granitic plutons, for instance, the Holum granite is characterised by a magnetic susceptibility which varies in the range 0.03-0.09 SI with average values around $0.06 \mathrm{SI}$ (Bolle et al., 2003). Locally, these granites with increased 

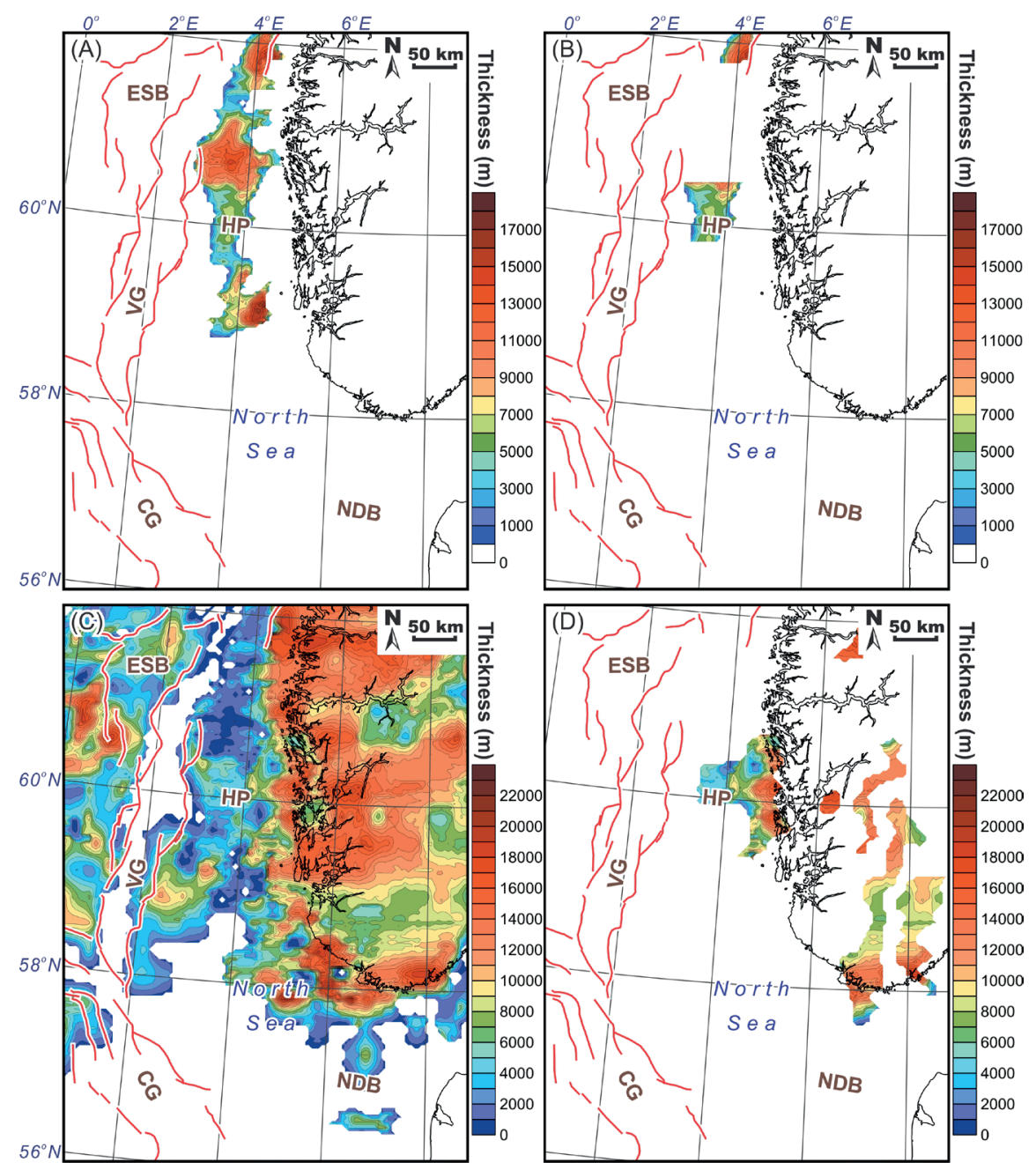

Figure 13. Upper crystalline crust. Thickness of the low-density upper crustal layer (layer 11): (A) main body of the layer and (B) blocks with increased magnetic susceptibility. Thickness of the regional upper crustal layer (layer 12): (C) main body of the layer and (D) blocks with increased magnetic susceptibility.

magnetic susceptibility are covered by low-magnetic granitic or granodioritic gneisses (Sigmond, 2002). The intensity of the continuous magnetic anomalies (Fig. 8B, C) implies that the thickness of the overlying granitic or granodioritic gneisses is relatively small and, therefore, they have not been included into this regional model in places where the gneisses are known to be very thin and overlie anomalous late-Sveconorwegian granitoid rocks. An additional large anomalous block has been included into the model near the Bergen Arc System beneath the middle part of the Horda Platform (Fig. 13D). This block can be at least partially related to a known granitic/ granodioritic body, the Løvstakken granite, near Bergen, which has a relatively high radiogenic heat production (Maystrenko et al., 2015b; Pascal \& Rudlang, 2016).

The modelled middle crust of the study area contains four layers with comparable densities (Table 3): eastern central North Sea rocks (layer 13), western central North Sea rocks (layer 14), middle crust of Laurentia and Avalonia (layer 15) and the middle crust of Baltica (layer 16). Prior to the $3 \mathrm{D}$ density modelling, the preliminary position of the relatively wide suture zone between Avalonia, Laurentia and Baltica within the central part of the North Sea had been determined by Lyngsie et al. (2006) and Lyngsie \& Thybo (2007). These authors proposed that this crustal suture is located beneath the Central and Viking grabens. Accepting the location of this suture zone, two middle-crustal domains, in addition to the crystalline crust of Baltica, Avalonia and Laurentia, have been included in the model within the central part of the North Sea.

A narrow zone of middle-crustal rocks with densities of $2720-2793 \mathrm{~kg} / \mathrm{m}^{3}$ (the 'heavy' model densities $2777-2849$ $\mathrm{kg} / \mathrm{m}^{3}$ ) has been included in the model beneath the eastern parts of the Viking and Central grabens (layer 13; Fig. 14A, B) and can be represented mainly by granitoids or gneisses. Towards the west, another narrower zone of middle crustal rocks has been integrated into the model beneath the western part of the Viking and Central grabens (layer 14; Fig. 14C, D). These western central North Sea rocks have the highest average densities $\left(2784-2801 \mathrm{~kg} / \mathrm{m}^{3}\right.$ for the 'light' model and $2829-2860$ 


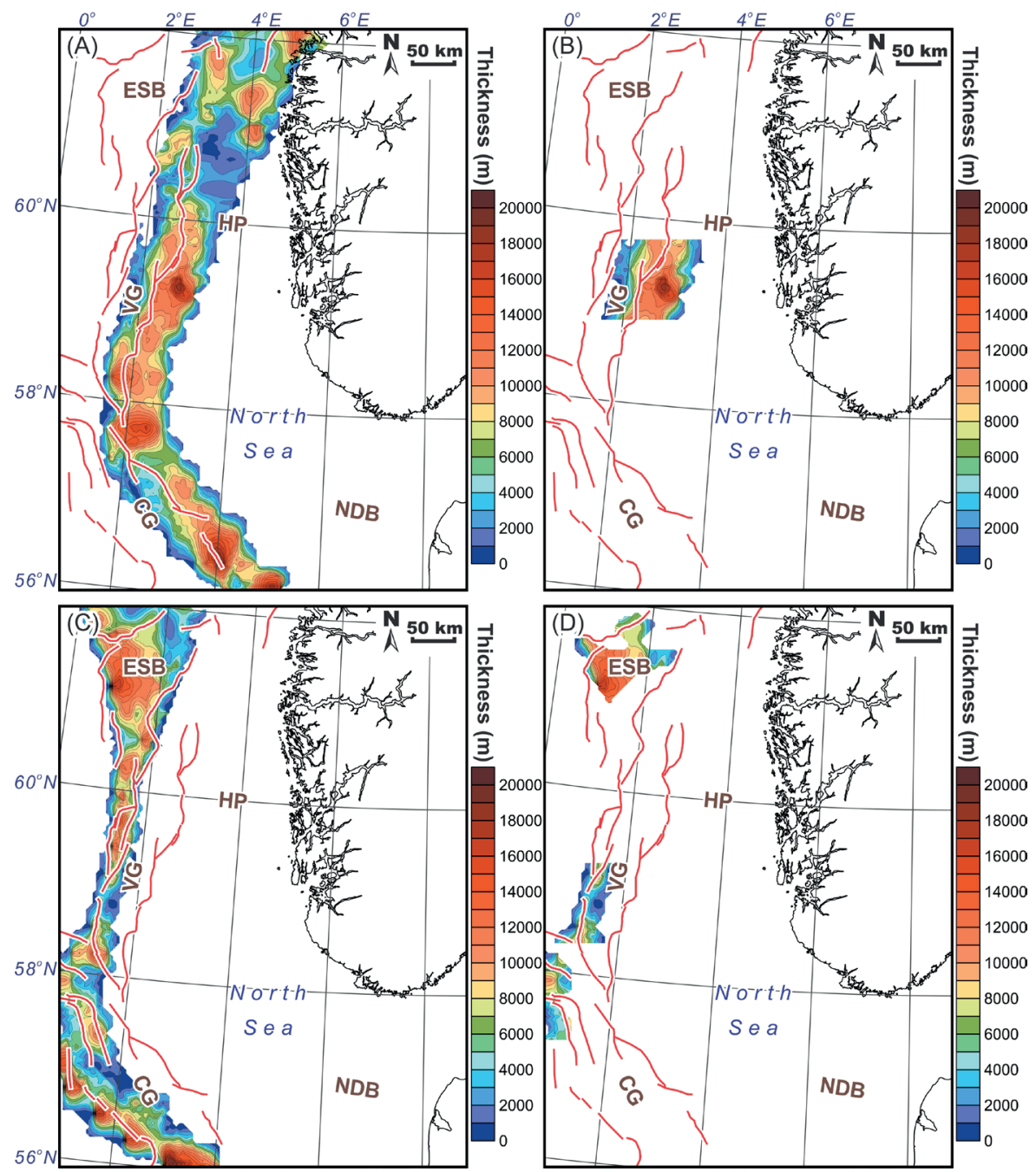

Figure 14. Middle crystalline crust. Thickness of the eastern central North Sea rocks (layer 13): (A) main body of the layer and (B) blocks with increased magnetic susceptibility. Thickness of the western central North Sea rocks (layer 14): (C) main body of the layer and (D) blocks with increased magnetic susceptibility.

$\mathrm{kg} / \mathrm{m}^{3}$ for the 'heavy' one) that have been assigned to the middle-crustal layers (Table 3). The thickness of the layer is locally more than $14 \mathrm{~km}$. The middle crystalline crust of Laurentia and Avalonia (layer 15; Fig. 15A) has been defined in the westernmost part of the model area. The thickness of the middle crust of Laurentia and Avalonia is around $15 \mathrm{~km}$ on average, and locally reaches more than $20 \mathrm{~km}$.

According to the 3D magnetic modelling, the anomalous middle crust of the western Central North Sea and Laurentia (Figs. 14B, D \& 15B) is partially responsible for the origin of two positive magnetic anomalies, called M4 and M5 in Figs. 8C and 10. Actually, the magnetic anomalies M4 and M5 coincide with the positive gravity anomalies (cf., Fig. 8A, B) which are caused by a density contrast between sediments and crystalline rocks, and density contrasts between crustal layers with different densities along the western marginal faults of the East Shetland Basin and the Viking Graben. There, magnetically anomalous parts of the middle crust of the Central North Sea together with the magnetically anomalous blocks of the lower-crustal layers, form the anomalous zone near the major western boundary faults of the East Shetland Basin and the Viking Graben.

The largest middle-crustal layer is represented by the middle crust of Baltica (layer 16; Fig. 15C). This layer has a density of $2747 \mathrm{~kg} / \mathrm{m}^{3}\left(2801 \mathrm{~kg} / \mathrm{m}^{3}\right.$ for the 'heavy' model) and, therefore, most likely consists of granitoids or gneisses. The layer is thickest beneath the mainland, reaching more than $20 \mathrm{~km}$ locally. The magnetically anomalous middle crust of Baltica (Fig. 15D) is not characterised by such high magnetic susceptibilities as in the previously described middle-crustal layers. One of the anomalous zones is located beneath the southern part of the Horda Platform (Fig. 15D) and can correspond to relatively dense granitic rocks. Based on the $3 \mathrm{D}$ magnetic analysis, the NW-SE-trending magnetic anomaly M2 is caused by a similarly shaped block of the middle crust of Baltica with increased magnetic susceptibility (cf., Figs. 8B, C \& 15D). This middle-crustal block could pos- 

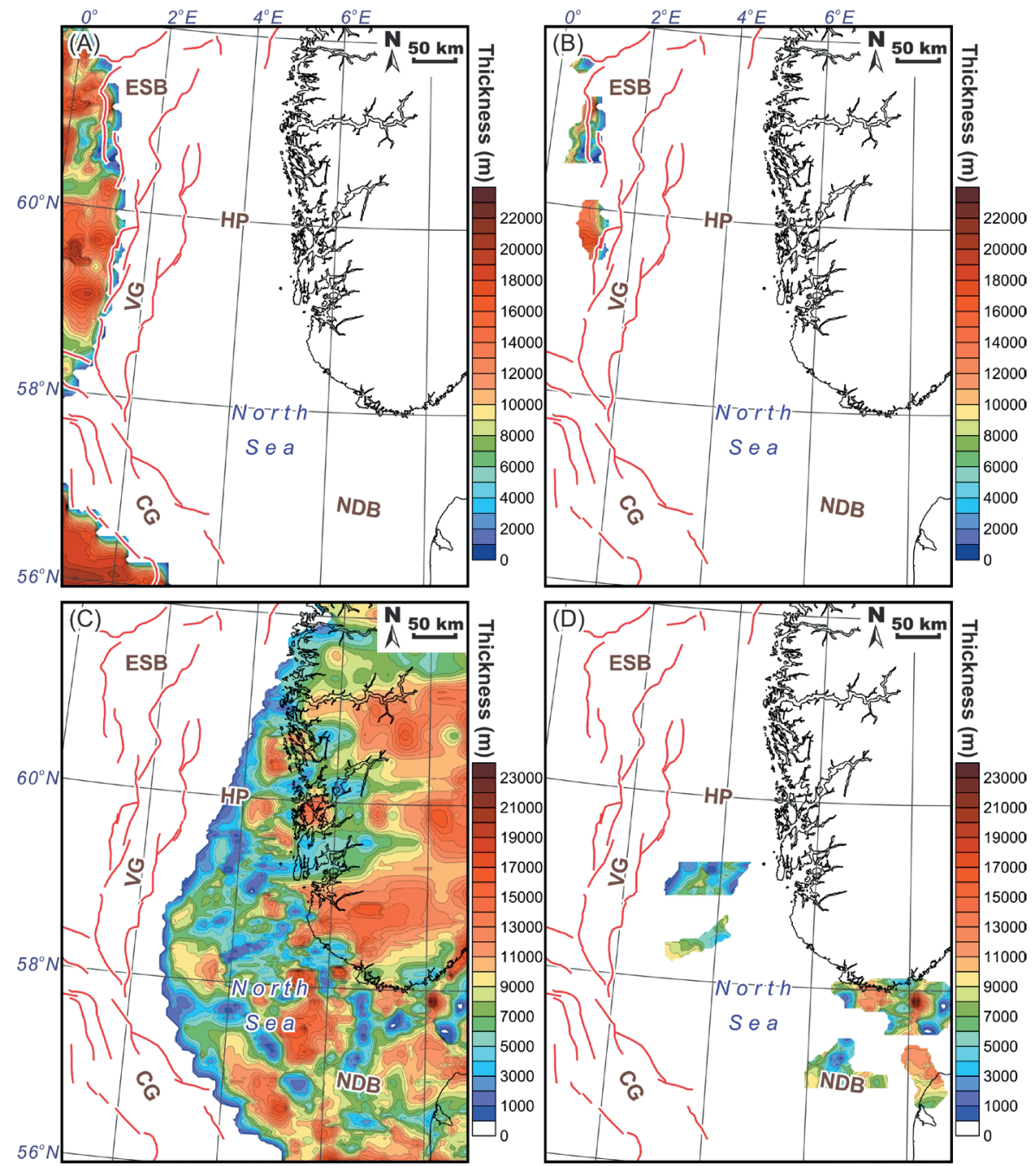

Figure 15. Middle crystalline crust. Thickness of the middle crust of Laurentia and Avalonia (layer 15): (A) main body of the layer and (B) blocks with increased magnetic susceptibility. Thickness of the middle crust of Baltica (layer 16): (C) main body of the layer and (D) blocks with increased magnetic susceptibility.

sibly represent a southern extension of the magnetically anomalous granitic and/or granodioritic rocks, inferred for the regional upper-crustal layer (Fig. 13B) but with a higher density.

The modelled lower crust consists of three layers: the lower crust of Baltica (layer 17), a high-density intracrustal layer (layer 18) and a high-density lower-crustal layer (layer 19) (Table 3). The first layer is the lower crust of Baltica (layer 17; Fig. 16) which thins markedly from 6-10 km within the Precambrian crustal domain of southern Norway to less than $1 \mathrm{~km}$ beneath the central part of the North Sea. During the 3D magnetic modelling, none significant magnetic anomalies have been attributed to this layer.

A high-density intracrustal layer has been modelled within the lower-middle crystalline crust with an average density of $2930 \mathrm{~kg} / \mathrm{m}^{3}$ for the 'light' model or 2998 $\mathrm{kg} / \mathrm{m}^{3}$ for the 'heavy' one (layer 18; Fig. 17A, B) to fit the observed and calculated gravity in addition to a high- density lower crust (layer 19; Fig. 17C, D). The prominent feature of this layer is the narrow area of thickening beneath the Viking Graben which is partially related to the gravity anomaly G8 (cf., Figs. 8A, 10B \& 17A). There, this intracrustal layer is characterised by thickened zones which are elongated NE-SW and restricted to the axial part of the graben structure. Moreover, thickening of this intracrustal layer with increased density is partially associated with the gravity anomalies G2, G4, G5 and G9. The largest anomalous block of the high-density intracrustal layer (Fig. 17B) is responsible for a wide, positive, magnetic anomaly M3 (Figs. 8B, C \& 11) which is located between the northern part of the Central Graben and the northwestern part of the Norwegian-Danish Basin. The remaining blocks with increased magnetic susceptibility are located along the western marginal faults of the East Shetland Basin and the Viking Graben, as well as beneath the triple junction of the Central and Viking grabens and the Moray Firth Basin (Fig. 17B). 


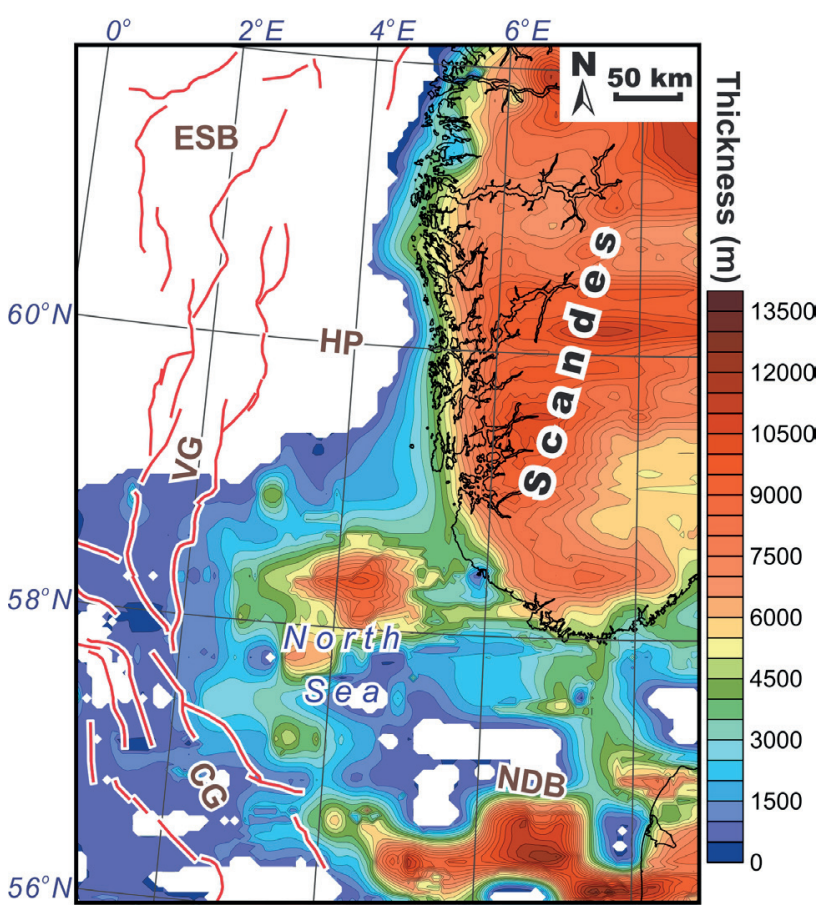

The deepest lower-crustal layer is the high-density lowercrustal layer (layer 19; Fig. 17C) which has been assigned an average density of $3055 \mathrm{~kg} / \mathrm{m}^{3}$ in the 'light' model and $3160 \mathrm{~kg} / \mathrm{m}^{3}$ in the 'heavy' model (Table 3), and corresponds to the lowermost crustal layer where observed P-wave velocities exceed $6.7-6.8 \mathrm{~km} / \mathrm{s}$. This layer thickens considerably beneath the Norwegian-Danish Basin (to more than $15 \mathrm{~km}$ ) and the eastern part of the East Shetland Platform (more than $10 \mathrm{~km}$ ). The rest of the model area is characterised by a relatively thin, high-density, lower crust which is characterised by an almost constant thickness (thinner than $5 \mathrm{~km}$ ) beneath the continent. The magnetically anomalous part of this layer contributes to the origin of positive magnetic anomalies M4 and M5 (cf., Figs. 8B, C, 11A \& 17D). Moreover, blocks of this layer with increased magnetic susceptibility are

Figure 16. Lower crystalline crust. Thickness of the lower crust of Baltica (layer 17).
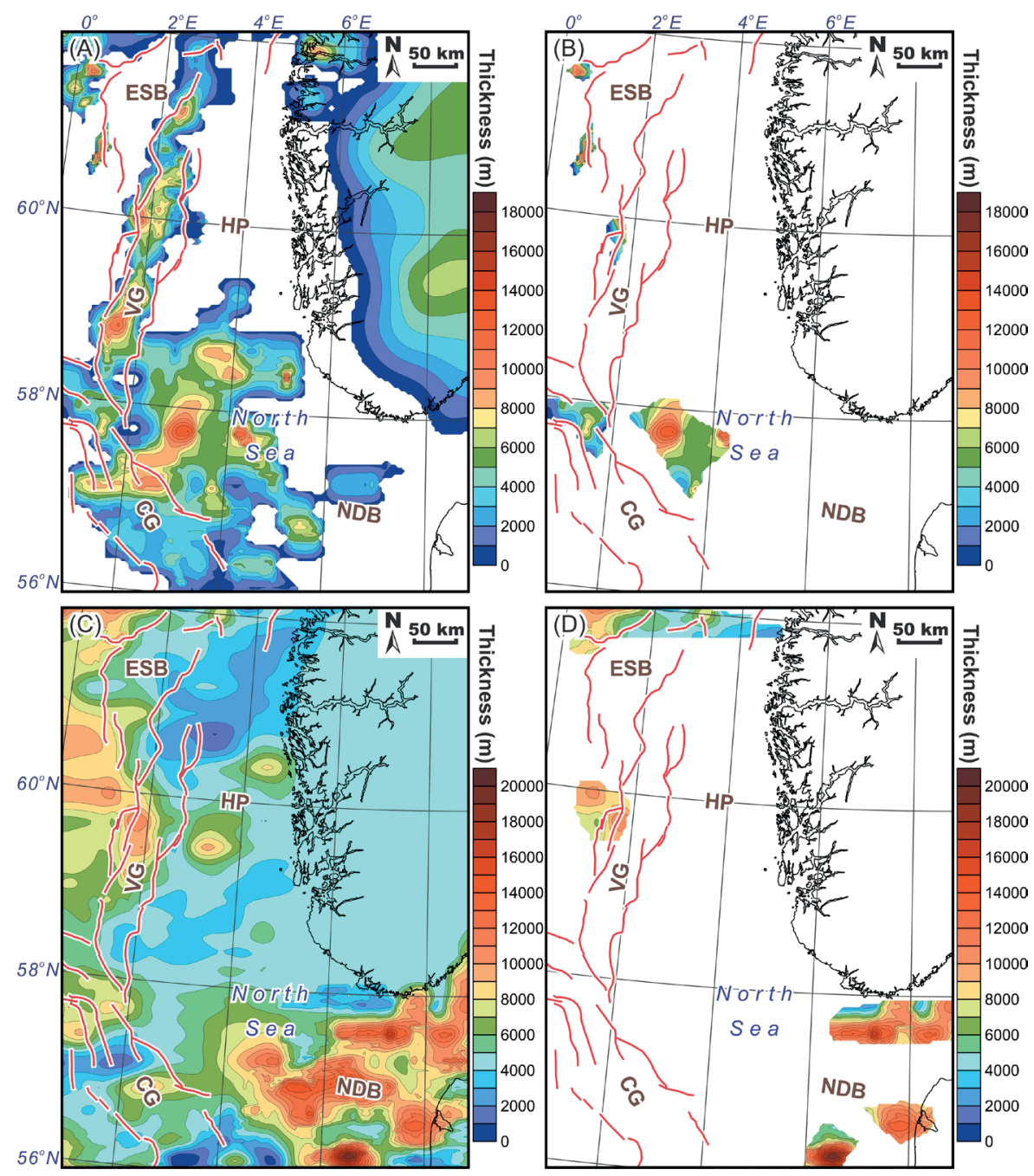

Figure 17. Lower crystalline crust. Thickness of the high-density intracrustal layer (layer 18): (A) main body of the layer and (B) blocks with increased magnetic susceptibility. Thickness of the high-density lower-crustal layer (layer 19): (C) main body of the layer and (D) blocks with increased magnetic susceptibility. 


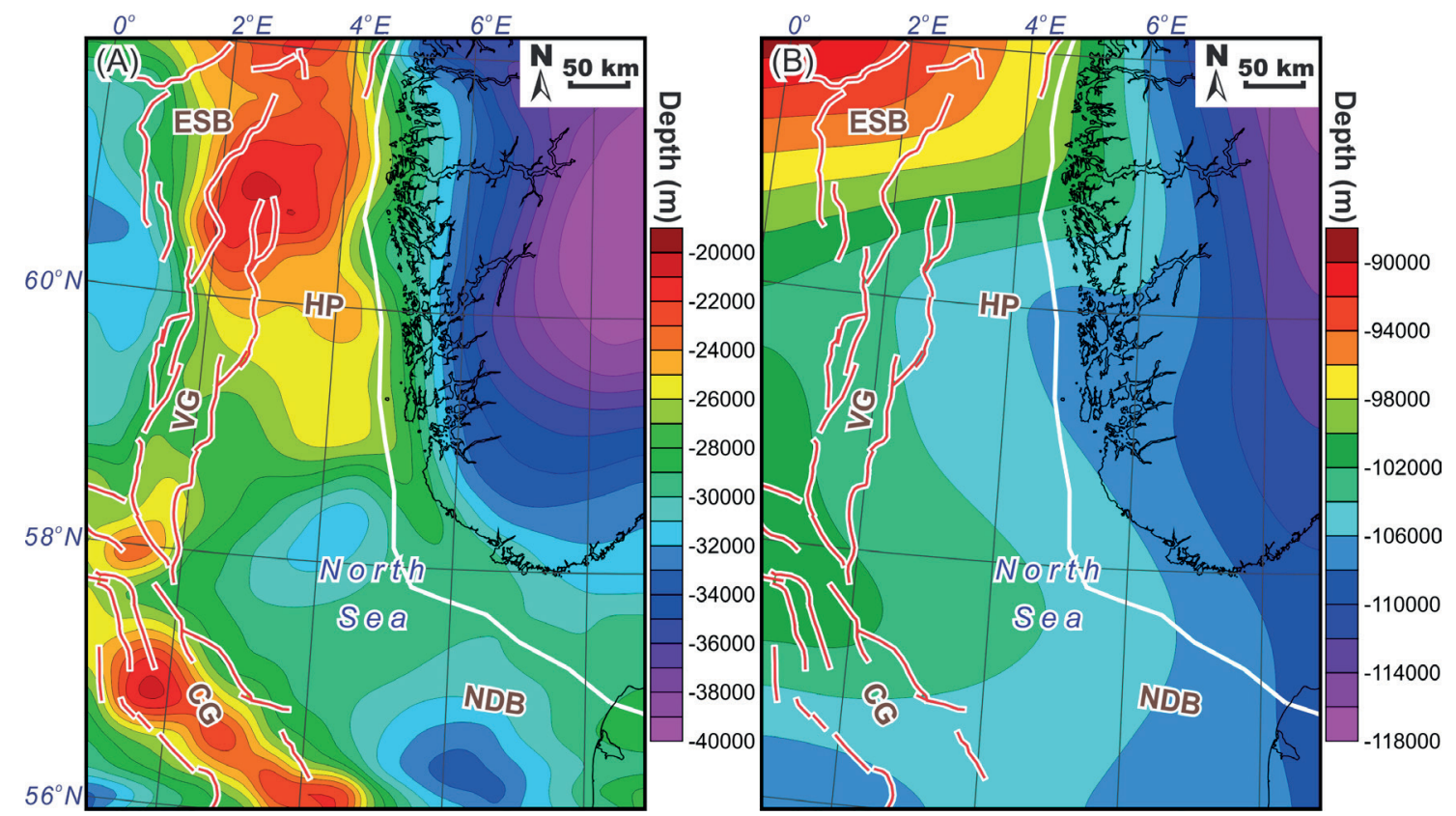

Figure 18. (A) Resulting depth to Moho and (B) resulting depth to the lithosphere-asthenosphere boundary. White line outlines the low-density mantle beneath $S W$ Norway and adjacent offshore areas.

responsible for the positive magnetic anomalies observed both to the west and to the east of the round-shaped negative anomaly located over the southwest intrusion. Magnetic anomaly $\mathrm{M} 1$ is also possibly originating from inside this layer. Within the northernmost part of the model area, a chain of positive magnetic anomalies M6, M7 and M8 can be seen (Fig. 8B, C). These magnetic anomalies have been either partially or almost wholly attributed to the high-density lower crustal layer (Fig. 17D). The reason for this is that there is not enough room for anomaly M7 to have originated in the middle or upper crust due to the strong thinning of the crystalline crust beneath the depositional centre of the East Shetland Basin. Sources for anomalies M6 and M8 have also been partially modelled to be in the same layer based on the proximity of these anomalies to anomaly M7 and similarities in the magnetic patterns of all three anomalies.

The obtained Moho topography (Fig. 18A) and depth to the base of the lithosphere (Fig. 18B) correlate clearly with the major tectonic units of the study area. Both boundaries are located deeply beneath the continent, at more than $116 \mathrm{~km}$ depth in the case of the lithosphereasthenosphere boundary and at more than $39 \mathrm{~km}$ depth in the case of the modelled Moho. Furthermore, the Moho is prominently uplifted to $20 \mathrm{~km}$ beneath the Central and Viking grabens, whereas the lithosphere-asthenosphere boundary is relatively shallow beneath the central western part of the model area. On the other hand, the base of the lithosphere is less than $90 \mathrm{~km}$ deep (Fig. 18B), showing an uplift of the lithosphere-asthenosphere boundary towards the Cenozoic oceanic domain within the Atlantic Ocean. It is important to note that the litho- spheric mantle beneath the continent and adjacent offshore areas has been assigned a lower density (the 'light' model densities are $3204-3217 \mathrm{~kg} / \mathrm{m}^{3}$ and the 'heavy' model densities are $3301-3316 \mathrm{~kg} / \mathrm{m}^{3}$ ) compared to the ordinary lithospheric mantle with a density of $3220 \mathrm{~kg} /$ $\mathrm{m}^{3}$ (the 'heavy' model density is $3324 \mathrm{~kg} / \mathrm{m}^{3}$ ) within the rest of the model area. This has been done in order to match the modelled gravity field with the observed one. The modelled lateral extent of the low-density lithospheric mantle is more or less clear with some local uncertainties according to the $3 \mathrm{D}$ density modelling and is marked by the white line in Fig. 18A, B. However, the vertical extent of this atypical lithospheric mantle is very uncertain due to the fact that if the density contrast between the ordinary lithospheric mantle and the lowdensity one is increased, the thickness of the low-density mantle will become smaller and vice versa. Consequently, the obtained configuration of the low-density lithospheric mantle is rather a first-order approximation of the required lower density material beneath the crust of SW Norway.

Based on the results of the regional-scale 3D density and magnetic modelling, the input structural data have been refined in terms of the lithosphere-scale 3D structural model. The output 3D model (Fig. 19) includes twentytwo layers from the base of the lithosphere to the present-day Earth's surface (Table 3).

The cross-sectional view of the structure across the major structural units is shown along three selected 2D vertical slices through the 3D model (Figs. 20-22) in order to highlight some of the main structural features 


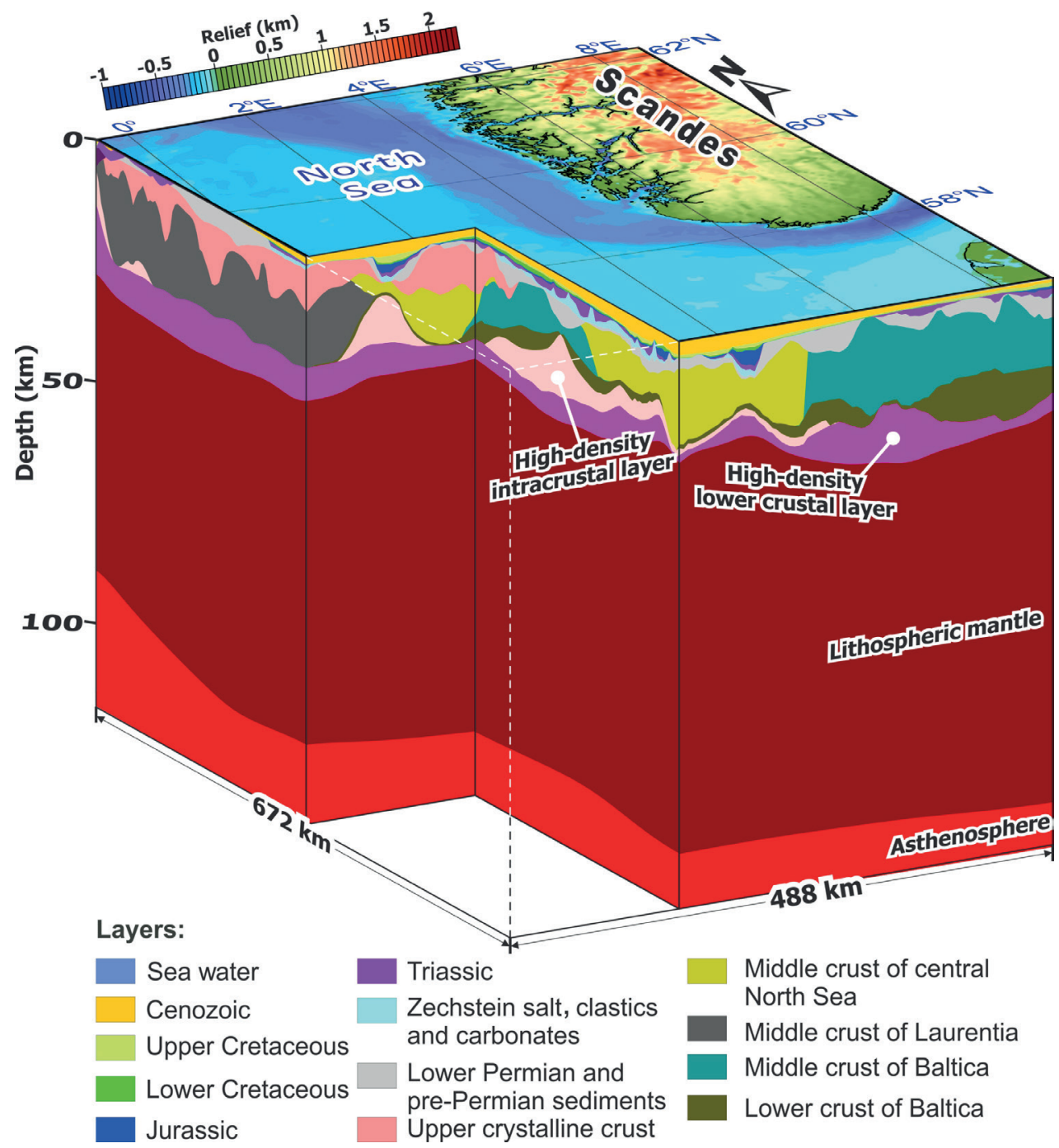

Figure 19. Lithosphere-scale 3D structural model of the northern North Sea and adjacent areas of the continent (four times vertically exaggerated).

of the study area. E-W-oriented vertical slice 1 (Fig. 20) is located within the southern part of the study area (Fig. 9), crossing the Central Graben and the southern part of the Norwegian-Danish Basin. Along this line (Fig. 20), a marked uplift of the Moho is observed beneath the Central Graben. To the east, a remarkable thickening of the high-density lower-crustal layer occurs beneath the Norwegian-Danish Basin. In addition, this slice shows a mosaic structure of the crystalline crust in the vicinity of the Central Graben where two middle-crustal blocks have been introduced between the Precambrian crust of Baltican origin in the east and the inferred crustal domain of Avalonia to the west. Vertical slice 1 shows also the origin of positive magnetic anomaly M1. The main point is that this magnetic anomaly M1 coincides spatially with a positive gravity anomaly G1 (cf., Fig. 20A, $\mathrm{B}$ or Fig. 8A, B). A remarkable thickening of the highdensity lower-crustal layer is the main source for the positive gravity anomaly G1. Therefore, the most logical interpretation is to suggest that the interconnected magnetic anomaly M1 also has the same origin as the thickened high-density lower-crustal layer.
Line 2 (Fig. 21) runs across the southern parts of the Viking Graben and the Horda Platform (Fig. 9). Vertical slice 3 crosses the pronounced magnetic highs over the magnetically anomalous late-Sveconorwegian granitic and/or granodioritic blocks within the upper crust of southern Norway. In general, it can be inferred that the upper crystalline crust has a very complex structure along this slice according to the jagged character of the observed magnetic curve. However, some local structural details of geology have not been included into the $3 \mathrm{D}$ model due to the limited resolution of this regional study. The prominent, wide, magnetic low in the middle of slice 2 (Fig. 21) has been modelled to be related to the low-magnetic crystalline crust. This slice is also interesting in terms of the different origins of two positive gravity anomalies along this line. The western, low-amplitude, gravity high is related to an integral gravity effect of a marked thickening of the high-density intracrustal layer beneath the Viking Graben and a density contrast between the crystalline rocks within the uplifted western flank and thick sedimentary cover along the steeply dipping marginal fault of the western Viking Graben. On the 

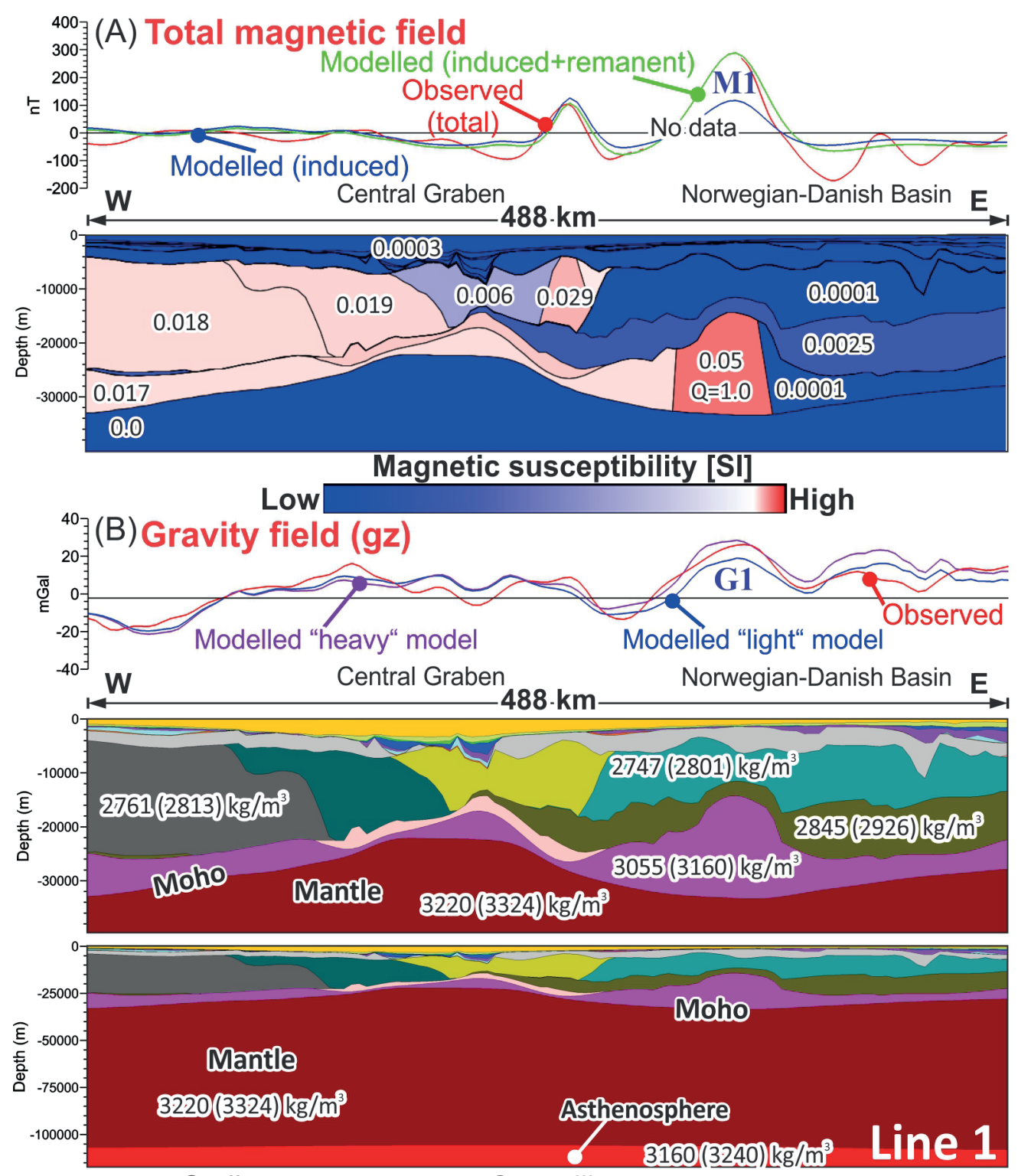

Sediments:

1. Sea water;

2. Cenozoic;

3. Upper Cretaceous;

4. Lower Cretaceous;

5. Jurassic;

6. Triassic;

7. Zechstein salt;

8. Zechtein clastics and carbonates;

9. Lower Permian and pre-Permian sedimentary rocks.
Crystalline crust:

$3160(3240) \mathrm{kg} / \mathrm{m}^{3}$ Line 1

10.2. Gabbro to anorthositic rocks;

11. Metasediments or granite;

12. Upper crustal layer;

13. Eastern middle crust of the central North Sea;

14. Western middle crust of the central North Sea;

15. Middle crust of Laurentia;

16. Middle crust of Baltica;

17. Lower crust;

18. High-density intracrustal layer;

19. High-density lower crustal layer.

Figure 20. Selected vertical slice 1 through the 3D structural model in Fig. 19. (A) slice through the 3D magnetic model and (B) vertical slice through the 3D density model. The location of this slice is shown in Fig. 9. Layer numbering is the same as in Table 3. The 'light' model density is without brackets and the 'heavy' model density is in brackets. 


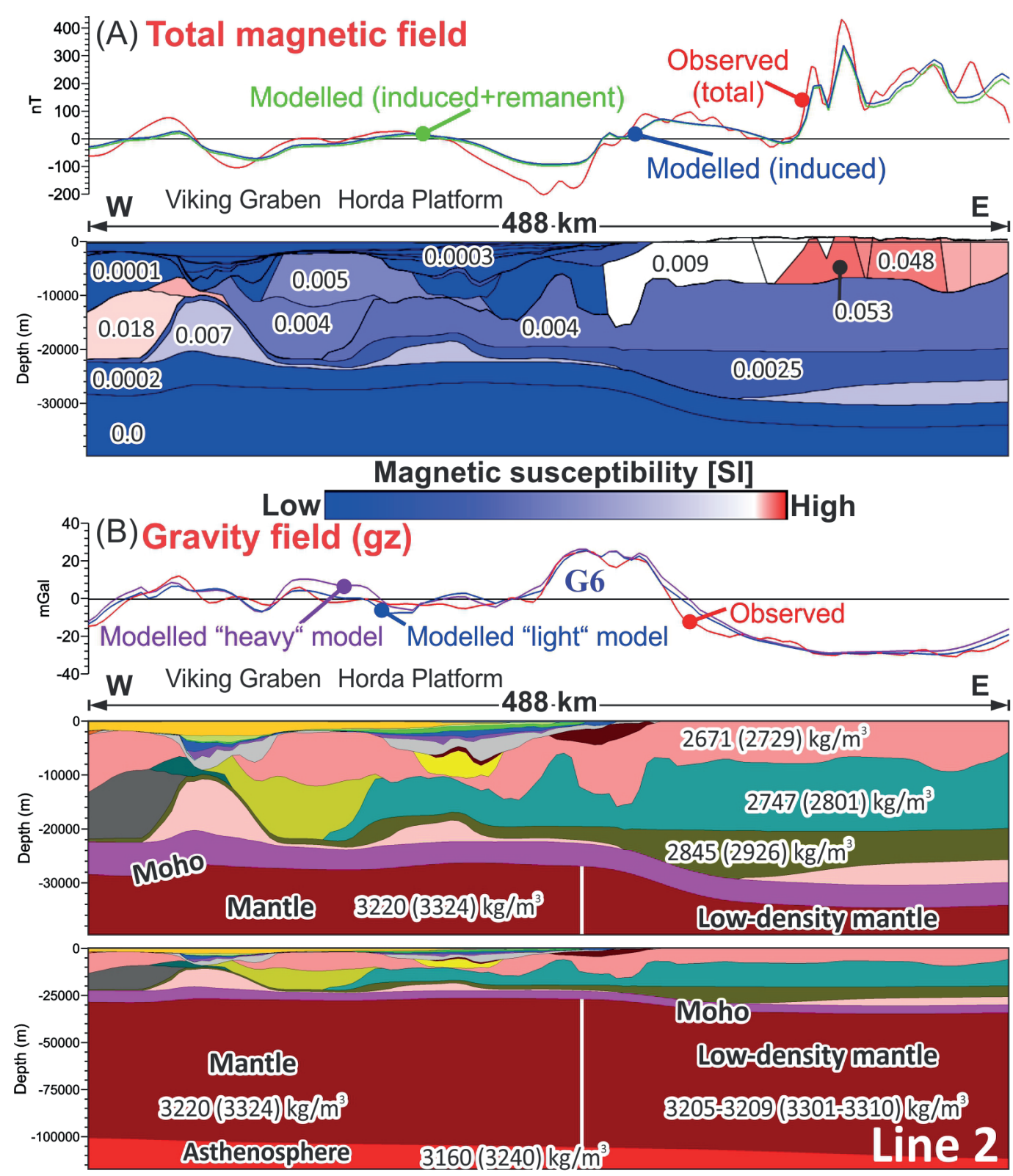

Figure 21. Selected vertical slice 2 through the 3D structural model in Fig. 19. (A) slice through the 3D magnetic model and (B) vertical slice through the 3D density model. The location of this slice is shown in Fig. 9. The 'light' model density is without brackets and the 'heavy' model density is in brackets.

other hand, the second gravity anomaly (anomaly G6) is mostly associated with the near-surface, high-density, gabbroic-anorthositic rocks which are well mapped along the southwestern coast of Norway (e.g., Sigmond, 2002) and, in addition, it is related to an uplift of the crystalline rocks towards the Norwegian mainland.

Towards the north (Fig. 9), Line 3 is interesting in terms of the origin of three positive magnetic anomalies M6, M7 and M8 (Fig. 22A). As already mentioned, all these three anomalies are at least partially originating from the high-density lower-crustal layer. Moreover, magnetic anomaly M6 is also associated with middle-upper-crustal blocks with high magnetic susceptibility according to structural features of the crystalline crust in this part of the study area (Fig. 22A) where the middle-upper crust is thick enough to have anomalous blocks associated with anomaly M6. On the other hand, the lower-crustal origin of the positive magnetic anomaly M7 is supported by the presence of the extremely thin middle-upper crust beneath the sedimentary depocentre of the East Shetland Basin to the north of this vertical slice. There, the thickness of the middle-upper crystalline crust is locally less than $3 \mathrm{~km}$. Therefore, the thickness of the middle-upper crust is most likely not large enough to include the magnetically anomalous crustal blocks associated with the observed high-amplitude magnetic anomaly M7. It has to be mentioned that the origin of the observed anomalies M6, M7 and M8 can be also attributed to the upper mantle rocks because the Curie isotherm for the domi- 

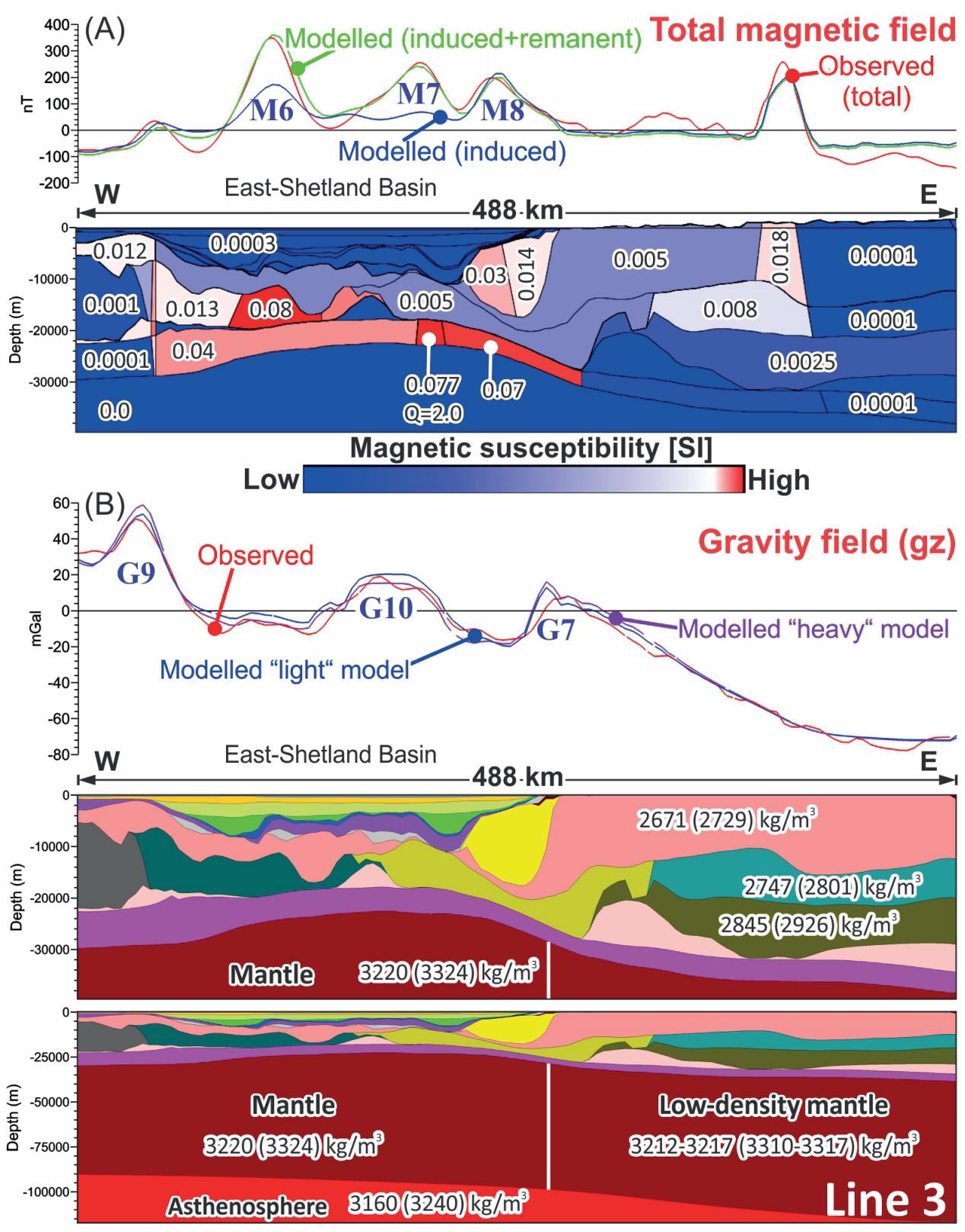

Figure 22. Selected vertical slice 3 through the 3D structural model in Fig. 19. (A) slice through the 3D magnetic model and (B) vertical slice through the 3D density model. The location of this slice is shown in Fig. 9. The 'light' model density is without brackets and the 'heavy' model density is in brackets.

nant magnetic minerals can be located deeper than the base of the crystalline crust beneath the East-Shetland Basin where the Moho is strongly uplifted (Fig. 22A). This slice crosses the prominent gravity low, bounded by the gravity highs G7 and G10, over the northernmost continuation of the Horda Platform (Fig. 9). According to the results of the 3D density modelling (Fig. 22B), this regional-scale gravity low is partially related to the presence of the low-density upper-crustal layer (the yellow body in Fig. 22B) which can be correlated lithologically with the highly compacted, pre-Permian, sedimentary or metasedimentary rocks and/or relatively light granitic rocks. Line 3 also crosses the East Shetland Basin and the northern part of the Viking Graben, and shows a wide Moho uplift beneath these basins. The prominent gravity high G9 is mostly associated with the uplift of the crystalline basement at the western shoulder of the EastShetland Basin.

It is important to mention that the lower and middle crystalline crust beneath the mainland along vertical slices 2 and 3 is characterised by a subhorizontal layering (Figs. $21 \& 22$ ) that is consistent with the result of the deep seismic refraction experiment 'Magnus-Rex' (Stratford et al., 2009). 


\section{Discussion}

At the outset, we would like to mention that, in the case of our 3D density modelling, it has been shown that at least two models with different densities of the crustal crystalline layers and the mantle can provide similar fits between the modelled and the observed gravities (cf., Figs. 8A \& 10A, C; Figs. 20-22). Therefore, there are uncertainties in the used densities and the magnitude of these uncertainties is partially represented by two end-member models with lower and higher densities, showing a preferred range of densities for the crystalline rocks. In the case of the $3 \mathrm{D}$ magnetic modelling, the main dilemma is not related to different susceptibilities responsible for similar modelled magnetic fields as was shown for the $3 \mathrm{D}$ density modelling. However, a remanent component of the magnetisation can locally be present, but hidden, if the paleomagnetic field has a declination and an inclination similar to those of the present day. Therefore, the induced magnetisation can be locally overestimated in terms of the increased magnetic susceptibilities in the case of the rocks with a relatively high density. In contrast, the influence of the remanent magnetisation can be generally neglected in the case of rocks with normal or low densities, because these rocks are usually represented by granites or gneisses which typically do not have a high remanent magnetisation based on measurements on rock samples.

Additional uncertainty can be associated with the magnetic properties of the upper mantle material. The magnetic susceptibility of the mantle material has been set to $0 \mathrm{SI}$, assuming that paramagnetic minerals are predominant in the upper mantle. Most of the paramagnetic minerals are characterised by low values of magnetic susceptibility on average (e.g., Clark, 1997). The dominance of paramagnetic minerals within the deep part of the study area is directly related to the Curie temperature or Curie Point when pressure is also considered. The reason is that 'ferromagnetic' (mostly ferrimagnetic and antiferromagnetic) minerals lose their magnetic properties at temperatures higher than the Curie Point. In this case, a reasonable way would be to define the Curie Point isotherm and set a boundary at depth for this isotherm where a marked change in magnetic properties of rocks occurs with relatively high-magnetic properties above the depth to the Curie Point isotherm due to a presence of 'ferromagnetic' minerals and very low magnetic properties below the depth to the isotherm. However, the Curie Point varies in a wide range for different minerals depending on their chemical composition (e.g., Clark, 1997; Pasquale, 2011) and, therefore, more detailed information on the composition of lower-crustal and uppermantle rocks is required for a reliable determination of the Curie Point isotherm. According to the 3D thermal modelling (Maystrenko, 2016), some of the uppermost mantle rocks are possibly located above the Curie isotherm for magnetite within the areas where the Moho is uplifted (Figs. 20A, 21A \& 22A). On the other hand, the modelled depth to the $580^{\circ} \mathrm{C}$ isotherm is located close to the Moho beneath a large part of the study area and can definitely vary, depending on the used thermal properties of the rocks. The latter does not allow us to define accurately the magnetic part of the mantle. To solve this dilemma, an assumption has been made that 'ferromagnetic' minerals are still present in the lower crust whereas they are almost absent in the upper mantle, assuming that the upper-mantle rocks are very low-magnetic ones and do not have a significant remanent magnetisation. Moreover, the long-wavelength component is typically not particularly accurate in aeromagnetic surveys due to the way the data are processed (e.g., Brönner et al., 2017), implying that a simplification for a crustal model is justified.

Uncertainties in the geometry is a common problem of both density and magnetic modelling. This is especially related to the shape of the Upper Permian (Zechstein) salt and top of the crystalline crust in the upper part of the model. The Moho discontinuity and the base of the lithosphere are the major boundaries at a deeper level. Depth to the Moho is constrained by deep seismic data (Fig. 3C) and the existing data gaps have been filled during the $3 \mathrm{D}$ density modelling, implying that the Moho is locally uncertain due to the non-uniqueness of the method. However, the largest uncertainties occur at the base of the Upper Permian (Zechstein) salt layer within the deeper parts of the Central Graben and the Norwegian-Danish Basin. The shape of the salt base is poorly imaged by seismic data beneath the salt structures and, therefore, the base of the Permian salt remains uncertain locally. Consequently, the top to the crystalline basement, is not reliably located beneath the thick salt layer in the Central Garaben and the Norwegian-Danish Basin, as well as the top basement is still not well defined within the deepest parts of the Viking Graben and the East-Shetland Basin. Therefore, the above-mentioned uncertainties of the input seismicbased data additionally complicate the modelling procedure.

In the case of the $3 \mathrm{D}$ density modelling, the problem is that the deep sedimentary rocks are theoretically highly compacted and, therefore, there is no a strong density contrast between the crystalline and sedimentary rocks, thus increasing the input data-related uncertainties of the depth to the top of the crystalline basement in deeper areas. Furthermore, a deep position of the crystalline basement does not always allow us to determine the top of the crystalline rocks during the $3 \mathrm{D}$ magnetic modelling. In this cases, the accuracy of the final model is almost completely dependent on the quality of the input seismic data, which have been locally modified in cases where the gravity and magnetic data do support the input configuration. For example, the top of the crystalline basement is locally about $18 \mathrm{~km}$ deep 
beneath the Norwegian-Danish Basin according to the data from Lassen \& Thybo (2012). On the other hand, such a deep location of the top basement makes it difficult to model the observed magnetic anomalies in that area and, therefore, the top basement has been shifted to a 3-4 km shallower depth in order to fit the observed and modelled magnetic fields. Therefore, the precise depth to the top of the crystalline basement in that area remains uncertain locally. To remove this and other uncertainties, the seismic data interpretation can be combined with the detailed potential field modelling or vice versa to better resolve the complex deep structure beneath the salt structures and/or beneath the thick sedimentary cover. Thus, the obtained results of the 3D density and magnetic modelling remain within the limitations discussed above.

\section{Low-density upper-crustal layer of the Horda Platform}

In order to fit the modelled gravity with the observed one, a relatively low density of $2630 \mathrm{~kg} / \mathrm{m}^{3}$ (the 'heavy' model density is $2675 \mathrm{~kg} / \mathrm{m}^{3}$ ) has been assigned to the almost north-south-elongated block of the upper crystalline crust within the Horda Platform (Fig. 13A, B). From a first view, the used average density is extremely low to be representative for the crystalline rocks, being as low as for sedimentary rocks. On the other hand, the measured densities on rock samples from Norway show even lower values according to the NGU petrophysical database (Olesen et al., 1993, 2010). Moreover, this low-density upper-crustal block can be at least partially represented by sedimentary or metasedimentary rocks, the density of which can obviously be lower than the assigned one. Unfortunately, we cannot properly distinguish between the metasedimentary and crystalline rocks of the modelled block, suggesting that the greater part of it consists of crystalline rocks which can be lithologically represented by granite or granitic gneiss. The crystalline basement of the south-eastern flank of the Viking Graben is fractured and porous within the Utsira High (Riber et al., 2015, 2016), allowing us to suggest that crystalline rocks of the low-density crustal block within the northeastern flank of the Viking Graben can also be fractured. The latter suggestion is supported by the results of $2 \mathrm{D}$ modelling of coupled groundwater flow and heat transfer through the middle-upper-crustal rocks of SW Norway (Maystrenko et al., 2015a). Maystrenko et al. (2015a) have shown that groundwater flow affects the subsurface temperatures in SW Norway, indicating the presence of fractures within the crystalline rocks. In the light of the recent oil discovery on the southern Utsira High within the fractured and porous granitic rocks (e.g., Lie et al., 2016), the crystalline rocks of the Horda Platform can be considered as one of the next possible targets for a more detailed investigation of hydrocarbon potential within the uppermost crystalline crust.
A reduction in density can also be related to an increased heat-flow density (Pascal, 2015) which is observed over the centre of the low-density upper-crustal layer where a broad zone of thickening is modelled (Fig. 13A). The increased radiogenic heat production of the modelled granitic rocks can be partially responsible for the observed increased heat-flow density, similarly to the adjacent areas of the mainland where granites or granitic gneisses with increased contents of the radiogenic elements have been recognised (Slagstad et al., 2009; Maystrenko et al., 2015b; Pascal \& Rudlang, 2016). A possible thermal influence on the low rock densities beneath the Horda Platform is indirectly supported by velocity and density measurements of rock samples under simultaneously increasing pressure and temperature by Korchin (2015) who has shown that a zone with slightly decreased velocity/density can be present under upper-crustal conditions. The magnitude and depth ranges of this upper crustal velocity/density decrease are dependent on the geothermal gradient. A higher geothermal gradient corresponds to a higher degree of density decrease and vice versa (Korchin, 2015). Therefore, the possible presence of decreased densities in the upper-crustal zone can reduce an average density of the whole upper-crustal column.

An influence of a low-density lithospheric mantle can produce a mass deficit beneath the Horda Platform in addition to the above-described factors. However, the detailed configuration of this atypical mantle is unknown and, therefore, it is difficult to estimate a real input from the deep levels. In any case, the gravity effect from the deep levels has a rather long wavelength, whereas our modelled low-density body is rather small, implying a crustal origin.

\section{Age of the upper-middle crustal intrusion in the Norwegian-Danish Basin}

The most prominent magmatic Skagerrak intrusion is located near the southern coast of Norway (Fig. 12A). Over the northern part of the Norwegian-Danish Basin, the intrusion-related, rounded, negative magnetic anomaly is well expressed by very low values of the total magnetic intensity (Fig. 8B) and is bounded by a highly intensive positive anomaly in the northeast, implying a presence of remanent magnetisation in addition to the induced one. Furthermore, these interconnected magnetic anomalies coincide spatially with the well pronounced positive gravity anomaly (cf., Fig. 8A, B) and, therefore, can be attributed to the presence of a magmatic gravity-derived intrusion near the southern coast of Norway. Unfortunately, the complex magnetic pattern associated with the intrusion could not be reproduced in detail during the 3D magnetic modelling due to the limited resolution of our 3D model and large uncertainties in the parameters of the paleomagnetic field. In addition, this intrusion is surrounded by upper crustal magmatic rocks (Fig. 12B) which can also complicate the magnetic 
field in that area. Therefore, additional integrated gravity and magnetic modelling has had to be performed by use of high-resolution structural data in order to resolve this highly complicated magnetic pattern unambiguously.

Here, we have tested two possible ages for this intrusion by use of the remanent declination and inclination for the Permian paleomagnetic field taken from Torsvik et al. (1997), and for the Sveconorwegian one used by Olesen et al. (2004) and taken from McEnroe et al. (1996). If the Sveconorwegian parameters of the paleomagnetic field (declination $293^{\circ}$ and inclination $64^{\circ}$ ) are used, the intrusion has to be represented by two combined, southward-dipping, low-magnetic and high-magnetic bodies as according to the previous attempt with the help of 2.5D magnetic modelling by Olesen et al. (2004) who assumed that this intrusion is a part of the Sveconorwegian Rogaland Igneous Province. The Skagerrak Graben is interpreted as a dry rift with a small volume of magmatic rocks (Heeremans \& Faleide, 2004). The mafic rocks of the Rogaland Igneous Province do, in general, show up as negative magnetic anomalies, whereas the felsic rocks have positive anomalies. Olesen et al. (2004) therefore interpreted the neighbouring positive anomalies adjacent to the negative Skagerrak anomaly in terms of an extension of the E-W-trending Farsund charnockite and Lyngdal granite on the nearby mainland.

In contrast, if the Permian parameters of the paleomagnetic field (declination $206^{\circ}$ and inclination $33^{\circ}$ ) are used, only the simple sub-vertical upper-middle crustal body is required to reproduce the observed magnetic field. A Permian age for this intrusion has also been suggested by Åm (1973) based on 2D magnetic modelling. Åm (1973) has also suggested a Cenozoic age for a small nearby intrusion that is not obvious from our point of view.

Consequently, a simple magnetic, sub-vertical, cylindrical body of Permian age can explain the observed magnetic field. Therefore, we have chosen a Permian age for this intrusion rather than the Sveconorwegian one based on the good fit between the modelled and observed magnetic fields (cf., Figs. 8C \& 11A). However, a Sveconorwegian age cannot be ruled out since the body seems to be closely associated wth the Lyngdal and Farsund instrusions that are part of the Rogaland Igneous Province. Voluminous magmatic bodies with reverse magnetisations are not known from the Oslo Rift. According to drilling data (Smelror et al., 1997; Evans et al., 2003; Heeremans \& Faleide, 2004), Permian volcanic rocks have not been encountered by any boreholes in the Farsund and Skagerrak grabens in the Norwegian sector of the North Sea; nor has there been observed any Permian volcanic rocks along the coast immediately to the north of the offshore intrusion. All these facts about the missing Permian magmatic rocks in the surrounding area allow us to suggest that a Sveconorwegian magmatic intrusion is a viable alternative to the Permian model age suggested by Åm (1973).

\section{Upper-crustal magmatic rocks}

The origin of the upper-crustal magmatic rocks is for the most part related to the Sweconorwegian or Caledonian orogenic events.

The magmatic rocks located in SW Norway and adjacent parts of the North Sea have a Sveconorwegian postcollisional age (930-920 Ma) and form the Rogaland Igneous Province (also called the Rogaland anorthositic province) (Fig. 12B). These rocks have been well studied within SW Norway where they comprise mainly anorthosite, norite and mangerite (Olesen et al., 2004; Van der Auwera et al., 2011; Brown \& McEnroe, 2015). According to the results of the $3 \mathrm{D}$ magnetic modelling, rocks of the Rogaland Igneous Complex can extend beneath the sedimentary cover offshore where they are responsible for a broad zone with several negative magnetic anomalies (cf., Figs. 8B \& 12B). However, the exact thickness and the distribution of the Rogaland Igneous Complex are mostly uncertain within areas covered by thick sedimentary rocks in the northern North Sea. The offshore thickness of the Rogaland Igneous Complex is especially problematic because Q-values of 3 and 7 have been assigned to these rocks during the $3 \mathrm{D}$ magnetic modelling, showing that higher values of the Q-factor will lead to a smaller thickness and vice versa. Unfortunately, there are no data about the Königsberger ratio for these igneous rocks offshore; and, onshore, the possible range of the Q-factor is relatively large according to Brown \& McEnroe (2004). Therefore, a strong variability of the paleomagnetic field parameters within the Rogaland Igneous Province does not allow us to model a detailed configuration of the total observed magnetic field. On the other hand, the thickness of the Rogaland Igneous Complex offshore cannot be much greater than the modelled one due to the reason that significantly thickened magmatic rocks would be reflected by a broad positive gravity anomaly. However, this is not the case according to the observed gravity field over the region where the Rogaland Igneous Complex has been modelled within the North Sea (cf., Figs. 8A \& 12B).

The largest Caledonian, upper-crustal, magmatic rocks within the study area include the Karmøy Ophiolite Complex, rocks of the Bergen Arc and the Jotun Nappe Complex (Fig. 12B). Altogether these rocks were brought to the Earth's surface during the Caledonian Orogeny (mainly in Silurian-Early Devonian time), forming an orogenic wedge over the crystalline rocks of the Precambrian, Baltican crust (e.g., Roberts \& Gee, 1985; Gee et al., 2008). At the present day, the upper-crustal magmatic rocks represent part of the metamorphic allochthon of the Scandinavian Caledonides. In particular, the Karmøy Ophiolite Complex consists of the ophiolitic igneous rocks which represent the remnants of the former Iapetus Ocean crust and associated island arcs (Menuge et al., 1989; Pedersen \& Hertogen, 1990; Poppleton \& Piper, 1990). The results of our 3D magnetic modelling demonstrate that the magnetically anomalous Karmøy Ophiol- 
ite Complex on the island Karmøy, where these rocks are exposed at the surface, can be also traced into the surrounding offshore areas (Fig. 12C).

The Bergen Arc System is a prominent geological feature of the study area due to its concave shape (Fig. 12B). The Bergen Arc System consists of a sequence of Caledonian nappes and also includes an ophiolite complex together with anorthosite, amphibolite and diverse schists (Ragnhildstveit \& Helliksen, 1997). Development of partial eclogitisation within one of the nappes indicates that these particular rocks were located at great depth near the base of the continental crystalline crust during a Mid Ordovician phase of the Caledonian orogeny at c. $460 \mathrm{Ma}$ (Bingen et al., 2000), implying a high grade of metamorphism and, therefore, a relatively high-density for these rocks on average. The latter is clearly reflected in the results of the $3 \mathrm{D}$ density modelling which show that these rocks, more than $5 \mathrm{~km}$ thick in this particular nappe, are characterised by a high density of 2840 (2842) $\mathrm{kg} / \mathrm{m}^{3}$ in spite of their location at the Earth's surface.

The Jotun Nappe Complex consists mainly of Precambrian granulite-facies rocks (Piper \& Poppleton, 1990) and is characterised by a complex structure, representing a deep segment of the Sveconorwegian orogen which is presently exposed at the surface (Lundmark et al., 2007) and, therefore, has a relatively high density on average.

\section{Suture zone between Baltica, Avalonia and Laurentia}

The outcome of the 3D density modelling supports previous results (Lyngsie et al., 2006; Lyngsie \& Thybo, 2007; Fichler et al., 2011; Smit et al., 2016) showing that the crystalline crust of the study area is not only heterogeneous in a vertical direction but it can be also subdivided into several horizontal blocks. From the west to the east, the modelled middle crystalline crust consists of four crustal domains, two of which are represented by middle crust of Laurentia and Avalonia (layer 15) and middle crust of Baltica (layer 16) with similar densities of $2746-2761$ and $2747 \mathrm{~kg} / \mathrm{m}^{3}$ (for the 'heavy' model $2780-2813$ and $2801 \mathrm{~kg} / \mathrm{m}^{3}$ ), respectively (Table 3 ). There is no question about the presence of these two different crustal blocks which were already quite well known (e.g., Cocks et al., 1997; Pharaoh, 1999). Actually, the middle crust of the continent Laurentia and the microcontinent Avalonia has to be further divided into two different blocks due to the reason that Avalonia and Laurentia joined the continent of Baltica at different times. Initially, Avalonia accreted to Baltica during Ordovician-Silurian closure of the Thor Ocean-Tornquist Sea, and only after that Laurentia joined the combined continent of Baltica-Avalonia during closure of the Iapetus Ocean in the Late Silurian (e.g., Torsvik \& Rehnström, 2003; Cocks \& Torsvik, 2006; Smit et al., 2016). However, our model area covers only a small piece of Avalonia in the southwestern corner of the model where the crust of Laurentia is also partially present. For that reason, there is no proper way to differentiate between the crustal domains of Laurentia and Avalonia within so small an area in the southwestern corner of the model, and the piece of Avalonian crust has been included in one layer together with Laurentia. Furthermore, the upper crustal layers of Baltica and Laurentia-Avalonia have been assigned the upper-crustal density of $2671 \mathrm{~kg} / \mathrm{m}^{3}\left(2729 \mathrm{~kg} / \mathrm{m}^{3}\right.$ in the case of the 'heavy' model) and are therefore represented by only one regional upper crustal layer (layer 12) in the 3D model.

There is a key question, however, about the precise location of the boundary between Laurentia and Baltica which is still uncertain. According to Lyngsie et al. (2006) and Lyngsie \& Thybo (2007), the suture zone between Laurentia and Baltica is located beneath the Central and Viking grabens at the upper-middle-crustal level with a lateral extension of the Baltican lower crust beneath the Central Graben. This possible lateral extent of the lower crust of Baltica is partially reflected in the modelled lower crust of Baltica (layer 17; Fig. 16). However, a relatively small thickness of the modelled lower crust beneath the Central and Viking grabens (Fig. 16) does not really answer the above-mentioned question. Unfortunately, the high-density lower crustal layer (layer 19; Fig. 17C) cannot be differentiated due to the impossibility of distinguishing between the lower high-density crusts of Baltica, Laurentia and Avalonia, and a part of this layer beneath the Viking Graben may thus have at least a partial Baltican origin. On the other hand, the extension of Baltican lower crust beneath the southwestern flank of the Central Graben is not obvious according to Smit et al. (2016) who suggested that there were remnants of the Caledonian accretionary complex between Avalonia and Baltica based on the presence of the low P-wave velocity zone in the lower crust of the southwestern flank of the Central Graben. The latter is reflected in part by a thinning of the high-density lower-crustal layer beneath the southwestern flank of the Central Graben in the case of our model (Figs. 17C \& 20B).

Furthermore, Fichler et al. (2011) have suggested that the collision between the Laurentian and Baltican crustal domains occurred within a tectonically complex region, involving at least two island arc chains which were inferred by them to be present at the western boundary of Baltica during the final closure of the Iapetus Ocean in Late Silurian times. In accordance with Fichler et al. (2011), layer 14 with western central North Sea rocks can at least partially correspond to inherited island arc rocks, a suggestion that can be supported by the increased densities of $2784-2801 \mathrm{~kg} / \mathrm{m}^{3}$ (for the 'heavy' model 2829$2860 \mathrm{~kg} / \mathrm{m}^{3}$ ) of layer 14 compared to the rest of the middle-crustal layers (Table 3 ). 


\section{High-density lower-crustal layer and intracrustal high-density crust}

The modelled high-density lower-crustal layer is characterised by an almost constant thickness beneath the mainland (Fig. 17C). This feature and the deep position of the layer implies that these rocks have undergone intermediate- to high-grade metamorphism and their high density of $3055 \mathrm{~kg} / \mathrm{m}^{3}\left(3160 \mathrm{~kg} / \mathrm{m}^{3}\right.$ for the 'heavy' model) may, therefore, reflect these metamorphic conditions and processes. On the other hand, the origin of the high-density lower-crustal layer is not so straightforward offshore and can be related to several processes, depending on the location. For instance, the origin of the magnetic high M1 is most likely related to a marked thickening of the high-density lower-crustal layer (Fig. 20). In the vicinity of this thickened, high-density, lower-crustal body, the Late Carboniferous-Early Permian sill complex within the Palaeozoic sedimentary rocks, including the lower part of the Permian, has been recognised based on a detailed analysis of the $3 \mathrm{D}$ seismic data at the northern rim of the Ringkøbing-Fyn High (Clausen et al., 2016). In connection with these numerous sills, the thickened high-density lower crust can be considered as a magmatic feeder layer for the interpreted upper crustal sills and, therefore, could theoretically also hsve been formed during Late Carboniferous-Early Permian times. Actually, the configuration and location of this crustal body indicate some similarities with a well-known, massive, high-density, high-velocity body within the crust of central Denmark (Sandrin \& Thybo, 2008; Sandrin et al., 2009) where a strong positive gravity anomaly (the Silkeborg Gravity High) is observed. This massive intrusive body in central Denmark has been also interpreted to be possibly associated with the Late Carboniferous-Early Permian extensional/transtensional tectonics (Sandrin \& Thybo, 2008; Sandrin et al., 2009; Thybo \& Nielsen, 2012). In this case, the same Late Carboniferous-Early Permian age can also be suggested for most of the thickened high-density lower-crustal bodies within the southeastern part of the study area. There, within the Norwegian-Danish Basin, the high-density lower-crustal layer is significantly thickened (Fig. 17C, D). Moreover, the location of the modelled Permian intrusion in that area (Fig. 12A) together with the already mentioned Permian magmatic rocks within the northeastern part of the North Sea (Evans et al., 2003; Heeremans \& Faleide, 2004), support at least in part a Late CarboniferousEarly Permian origin for the anomalously thickened high-density lower crust beneath the Northern Permian Basin. However, a Sveconorwegian or even older age for the thickening of the high-density lower-crustal layer cannot be excluded in this part of the 3D model. The Sveconorwegian or older age is indirectly supported by a numerical dynamic model of the Late Palaeozoic and Mesozoic formation and evolution of the NorwegianDanish Basin (Frederiksen et al., 2001a). Frederiksen et al. (2001a) were able to model basin geometry, thicknesses of sedimentary rocks, stratigraphy, crustal thick- ness and heat flow without involving magmatic processes which would have led to an increase of density and thickness of the lower crust during the Late CarboniferousEarly Permian event. Consequently, the question about the origin and age of the high-density lower-crustal layer beneath the Norwegian-Danish Basin is still open.

Farther to the north, there is magnetically anomalous zone of thickening of the high-density lower-crustal layer beneath the western boundary fault of the Viking Graben (Fig. 17D). This zone can also be traced at the shallower levels with a less dense material, modelled by the highdensity intracrustal crust (Fig. 17B). The high-density intracrustal layer has actually been included into the $3 \mathrm{D}$ density model to fit the observed and the calculated gravity where the gravity effect of the (denser) highdensity lower-crustal layer was not sufficient. Taking into account the specific locations of the high-density crustal blocks with increased magnetic susceptibility (Fig. 17B, D), it can be inferred that these anomalous zones could have been formed during Mesozoic time when the major stages of subsidence occurred along this boundary fault of the Viking Graben and, therefore, the crystalline crust could have been locally modified. Alternatively, these anomalous zones could be much older, representing preexisting heterogeneities in the crystalline crust which controlled the localisation of large-scale brittle deformations during the formation of the above-mentioned sedimentary basins in the Mesozoic. Consequently, the role of the magnetically anomalous blocks of the high-density intracrustal layer beneath the triple junction of the Central and Viking grabens and the Moray Firth Basin (Fig. 17B) could also be important in localisation of the brittle deformations during the formation of these Mesozoic sedimentary basins within the northern North Sea.

Within the northern part of the model (Fig. 17D), three intensive positive magnetic anomalies (M6, M7 and M8) are at least partially associated with the high-density lower-crustal layer (cf., Figs. 8A \& 17D). The magnetically anomalous lower crust could have originated from the former upper-mantle peridotites which were serpentinised and, therefore, represent the high-density lower crust at the present day (Fig. 22). This suggestion is based on the geologically logical explanation by Fichler et al. (2011) for the origin of the magnetic anomaly M6. However, in the case of our study, the major magnetic source for the anomaly M6 is located within the middle crust, whereas the high-density lower crust is only the secondary magnetic source. This has been done on account of the rather high amplitude of the magnetic anomaly M6 with a relatively steep vertical gradient that would require a relatively shallow source (Fig. 22). In any case, the lower crust also has to be magnetic in that area according to the results of the $3 \mathrm{D}$ magnetic modelling. On the other hand, the origin of the magnetic anomaly M7 is completely related to the high-density lowercrustal layer because the upper-middle crust is very thin immediately towards the north of Line 3 and, therefore, 
cannot be considered to be a major magnetic source for anomaly M7. The magnetic anomaly M8 has a combined origin from the upper and lower crustal layers with the main source in the high-density lower crust (Fig. 22A). As has been described above, the high-density lower crust is characterised by an increased magnetic susceptibility along Line 3 and surrounding areas (Figs. 17D \& 22A). In accordance with Fichler et al. (2011), who proposed that the lower crustal block with high magnetic susceptibility, responsible for the origin of anomaly M6, is represented by inherited serpentinites, we propose that a similar mechanism can be applied to the origin of anomalies M7 and M8. Therefore, the modelled wide zone of the anomalous lower crust can be partially represented by the serpentinised peridotites (Fig. 17D). These lower-crustal serpentinites could have been generated by the dehydration of the subduction slab as it descended into the uppermost mantle rocks during the Caledonian Orogeny (Fichler et al., 2011). It has to be mentioned for completeness that the origin of the observed anomalies M6, M7 and M8 can also be attributed to the upper-mantle rocks because, based on the $3 \mathrm{D}$ thermal modelling (Maystrenko, 2016), the Curie isotherm for the dominant magnetic minerals can be theoretically located deeper than the base of the crystalline crust beneath the EastShetland Basin where the Moho is strongly uplifted (Figs. $18 \mathrm{~A} \& 22 \mathrm{~A})$.

\section{Low-density mantle beneath SW Norway}

According to the results of the $3 \mathrm{D}$ density modelling, the $3 \mathrm{D}$ model requires low-density lithospheric mantle beneath the Norwegian mainland and adjacent areas (Fig. 18). In the case of the same density for the lithospheric mantle for the whole model area, a positive gravity anomaly would be modelled over the continent, indicating a mass excess there. Recently, a similar or even more pronounced low-density mantle has been modelled based on the 3D density modelling beneath the large part of the Lofoten-Vesterålen segment of the Mid-Norwegian continental margin (Maystrenko et al., 2017). However, as in the case of Maystrenko et al. (2017), there are not enough data to properly identify the specific shape or distribution of density with a depth of this atypically low-density mantle based solely on 3D density modelling. In the case of this study, the whole column of the lithospheric mantle beneath the continent has been assigned a lower density of $3206-3208 \mathrm{~kg} / \mathrm{m}^{3}$ (3301-3316 $\mathrm{kg} / \mathrm{m}^{3}$ for the 'heavy' model) in comparison with the rest of the lithospheric mantle with a density of $3220 \mathrm{~kg} / \mathrm{m}^{3}$ $\left(3324 \mathrm{~kg} / \mathrm{m}^{3}\right.$ for the 'heavy' model). From the theoretical point of view, however, the existing mass deficit in the lithospheric mantle can also be related to either a small mantle body in the uppermost part of the mantle or a large one in the deeper mantle.

An anomalous upper mantle beneath SW Scandinavia was already suggestedby Bannister et al. (1991) who published their results on seismic tomography, showing a clearly distinguished area with low velocity beneath SW Norway and adjacent areas. Later on, according to teleseismic P-wave and/or S-wave tomography and surface wave analysis, the shape of reduced upper-mantle velocities beneath SW Norway has been reported in more detail (Maupin, 2011; Köhler et al., 2015; Medhus et al., 2012; Maupin et al., 2013; Wawerzinek et al., 2013). This reduction in seismic velocities is also supported by the recent results of Hejrani et al. $(2015,2017)$ and Kolstrup et al. (2015), who have shown, based on P- and S-wave velocities tomography, that there is a prominent lowvelocity zone within the upper mantle of SW Norway. Moreover, based on isostatic modelling, a low-density mantle beneath the southern Scandes has already been proposed by Olesen et al. (2002) and Ebbing et al. (2012) in order to explain the relatively high topography of the Scandes mountain chain in SW Norway. However, in spite of a more than 25-year period of intensive studies, the nature of the low-velocity zone beneath SW Norway still remains unclear because there is no simple explanation for the reduction of upper-mantle velocities/densities in that area (e.g., Medhus et al., 2012; Gradmann et al., 2013; Maupin et al., 2013; Kolstrup et al., 2015). It is obvious that the reduction in velocities can have a thermal and/ or compositional origin but an input of each component cannot be properly estimated. Furthermore, according to thermal modelling by Pascal and Olesen (2009), the mass deficit beneath SW Norway is not likely to have originated from a deep-seated thermal anomaly alone. In a more recent publication, based on thermal modelling, geological and chronological data, Slagstad et al. (in press) have proposed that the atypical upper mantle beneath SW Norway still reflect the influence of the Sveconorwegian orogeny. Nevertheless, based on potential field modelling, we are not able to recognise the detailed structure of the low-velocity/low-density upper mantle beneath the continent and, therefore, we leave the question about the nature of this upper mantle anomaly open.

\section{Conclusions}

As a general summary, it can be stated that an integration of all available structural data in combination with the $3 \mathrm{D}$ gravity analysis allowed us to evaluate a firstorder configuration of the crystalline crust within the northern part of the North Sea and adjacent areas of the Norwegian mainland. Moreover, different magnetic anomalies have different origins, depending on the structural features of the study area and the magnetic properties (lithology) of crystalline rocks. Based on the results of the 3D magnetic modelling, the 3D density-structural model has been expanded by including into the model's layers a magnetically anomalous part with crustal blocks which are characterised by increased magnetic susceptibility and, therefore, these blocks differ lithologically 
from the rest of the original density-derived layers. In particular, the most important results of the combined 3D density and magnetic modelling are the following: The obtained configuration of the top of the crystalline basement is characterised by a complex structure offshore where it is almost $14 \mathrm{~km}$ deep within the northeastern part of the Norwegian-Danish Basin (the Skagerrak Graben). All major sedimentary basins, such as the Central and Viking grabens, and the East-Shetland and Norwegian-Danish basins, are clearly reflected by a marked increase of depths to the crystalline basement within the rest of the northern North Sea.

The modelled Moho is deeply situated beneath the continent at $32-40 \mathrm{~km}$ depth but is uplifted to $20 \mathrm{~km}$ beneath the axial parts of the Central and Viking grabens. The lithosphere-asthenosphere boundary shows long-wavelength variations in the range of $\pm 10-15 \mathrm{~km}$ on average at around depth of $100 \mathrm{~km}$.

A low-density upper-crustal block is required beneath the Horda Platform in order to remove mass excess. These modelled low-density rocks indicate the possible presence of metasedimentary and/or fractured granitic rocks beneath this platform.

A possible Permian middle-upper crustal magmatic intrusion has been modelled within the northern part of the Norwegian-Danish Basin. The regional magnetic pattern and known geology from the mainland, as well as offshore reflection seismics and borehole data, indicate, however, that a Sveconorwegian origin is a more viable alternative.

Separate middle-crustal blocks with different densities have been modelled within the central part of the North Sea beneath the Central and Viking grabens, supporting previous results about the possible presence of island arc chains between Laurentia and Baltica during the Caledonian time period.

A low-density area within the lithospheric mantle has been modelled beneath the continent and adjacent offshore areas, reflecting the presence of an upper-mantle low-velocity zone there. The nature of this low-density mantle material is not clear but it can be related to increased temperature and/or compositional changes within the lithospheric and deeper mantle.

Acknowledgements. We are thankful to Aker BP, BayernGas, BKK, ConocoPhillips, Dea, DONG energy, Engie, Eni, E.ON, Lundin, Maersk, NGU, Noreco, NPD, Repsol, Statoil, Total, VNG and Wintershall for supporting our research in the framework of the 'Crustal OnshoreOffshore Project (COOP), Phase 1'. We thank Torleif Lauritsen for his helpful assistance with the NGU petrophysical electronic database. The authors are also grateful to Niels Balling and Paul Williamson for their very constructive and encouraging reviews, which helped to improve the manuscript significantly.

\section{References}

Abramovitz, T. \& Thybo, H. 1999: Pre-Zechstein structures around the MONA LISA deep seismic lines in the southern Horn Graben area. Bulletin of the Geological Society of Denmark 45, 99-116.

Abramovitz, T. \& Thybo, H. 2000: Seismic images of Caledonian, lithosphere-scale collision structures in the southeastern North Sea along MONA LISA profile 2. Tectonophysics 317, 27-54.

https://doi.org/10.1016/S0040-1951(99)00266-8.

Andersen, O.B., Knudsen, P. \& Berry, P.A.M. 2010: The DNSC08GRA global marine gravity field from double retracked satellite altimetry. Journal of Geodesy 84, 191-199.

https://doi.org/10.1007/s00190-009-0355-9.

Artemieva, I.M., Thybo, H. \& Kaban, M.K. 2006: Deep Europe today: Geophysical synthesis of the upper mantle structure and lithospheric processes over 3.5 Ga. In Gee D.G. \& Stephenson, R.A. (eds.): European Lithosphere Dynamics, Geological Society of London, The Geological Society Publishing House, Bath, pp. 11-41. https://doi.org/10.1144/GSL.MEM.2006.032.01.02.

Artemieva, I.M. \& Thybo, H. 2013: EUNAseis: A seismic model for Moho and crustal structure in Europe, Greenland, and the North Atlantic region. Tectonophysics 609, 97-153. https://doi.org/10.1016/j.tecto.2013.08.004.

Badley, M.E., Price, J.D., Dahl, C.R. \& Agdestein, T. 1988: The structural evolution of the northern Viking Graben and its bearing upon extensional modes of basin formation. Journal of the Geological Society 145, 455-472. https://doi.org/10.1144/gsjgs.145.3.0455.

Balling, N. 2000: Deep seismic reflection evidence for ancient subduction and collision zones within the continental lithosphere of northwestern Europe. Tectonophysics 329, 269-300.

https://doi.org/10.1016/S0040-1951(00)00199-2.

Bannister, S.C., Ruud, B.O. \& Husebye, E.S. 1991: Tomographic estimates of sub-Moho seismic velocities in Fennoscandia and structural implications. Tectonophysics 189, 37-53. https://doi.org/10.1016/0040-1951(91)90486-C.

Barton, P.J. 1986: The relationship between seismic velocity and density in the continental crust - a useful constraint? Geophysical Journal of the Royal Astronomical Society 87, 195-208.

https://doi.org/10.1111/j.1365-246X.1986.tb04553.x.

Barton, P. \& Wood, R. 1984: Tectonic evolution of the North Sea basin: crustal stretching and subsidence. Geophysical Journal of the Royal Astronomical Society 79, 987-1022. https://doi.org/10.1111/j.1365-246X.1984.tb02880.x.

Bassett, M.G. 2003: Sub-Devonian geology. In Evans, D., Graham, C., Armour, A. \& Bathurst, P. (eds.): The Millennium Atlas: Petroleum Geology of the Central and Northern North Sea, The Geological Society of London, London, pp. 50-59.

Bell, R.E., Jackson, C.A.L., Whipp, P.S. \& Clements, B. 2014: Strain migration during multiphase extension: observations from the northern North Sea. Tectonics 33, 1936-1963. https://doi.org/10.1002/2014TC003551.

Berthelsen, A. 1992: From Precambrian to Variscan Europe. In Blundell, D.J., Freeman, R., Mueller, S. (eds.): A Continent Revealed - The European Geotraverse, Cambridge University Press, pp. 153-164.

Bingen, B., Davis, W.J. \& Austrheim. H, 2000: Zircon U-Pb geochronology in the Bergen arc eclogites and their Proterozoic protoliths, and implications for the pre-Scandian evolution of the Caledonides in western Norway. Geological Society of America Bulletin 113, 640-649. https://doi.org/10.1130/0016-7606(2001)113<0640:ZUPGIT>2.0.CO;2. 
Bingen, B., Nordgulen, Ø. \& Viola, G. 2008: A four-phase model for the Sveconorwegian orogeny, SW Scandinavia. Norwegian Journal of Geology 88, 43-72.

Bolle, O., Diot H. \& Trindade, R.I.F. 2003: Magnetic fabrics in the Holum granite (Vest-Agder, southernmost Norway): implications for the late evolution of the Sveconorwegian (Grenvillian) orogen of SW Scandinavia. Precambrian Research 121,221-249.

https://doi.org/10.1016/S0301-9268(03)00013-5.

Britze, P. \& Japsen, P. 1991: The Danish Basin. 'Top Zechstein' and the Triassic (two-way traveltime and depth, thickness and interval velocity). Geological map of Denmark, scale 1:400,000, Geological Survey of Denmark.

Brönner, M., Baykiev, E. \& Ebbing, J., 2017: Workflow with pitfalls to derive a regional airborne magnetic compilation. EGU General Assembly 2017, Geophysical Research Abstracts 19, EGU2017-6210.

Brown, L.L. \& McEnroe, S.A. 2004: Palaeomagnetism of the EgersundOgna anorthosite, Rogaland, Norway, and the position of Fennoscandia in the Late Proterozoic. Geophysical Journal International 158, 479-488. https://doi.org/10.1111/j.1365-246X.2004.02349.x.

Brown, L.L. \& McEnroe, S.A. 2015: 916 Ma Pole for southwestern Baltica: palaeomagnetism of the Bjerkreim-Sokndal layered intrusion, Rogaland Igneous Complex, southern Norway. Geophysical Journal International 203, 567-587. https://doi.org/10.1093/gji/ggv299.

Calcagnile, G. 1982: The lithosphere-asthenosphere system in Fennoscandia. Tectonophysics 90, 19-35.

https://doi.org/10.1016/0040-1951(82)90251-7.

Calcagnile, G., Del Gaudio, V. \& Pierri, P. 1997: Lithosphere-asthenosphere system in shield areas of North America and Europe. Annals of Geophysics 40, 1043-1056.

Christensen, N.I. \& Mooney, W.D. 1995: Seismic velocity structure and the composition of the continental crust: A global view. Journal of Geophysical Research 100, 9761-9788. https://doi.org/10.1029/95JB00259.

Christiansson, P., Faleide, J.E. \& Berge, A.M. 2000: Crustal structure in the northern North Sea - An integrated geophysical study. Geological Society London, Special Publication 167, 15-40. https://doi.org/10.1144/GSL.SP.2000.167.01.02.

Christie, P.A.F. 1982: Interpretation of refraction experiments in the North Sea, Philosophical Transactions of the Royal Society A 305, 101-112. https://doi.org/10.1098/rsta.1982.0028.

Clark, D.A. 1997: Magnetic petrophysics and magnetic petrology: aids to geological interpretation of magnetic surveys. AGSO Journal of Australian Geology and Geophysics 17, 83-103.

Clausen, O.R., Gregersen, U., Michelsen, O. \& Sørensen, J.C. 1999: Factors controlling the Cenozoic sequence development in the eastern parts of the North Sea. Journal of the Geological Society 156, 809816. https://doi.org/10.1144/gsigs.156.4.0809.

Clausen, O.R., Andresen, K.J. \& Rasmussen, J.A. 2016: A Late Paleozoic sill complex and related paleo-topography in the eastern North Sea analyzed using 3D seismic data. Tectonophysics 674, 76-88.

https://doi.org/10.1016/j.tecto.2016.02.010.

Cocks, L.R.M. \& Torsvik, T.H. 2006: European geography in a global context from the Vendian to the end of the Palaeozoic. In Gee, D.G., Stephenson, R.A. (eds.): European Lithosphere Dynamics, Geological Society of London, Memoirs 32, pp. 83-95.

https://doi.org/10.1144/GSL.MEM.2006.032.01.05.

Cocks, L.R.M., McKerrow, W.S. \& Van Staal, C.R. 1997: The margin of Avalonia. Geological Magazine 134, 627-636.

https://doi.org/10.1017/S0016756897007425.
Cotte, N., Pedersen, H.A. \& Tor Working Group 2002: Sharp contrast in lithospheric structure across the Sorgenfrei-Tornquist Zone as inferred by Rayleigh wave analysis of TOR1 project data. Tectonophysics 360, 75-88.

Dadlez, R. 2000: Pomeranian Caledonides (NWPoland), fifty years of controversies: a review and a new concept. Geological Quarterly 44, 221-236.

Davis, M.W., White, N.J., Priestley, K.F., Baptie, B.J. \& Tilmann, F.J. 2012: Crustal structure of the British Isles and its epeirogenic consequences. Geophysical Journal International 190, 705-725. https://doi.org/10.1111/j.1365-246X.2012.05485.x.

Ebbing, J. \& Olesen, O. 2010: New compilation of to basement and basement thickness for the Norwegian continental shelf reveals the segmentation of the passive margin system. In Vining, B.A. \& Pickering, S.C. (eds.): Petroleum Geology: From mature basins to new frontiers, Proceedings of the 7th Petroleum Geology Conference, Petroleum Geology Conference Series 7, Geological Society of London, pp. 885-897. https://doi.org/10.1144/0070885.

Ebbing, J. \& Osmundsen, P.T. 2013: 2D profiles. In Olesen, O., Bronner, M., Ebbing, J., Elvebakk, H., Gellein, J., Koziel, J., Lauritsen, T., Lutro, O., Maystrenko, Y., Müller, C., Nasuti, A., Osmundsen, P.T., Slagstad, T. \& Storrø G. (eds.): COOP Phase I - Crustal Onshore-Offshore Project, NGU Report 2013.002, pp. 97-111.

Ebbing, J., England, R., Korja, T., Lauritsen, T., Olesen, O., Stratford, W. \& Weidle, C. 2012: Structure of the Scandes lithosphere from surface to depth. Tectonophysics 536, 1-24. https://doi.org/10.1016/j. tecto.2012.02.016.

Erickson, D. 2004: Crustal structure beneath an exposed eclogite terrain, southwestern Norway: inferred from wide-angle seismic techniques. MSc Thesis, University of Wyoming, $60 \mathrm{pp}$.

Erratt, D., Thomas, G.M., Wall, G.R.T. 1999: The evolution of the Central North Sea Rift. In Fleet, A.J., Boldy, S.A.R. (eds.): Petroleum Geology of Northwest Europe. Proceedings of the 5th Conference, The Geological Society of London, pp. 63-82. https://doi.org/10.1144/0050063.

Evans, D., Graham, C., Armour, A., Bathurst, P. 2003. The Millennium Atlas: Petroleum Geology of the Central and Northern North Sea. The Geological Society of London, London, $389 \mathrm{pp}$.

Færseth, R.B. 1996: Interaction of permo-triassic and jurassic extensional faultblocks during the development of the northern North Sea. Journal of the Geological Society 153, 931-944. https://doi.org/10.1144/gsigs.153.6.0931.

Fichler, C., Odinsen, T., Rueslåtten, H., Olesen, O., Vindstad, J.E. \& Wienecke, S. 2011: Crustal inhomogeneities in the Northern North Sea from potential field modelling: Inherited structure and serpentinites? Tectonophysics 510, 172-185. https://doi.org/10.1016/j.tecto.2011.06.026.

Fossen, H., Khani, H.F., Faleide, J.I., Ksienzyk, A.K. \& Dunlap, W.J. 2016: Post-Caledonian extension in the West Norway - northern North Sea region: the role of structural inheritance. Geological Society of London, Special Publications 439. https://doi.org/10.1144/SP439.6.

Fraser, S.I., Robinson, A.M., Johnson, H.D., Underhill, J.R., Kadolsky, D.G.A., Connell, R., Johannesson, P. \& Ravnes, R. 2003: Upper Jurassic. In Evans, D., Graham, C., Armour, A., Bathurst, P. (eds.): The Millennium Atlas: Petroleum Geology of the Central and Northern North Sea, Geological Society of London, pp. 157-189.

Frederiksen, S., Nielsen, S.B. \& Balling, N. 2001a: A numerical dynamic model for the Norwegian-Danish Basin. Tectonophysics 343, 165183. https://doi.org/10.1016/S0040-1951(01)00223-2. 
Frederiksen, S., Nielsen, S.B. \& Balling, N. 2001b: Post Permian evolution of the Central North Sea: a numerical model. Tectonophysics 343, 185-203. https://doi.org/10.1016/S0040-1951(01)00224-4.

Gee, D.G., Fossen, H., Henriksen, N. \& Higgins, A.K. 2008: From the early Paleozoic platforms of Baltica and Laurentia to the Caledonide orogen of Scandinavia and Greenland. Episodes 31, 44-51.

Geissler, W.H., Sodoudi, F. \& Kind, R. 2010: Thickness of the central and eastern European lithosphere as seen by $\mathrm{S}$ receiver functions. Geophysical Journal International 181, 604-634.

Geological Survey of Denmark and Greenland 2015: Well data summary sheets. http://www.geus.dk/departments/geol-info-data-centre/well-data-summary-sheets/well-index.htm (November 2015).

Geological Survey of Denmark and Greenland 2016: Well data summary sheets.

http://www.geus.dk/departments/geol-info-data-centre/well-datasummary-sheets/well-index.htm (November 2016).

GEUS (Geological Survey of Denmark and Greenland) 2011: Well data summary sheets.

http://www.geus.dk/departments/geol-info-data-centre/well-datasummary-sheets/well-index.htm (November 2011).

Götze, H.J. 1978: Ein numerisches Verfahren zur Berechnung der gravimetrischen Feldgroßen drei-dimensionaler Modellkörper. Archives for Meteorology, Geophysics and Bioclimatology, Series A, 195-215.

Götze, H.J. \& Lahmeyer, B. 1988: Application of three-dimensional interactive modelling in gravity and magnetics. Geophysics 53, 1096-1108. https://doi.org/10.1190/1.1442546.

Götze H.J. \& Schmidt, S. 2010: IGMAS+: A new 3D gravity, FTG and magnetic modelling software tool, ASEG-PESA Airborne Gravity Workshop, Expanded Abstracts, 91-96, ISBN 978-1-921781-17-9.

Grad, M., Tiira, T. \& ESC Working Group 2009: The Moho depth map of the European Plate. Geophyical Journal International 176, 279292.

Gradmann, S., Ebbing, J. \& Fullea, J. 2013. Integrated geophysical modelling of a lateral transition zone in the lithospheric mantle under Norway and Sweden. Geophysical Journal International 194, 13581373. https://doi.org/10.1093/gji/ggt213.

Graversen, O. 2002: A structural transect between the central North Sea Dome and the South Swedish Dome: Middle Jurassic-Quaternary uplift/subsidence reversal and exhumation across the eastern North Sea Basin. In Doré, A.G., Cartwright, J., Stoker, M.S., Turner, J.P., White, N. (eds.): Exhumation of the North Atlantic Margin: Timing, Mechanisms and Implications for Petroleum Exploration, Geological Society of London, Special Publications 196, pp. 67-83. https://doi.org/10.1144/GSL.SP.2002.196.01.05.

Gregersen, S. \& Voss, P. 2002: Summary of project TOR: delineation of a stepwise, sharp, deep lithosphere transition across GermanyDenmark-Sweden. Tectonophysics 360, 61-73.

https://doi.org/10.1016/S0040-1951(02)00347-5.

Gregersen, S., Glendrup, M., Larsen, T.B., Voss, P. \& Rasmussen, H.P. 2005: Seismology: neotectonics and structure of the Baltic Shield. Geological Survey of Denmark and Greenland Bulletin 7, 25-28.

Guterch, A. \& Grad, M. 2006: Lithospheric structure of the TESZ in Poland based on modern seismic experiments. Geological Quarterly 50, 23-32.

Hansen, D.L. \& Nielsen, S.B. 2003: Why rifts invert in compression. Tectonophysics 373, 5-24.

https://doi.org/10.1016/S0040-1951(03)00280-4.
Heeremans, M. \& Faleide, J.I. 2004: Late Carboniferous-Permian tectonics and magmatic activity in the Skagerrak, Kattegat and the North Sea. In Wilson, M., Neumann, E.R., Davies, G.R., Timmerman, M.J., Heeremans, M., Larsen, B.T. (eds.): Permo-Carboniferous Magmatism and Rifting in Europe, Geological Society of London, Special Publications 223, pp. 157-176.

https://doi.org/10.1144/GSL.SP.2004.223.01.07.

Hejrani, B., Balling, N., Jacobsen \& Tilmann, F. 2015: Upper-mantle Pand S- wave velocities across the Northern Tornquist Zone from traveltime tomography. Geophysical Journal International 203, 437-458. https://doi.org/10.1093/gji/ggv291.

Hejrani, B., Balling, N., Jacobsen \& England, R. 2017: Upper-mantle velocities below the Scandinavian Mountains from P- and S-wave traveltime tomography. Geophysical Journal International 208, 177192. https://doi.org/10.1093/gji/ggw370.

Hovland, M. 1987: Tertiary intrusives in western Skagerrak? Marine Geology 78, 175-182. https://doi.org/10.1016/0025-3227(87)90077-6

IOC, IHO \& BODC 2003: Centenary Edition of the GEBCO Digital Atlas, published on CD-ROM on behalf of the Intergovernmental Oceanographic Commission and the International Hydrographic Organization as part of the General Bathymetric Chart of the Oceans, British Oceanographic Data Centre, Liverpool, UK.

Iwasaki, T., Sellevoll, M.A., Kanazawa, T., Veggeland, T. \& Shimamura, H. 1994: Seismic refraction crustal study along the Sognefjord, south-west Norway, employing ocean-bottom seismometers, Geophysical Journal International 119, 791-808. https://doi.org/10.1111/j.1365-246X.1994.tb04018.x.

Japsen, P. 1993: Influence of lithology and Neogene uplift on seismic velocities in Denmark; implications for depth conversion of maps. American Association of Petroleum Geologists Bulletin 77, 194-211.

Japsen, P. 1998: Regional velocity-depth anomalies, North Sea Chalk: a record of overpressure and Neogene uplift and erosion. American Association of Petroleum Geologists Bulletin 82, 2031-2074.

Japsen, P. 1999: Overpressured Cenozoic shale mapped from velocity anomalies relative to a baseline for marine shale, North Sea. Petroleum Geoscience 5, 321-336. https://doi.org/10.1144/petgeo.5.4.321.

Japsen, P. \& Langtofte, C. 1991a: The Danish Basin. 'Base Chalk' and the Chalk Group (Two-Way Traveltime and Depth, Thickness and Interval Velocity), Geological Map of Denmark, scale 1:400,000, Geological Survey of Denmark, Copenhagen, Map Series 29.

Japsen, P. \& Langtofte, C. 1991b: The Danish Basin. 'Top Trias' and the Jurassic-Lower Cretaceous (two-way traveltime and depth, thickness and interval velocity). Geological map of Denmark, scale 1:400,000, Geological Survey of Denmark, Map Series 30.

Jordt, H., Thyberg, B.I. \& Nøttvedt, A. 2000: Cenozoic evolution of the central and northern North Sea with focus on differential vertical movements of the basin floor and surrounding clastic source areas. In Nottvedt, A. (ed.): Dynamics of the Norwegian Margin, Geological Society of London, Special Publications 167, pp. 219-243. https://doi.org/10.1144/GSL.SP.2000.167.01.09.

Kaban, M.K., Tesauro, M. \& Cloetingh, S. 2010: An integrated gravity model for Europe's crust and upper mantle. Earth and Planetary Science Letters 296, 195-209. https://doi.org/10.1016/j.epsl.2010.04.041.

Kelly, A., England, R.W. \& Maguire, P.K.H. 2007: A crustal seismic velocity model for the UK, Ireland and surrounding seas. Geophysical Journal International 171, 1172-1184. https://doi.org/10.1111/j.1365-246X.2007.03569.x. 
Klemperer, S.L. \& White, N. 1989: Coaxial stretching or lithospheric simple shear in the North Sea? Evidence from deep seismic profiling and subsidence. In Tankard, A. \& Balkwill, H.R. (eds.): Extensional Tectonics and Stratigraphy of the North Atlantic Margins, American Association of Petroleum Geologists Memoir 46, pp. 511-522.

Köhler, A., Maupin, V. \& Balling, N. 2015: Surface wave tomography across the Sorgenfrei-Tornquist Zone, SW Scandinavia, using ambient noise and earthquake data. Geophysical Journal International 203, 284-311. https://doi.org/10.1093/gji/ggv297.

Kolstrup, M.L., Hung, S.H. \& Maupin, V. 2015: Multiscale, finite-frequency $\mathrm{P}$ and $\mathrm{S}$ tomography of the upper mantle in the southwestern Fennoscandian Shield. Geophysical Journal International 202, 190-218. https://doi.org/10.1093/gji/ggv130.

Korchin, V.A. 2015: Low-velocity zones of thermobaric origin in the crystalline crust. Geophysical Journal 37, 46-65 (in Russian).

Kvarven, T., Ebbing, J., Mjelde, R., Faleide, J.I., Libak, A., Thybo, H., Flueh, E.R. \& Murai, Y. 2014: Crustal structure across the landocean transition off Møre, mid-Norway, from wide-angle seismic and gravity data. Tectonophysics 626, 21-40.

https://doi.org/10.1016/j.tecto.2014.03.021.

Kvarven, T., Mjelde, R., Hjelstuen, B.O., Faleide, J.I., Thybo, H., Flueh, E.R. \& Murai, Y. 2016: Crustal composition of the Møre Margin and compilation of a conjugate Atlantic margin transect. Tectonophysics 666, 144-157. https://doi.org/10.1016/j.tecto.2015.11.002.

Kyrkjebø, R., Hamborg, M., Faleide, J.I., Jordt, H. \& Christiansson, P. 2000: Cenozoic tectonic subsidence from 2D depositional simulations of a regional transect in the northern North Sea basin. In Nøttvedt, A. (ed.): Dynamics of the Norwegian Margin. Geological Society of London, Special Publication 167, pp. 273-294. https://doi.org/10.1144/GSL.SP.2000.167.01.11.

Kyrkjebø, R., Gabrielsen, R.H. \& Faleide, J.I. 2004: Unconformities related to the Jurassic-Cretaceous synrift-post-rift transition of the northern North Sea. Journal of the Geological Society of London 161, 1-17. https://doi.org/10.1144/0016-764903-051.

Lassen, A. \& Thybo, H. 2012: Neoproterozoic and Palaeozoic evolution of SW Scandinavia based on integrated seismic interpretation. Precambrian Research 204-205, 75-104.

https://doi.org/10.1016/j.precamres.2012.01.008.

Lie, J.E., Nilsen, E.H., Grandal, E., Grue, K. \& Sørlie, R. 2016: A Successful Geophysical Prediction of Fractured Porous Basement Reservoir - Rolvsnes Oil Discovery 2015, Utsira High. 78th EAGE Conference and Exhibition, 31. May 2016. https://doi.org/10.3997/2214-4609.201600593.

Ludwig, J.W., Nafe, J.E. \& Drake, C.L. 1970: Seismic refraction. In Maxwell, A.E. (ed.): The Sea, Wiley, New York, pp. 53-84.

Lundmark, A.M., Corfu, F., Spürgin, S. \& Selbekk, R.S. 2007: Proterozoic evolution and provenance of the high-grade Jotun Nappe Complex. SW Norway: U-Pb geochronology. Precambrian Research 159, 133-154. https://doi.org/10.1016/j.precamres.2006.12.015.

Lyngsie, S.B. \& Thybo, H. 2007: A new tectonic model for the Laurentia-Avalonia-Baltica sutures in the North Sea: A case study along MONA LISA profile 3. Tectonophysics 429, 201-227. https://doi.org/10.1016/j.tecto.2006.09.017.

Lyngsie, S.B., Thybo, H. \& Rasmussen, T.M. 2006: Regional geological and tectonic structures of the North Sea area from potential field modelling. Tectonophysics 413, 147-170.

https://doi.org/10.1016/j.tecto.2005.10.045.
Marello, L., Ebbing, J. \& Gernigon, L. 2013: Basement inhomogeneities and crustal setting in the Barents Sea from a combined 3D gravity and magnetic model. Geophysical Journal International 193, 557584. https://doi.org/10.1093/gji/ggt018.

Maupin, V. 2011: Upper-mantle structure in southern Norway from beamforming of Rayleigh wave data presenting multipathing. Geophysical Journal International 185, 985-1002. https://doi.org/10.1111/j.1365-246X.2011.04989.x.

Maupin, V., Agostini, A., Artemieva, I., Balling, N., Beekman, F., Ebbing, J., England, R.W., Frassetto, A., Gradmann, S., Jacobsen, B.H., Kohler, A., Kvarven, T., Medhus, A.B., Mjelde, R., Ritter, J., Sokoutis, D., Stratford, W., Thybo, H., Wawerzinek, B. \& Weidle, C. 2013: The deep structure of the Scandes and its relation to tectonic history and present-day topography. Tectonophysics 602, 15-37.

https://doi.org/10.1016/j.tecto.2013.03.010.

Maystrenko, Y.P. 2016: From structural data to 3D thermal model: an example from the northern North Sea. 15th EAGE International Conference on Geoinformatics - Theoretical and Applied Aspects, 10. May 2016.

Maystrenko, Y.P. \& Scheck-Wenderoth, M. 2013: 3D lithosphere-scale density model of the Central European Basin System and adjacent areas. Tectonophysics 601, 53-77.

https://doi.org/10.1016/j.tecto.2013.04.023.

Maystrenko, Y., Bayer, U. \& Scheck-Wenderoth, M. 2010: Structure and evolution of the Central European Basin System according to 3D modelling. German Society for Petroleum and Coal Science and Technology Research Report 577-2/2-1, Hamburg. 90 pp.

Maystrenko, Y.P., Bayer, U. \& Scheck-Wenderoth, M. 2012: Regionalscale structural role of Permian salt within the Central European Basin System. In Alsop, G.I., Archer, S.G., Hartley, A.J., Grant, N.T. \& Hodgkinson, R. (eds.): Salt Tectonics, Sediments and Prospectivity, Geological Society of London, Special Publications 363, pp. 409430. https://doi.org/10.1144/SP363.19.

Maystrenko, Y.P., Bayer, U. \& Scheck-Wenderoth, M. 2013: Salt as a 3D element in structural modeling: Example from the Central European basin system. Tectonophysics 591, 62-82.

https://doi.org/10.1016/j.tecto.2012.06.030.

Maystrenko, Y.P., Olesen, O. \& Elvebakk, H.K. 2015a: Indication of deep groundwater flow through the crystalline rocks of southern Norway. Geology 43, 327-330.

Maystrenko, Y.P., Slagstad, T., Elvebakk, H.K., Olesen, O., Ganerød, G.V. \& Rønning, J.S. 2015b: New heat flow data from three boreholes near Bergen, Stavanger and Moss, southern Norway. Geothermics 56, 79-92. https://doi.org/10.1130/G36318.1.

Maystrenko, Y.P., Olesen, O., Gernigon, L. \& Gradmann, S. 2017: Deep structure of the Lofoten-Vesterålen segment of the Mid-Norwegian continental margin and adjacent areas derived from 3D density modelling. Journal of Geophysical Research: Solid Earth 122, 1402-1433. https://doi.org/10.1002/2016JB013443.

Mazur, S., Mikolajczak, M., Krzywiec, P., Malinowski, M., Buffenmyer, V. \& Lewandowski, M. 2015: Is the Teisseyre-Tornquist Zone an ancient plate boundary of Baltica? Tectonics 34, 2465-2477. https://doi.org/10.1002/2015TC003934.

Mazur, S., Mikolajczak, M., Krzywiec, P., Malinowski, M., Lewandowski, M. \& Buffenmyer, V. 2016: Pomeranian Caledonides, NW Poland A collisional suture or thin-skinned fold-and-thrust belt. Tectonophysics 692,29-43. https://doi.org/10.1016/j.tecto.2016.06.017. 
McBride, J.H. \& England, R.W. 1999: Window into the Caledonian orogen: Structure of the crust beneath the East Shetland platform, United Kingdom. Geological Society of America Bulletin 111, 10301041.

https://doi.org/10.1130/0016-7606(1999)111<1030:WITCOS $>2.3$ .CO;2.

McEnroe, S., Robinson, P. \& Panish, P. 1996: Rock-magnetic properties, oxide mineralogy and mineral chemistry in relation to aeromagnetic interpretation and search for ilmenite reserves. NGU Report 96.060, $153 \mathrm{pp}$.

McKerrow, W.S., Mac Niocaill, C. \& Dewey, J.F. 2000: The Caledonian Orogeny redefined. Journal of the Geological Society of London 157, 1149-1154. https://doi.org/10.1144/jgs.157.6.1149.

Medhus, A., Balling, N., Jacobsen, B.H., Kind, R. \& England, R.W. 2009: Deep-structural differences in southwestern Scandinavia revealed by P-wave travel time residuals. Norwegian Journal of Geology 89, 203-214.

Medhus, A., Balling, N., Jacobsen, B., Weidle, C., England, R., Kind, R., Thybo, H. \& Voss, P. 2012: Upper-mantle structure beneath the Southern Scandes Mountains and the Northern Tornquist Zone revealed by P-wave traveltime tomography. Geophysical Journal International 189, 1315-1334.

https://doi.org/10.1111/j.1365-246X.2012.05449.x.

Menuge, J., Pedersen, R.B. \& Furnes, H. 1989: Seawater alteration of the Karmøy Ophiolite Complex, SW Norway: Nd and Sr isotopic evidence. Norwegian Journal of Geology 69, 191-200.

Mogensen, T.E. \& Korstgård, J. A. 2003: Triassic and Jurassic transtension along part of the Sorgenfrei-Tornquist Zone in the Danish Kattegat. In Surlyk, F. \& Ineson, J.R. (eds.): The Jurassic of Denmark and Greenland, Geological Survey of Denmark and Greenland Bulletin 1, pp. 439-458.

Morgan, R.K. 1990: Cenozoic subsidence and uplift in the North Sea region: implications for mechanism mechanisms of basin formation. Geological Society of London, Special Publications 55, 369. https://doi.org/10.1144/GSL.SP.1990.055.01.18.

Møller, J.J. \& Rasmussen, E.S. 2003: Middle Jurassic-Early Cretaceous rifting of the Danish Central Graben. In Surlyk, F., Ineson, J.R. (eds.), The Jurassic of Denmark and Greenland, Geological Survey of Denmark and Greenland Bulletin 1, pp. 247-264.

Mørk, M.B.E., McEnroe, S. \& Olesen, O. 2002: Magnetic susceptibility of Mesozoic and Cenozoic sediments off Mid Norway and the role of siderite: implications for interpretation of high-resolution aeromagnetic anomalies. Marine and Petroleum Geology 19, 1115-1126. https://doi.org/10.1016/S0264-8172(02)00115-0.

Nasuti, A., Brönner, M., Lauritsen, T. \& Olesen, O. 2013: 3D aeromagnetic processing and compilation of the COOP data. In Olesen, O., Bronner, M., Ebbing, J., Elvebakk, H., Gellein, J., Koziel, J., Lauritsen, T., Lutro, O., Maystrenko, Y., Müller, C., Nasuti, A., Osmundsen, P.T., Slagstad, T. \& Storrø G. (eds.): COOP Phase I - Crustal Onshore-Offshore Project, NGU Report 2013.002, pp. 9-29.

Nielsen, L., Balling, N., Jacobsen, B.H. \& MONA LISA Working Group, 2000: Seismic and gravity modelling of crustal structure in the Central Graben, North Sea. Observations along MONA LISA profile 3. Tectonophysics 328, 229-244.

https://doi.org/10.1016/S0040-1951(00)00213-4.

Nirrengarten, M., Gernigon, L. \& Manatschal, G. 2014: Lower-crustal bodies in the Møre volcanic rifted margin: Geophysical determination and geological implications. Tectonophysics 636, 143-157. https://doi.org/10.1016/j.tecto.2014.08.004.
NITG 2004: Geological Atlas of the Netherlands - onshore, scale 1:1,000,000, Netherlands Institute for Applied Geoscience TNO National Geological Survey (Utrecht), 103 pp.

Norwegian Petroleum Directorate (NPD) 2016: The NPD's fact pages; well data summary sheets.

http://factpages.npd.no/FactPages/Default.aspx?nav1=wellbore\&n av2=PageView|Exploration $\mid$ All\&nav3=6753 (November 2016).

Odinsen, T., Reemst, P., van der Beek, P., Faleide, J.I. \& Gabrielsen, R.H. 2000: Permo-Triassic and Jurassic extension in the northern North Sea: results from tectonostratigraphic forward modelling. In Nøttvedt, A. (ed): Dynamics of the Norwegian Margin, Geological Society of London, Special Publications 167, pp. 83-103. https://doi.org/10.1144/GSL.SP.2000.167.01.05.

Olesen, O., Reitan, M. \& Sæther, P.O. 1993: Petrofysisk Database PETBASE 3.0. Brukerbeskrivelse, NGU Report 93.023, Trondheim, Norway, $74 \mathrm{pp}$.

Olesen, O., Lundin, E., Nordgulen, O., Osmundsen, P.T., Skilbrei, J.R., Smethurst, M.A., Solli, A., Bugge, T. \& Fichler, C., 2002. Bridging the gap between the onshore and offshore geology in Nordland, northern Norway, Norwegian Journal of Geology 82, 243-262.

Olesen, O., Smethurst, M.A., Torsvik, T.H. \& Bidstrup, T. 2004: Sveconorwegian igneous complexes beneath the Norwegian-Danish Basin. Tectonophysics 387, 105-130.

https://doi.org/10.1016/j.tecto.2004.06.009.

Olesen, O., Brönner, M., Ebbing, J., Gellein, J., Gernigon, L., Koziel, J., Lauritsen, T., Myklebust, R., Pascal, C., Sand, M., Solheim, D. \& Usov, S. 2010: New aeromagnetic and gravity compilations from Norway and adjacent areas - methods and applications. In Vining, B.A. \& Pickering, S.C. (eds.): Petroleum Geology: From mature basins to new frontiers. Proceedings of the 7th Petroleum Geology Conference. Petroleum Geology Conference Series 7, Geological Society of London, pp. 559-586.

Ottemöller, L. \& Midzi, V. 2003: The crustal structure of Norway from inversion of teleseismic receiver functions. Journal of Seismology 7 , 35-48. https://doi.org/10.1023/A:1021294504092.

Pascal, C. 2015: Heat flow of Norway and its continental shelf. Marine and Petroleum Geology 66, 956-969. https://doi.org/10.1016/j.marpetgeo.2015.08.006.

Pascal, C. \& Olesen, O. 2009. Are the Norwegian mountains compensated by a mantle thermal anomaly at depth? Tectonophysics 475, 160-168. https://doi.org/10.1016/j.tecto.2009.01.015.

Pascal, C. \& Rudlang, T. 2016: Discovery of highly radioactive granite in the Bergen Region. Norwegian Journal of Geology 96, 319-328. https://doi.org/10.17850/njg96-4-03.

Pasquale, V. 2011: Curie Temperature. Encyclopedia of Solid Earth Geophysics, Encyclopedia of Earth Sciences Series, pp. 89-90. https://doi.org/10.1007/978-90-481-8702-7_109.

Pedersen, R.B. \& Hertogen, J. 1990: Magmatic evolution of the Karmøy ophiolite complex, SW Norway: relationships between MORB-IATboninitic-calc-alcaline and alkaline magmatism. Contributions to Mineralogy and Petrology 104, 277-293. https://doi.org/10.1007/BF00321485.

PGS Reservoir 2003: North Sea Digital Atlas - Version 2.0 (NSDA-2.0), Industrial report 2003, PGS Reservoir, Berks, UK.

Pharaoh, T.C. 1999: Palaeozoic terranes and their lithosphere boundaries within the Trans-European Suture Zone (TESZ): a review. Tectonophysics 314, 17-41. https://doi.org/10.1016/S0040-1951(99)00235-8. 
Piper, J.D.A. \& Poppelton, T.J. 1990: A palaeomagnetic study of the Basal Gneiss Region and Jotun Nappe Complex, central-southern Scandinavian Caledonides. Geophysical Journal International 101, $591-612$.

https://doi.org/10.1111/j.1365-246X.1990.tb05573.x.

Plein, E. 1990: The Southern Permian Basin and its paleogeography. In Heling, D., Rothe, P., Forstner, U., Staffers, P. (eds.): Sediments and Environmental Geochemistry - Selected Aspects and Case Histories, Springer-Verlag, Heidelberg, Germany, pp. 124-133.

https://doi.org/10.1007/978-3-642-75097-7_7.

Poppleton, T.J. \& Piper, J.D.A. 1990: Palaeomagnetism of a Caledonian ophiolite, Karmøy, SW Norway. Physics of the Earth and Planetary Interiors 61,297-314.

https://doi.org/10.1016/0031-9201(90)90113-C.

Ragnhildstveit, J. \& Helliksen, D. 1997: Geology map of Norway, Bergen, scale 1:250,000, Norges geologiske undersøkelse.

Riber, L., Dypvik, H. \& Sørlie, R. 2015: Altered basement rocks on the Utsira High and its surroundings, Norwegian North Sea. Norwegian Journal of Geology 93, 57-89.

https://doi.org/10.17850/njg95-1-04.

Riber, L., Dypvik, H., Sørlie, R. \& Ferrell, R.E. 2016: Clay minerals in deeply buried paleoregolith profiles, Norwegian North Sea. Clays and Clay Minerals 64, 588-607.

https://doi.org/10.1346/CCMN.2016.064036.

Roberts, D. \& Gee, D.G. 1985: An introduction to the structure of the Scandinavian Caledonides. In Gee, D. G. \& Sturt, B. A. (eds): The Caledonide Orogen - Scandinavia and Related Areas, Wiley, Chichester, pp. 55-68.

Sandrin, A. \& Thybo, H. 2008: Seismic constraints on a large mafic intrusion with implications for the subsidence mechanism of the Danish Basin. Journal of Geophysical Research 113, B09402. https://doi.org/10.1029/2007JB005067.

Sandrin, A., Nielsen, L. \& Thybo, H. 2009: Layered crust-mantle transition zone below a large crustal intrusion in the Norwegian-Danish Basin. Tectonophysics 472, 194-212.

https://doi.org/10.1016/j.tecto.2008.05.039.

Scheck-Wenderoth, M. \& Lamarche, J. 2005: Crustal memory and basin evolution in the Central European Basin System - new insights from a 3D structural model. Tectonophysics 397, 143-165. https://doi.org/10.1016/j.tecto.2004.10.007.

Schmidt, S. \& Götze, H.J. 1998. Interactive visualization and modification of 3D models using GIS functions. Physics and Chemistry of the Earth 23, 289-295.

https://doi.org/10.1016/S0079-1946(98)00027-5.

Sclater, J.G. \& Christie, P.A.F. 1980: Continental stretching: an explanation of the post-Mid-Cretaceous subsidence of the central North Sea basin. Journal of Geophysical Research 85, 3711-3739.

https://doi.org/10.1029/JB085iB07p03711.

Shomali, Z.H., Roberts, R.G., Pedersen, L.B. \& The TOR Working Group 2006: Lithospheric structure of the Tornquist Zone resolved by nonlinear $\mathrm{P}$ and $\mathrm{S}$ teleseismic tomography along the TOR array. Tectonophysics 416, 133-149.

Sigmond, E.M.O. 2002: Geological Map, Land and Sea Areas of Northern Europe, scale 1:4,000,000, Geological Survey of Norway.

Skilbrei, J.R. 1990: Structure of the Jotun Nappe Complex, southern Norwegian Caledonides: ambiguity of gravity modelling and reinterpretation. NGU Report 89.169, 26 pp.

Slagstad, T., Balling, N., Elvebakk, H., Midttømme, K., Olesen, O., Olsen, O. \& Pascal, C. 2009: Heat-flow measurements in Late Pal- aeoproterozoic to Permian geological provinces in south and central Norway and a new heat-flow map of Fennoscandia and the Norwegian-Greenland Sea. Tectonophysics 473, 341-361.

https://doi.org/10.1016/j.tecto.2009.03.007.

Slagstad, T., Maystrenko, Y.P., Maupin, V. \& Gradmann, S., in press. An extinct, Late Mesoproterozoic, Sveconorwegian mantle wedge beneath SW Fennoscandia, reflected in seismic tomography and assessed by thermal modeling. Terra Nova.

Slagstad, T., Roberts, N.M.W., Marker, M., Røhr, T.S. \& Schiellerup, H. 2013: A non-collisional, accretionary Sveconorwegian orogen. Terra Nova 25, 30-37. https://doi.org/10.1111/ter.12001.

Slagstad, T., Roberts, N.M.W., Kulakov, E. 2017: Linking orogenesis across a supercontinent; the Grenvillian and Sveconorwegian margins on Rodinia. Gondwana Research 44, 109-115. https://doi.org/10.1016/j.gr.2016.12.007.

Smelror, M., Cocks, L.R.M., Mørk, A., Neuman, B.E.E. \& Nakrem, H.A. 1997: Upper Ordovician-Lower Silurian strata and biota from offshore South Norway. Norwegian Journal of Geology 77, 251-268.

Smit, J., van Wees, J.D. \& Cloetingh, S. 2016: The Thor suture zone: From subduction to intraplate basin setting. Geology 44, 707-710. https://doi.org/10.1130/G37958.1.

Stemmerik, L., Ineson, J.R., Mitchell, J.G. 2000: Stratigraphy of the Rotliegend Group in the Danish part of the Northern Permian Basin, North Sea. Journal of the Geological Society of London 157, 11271136. https://doi.org/10.1144/jgs.157.6.1127.

Storvoll, V., Bjørlykke, K. \& Mondol, N.H. 2005: Velocity-depth trends in Mesozoic and Cenozoic sediments from the Norwegian shelf. American Association of Petroleum Geologists Bulletin 89, 359-381. https://doi.org/10.1306/10150404033.

Stratford, W. \& Thybo, H. 2011: Seismic structure and composition of the crust beneath the southern Scandes, Norway. Tectonophysics 502, 364-382. https://doi.org/10.1016/j.tecto.2011.02.008.

Stratford, W., Thybo, H., Faleide, J.I., Olesen, O. \& Tryggvason, A. 2009: New Moho map for onshore southern Norway. Geophysical Journal International 178, 1755-1765.

https://doi.org/10.1111/j.1365-246X.2009.04240.x.

Svenningsen, L., Balling, N., Jacobsen, B.H., Kind, R., Wylegalla, K. \& Schweitzer, J. 2007: Crustal root beneath the highlands of southern Norway from teleseismic receiver functions. Geophysical Journal International 170, 1129-1138.

https://doi.org/10.1111/j.1365-246X.2007.03402.x.

Sylvester, A.G. 1998: Magma mixing, structure, and re-evaluation of the emplacement mechanism of Vrådal pluton, central Telemark, southem Norway. Norwegian Journal of Geology 78, 259-276.

Tesauro, M., Kaban, M.K., Cloetingh, S.A.P.L., Hardebol, N.J. \& Beekman, F. 2007: 3D strength and gravity anomalies of the European lithosphere. Earth and Planetary Science Letters 263, 56-73. https://doi.org/10.1016/j.epsl.2007.08.035.

Tesauro, M., Kaban, M.K. \& Cloetingh, S.A.P.L. 2008: EuCRUST-07: A new reference model for the European crust. Geophysical Research. Letters 35, L05313.

https://doi.org/10.1029/2007GL032244.

Thybo, H. 2001: Crustal structure along the EGT profile across the Tornquist Fan interpreted from seismic, gravity and magnetic data. Tectonophysics 334, 155-190.

https://doi.org/10.1016/S0040-1951(01)00055-5.

Thybo, H. \& Nielsen, L. 2012: Seismic velocity structure of crustal intrusions in the Danish Basin. Tectonophysics 572-573, 64-75. https://doi.org/10.1016/j.tecto.2011.11.019. 
Thybo, H., Sandrin, A., Nielsen, L., Lykke-Andersen, H. \& Keller, G.R. 2006: Seismic velocity structure of a large mafic intrusion in the crust of central Denmark from project ESTRID. Tectonophysics 420, 105-122. https://doi.org/10.1016/j.tecto.2006.01.029.

Torsvik, T.H. \& Rehnström, E.F. 2003: The Tornquist Sea and BalticaAvalonia docking. Tectonophysics 362, 67-82. https://doi.org/10.1016/S0040-1951(02)00631-5.

Torsvik, T.H., Andersen, T.B., Eide, E.A. \& Wa1derhaug, H.J. 1997: The age and tectonic significance of dolerite dykes in western Norway. Journal of the Geological Society 154, 961-973. https://doi.org/10.1144/gsigs.154.6.0961.

Van der Auwera, J., Bolle, O., Bingen, B., Liégeois, J.P., Bogaerts, M., Duchesne, J.C., De Waele, B. \& Longhi, J. 2011: Sveconorwegian massif-type anorthosites and related granitoids result from postcollisional melting of a continental arc root. Earth Science Reviews 107, 375-397. https://doi.org/10.1016/j.earscirev.2011.04.005.

Vejbæk, O.V. 1997: Dybe strukturer i danske sedimentære bassiner. Geologisk Tidsskrift 4, 1-31.

Vejbæk, O.V. \& Britze, P. 1994: Geological map of Denmark. Top preZechstein (two-way traveltime and depth). Sub- and supercrop map, Map Series 45. 3 maps and 8 pp., scale 1:750,000, Geological Survey of Denmark.

Vejbæk, O.V. \& Andersen, C. 2002: Post mid-Cretaceous inversion tectonics in the Danish Central Graben-regionally synchronous tectonic events? Bulletin of the Geological Society of Denmark 49, 129-144.

Verhoef, J., Roest, W.R., Macnab, R., Arkani-Hamed, J. \& Members of the Project Team 1996: Magnetic Anomalies of the Arctic and North Atlantic Oceans and Adjacent Land Areas. Geological Survey of Canada Open File Report 3125, Parts a and b (CD-ROM and project report).

Voorhies, C.V., Sabaka, T.J. \& Purucker, M. 2002: On magnetic spectra of Earth and Mars. Journal of Geophysical Research (Planets) 107, E6 (5034), 1-10. https://doi.org/ 10.1029/2001JE001534.

Wawerzinek, B., Ritter, J. \& Roy, C. 2013: New constraints on the 3D shear wave velocity structure of the upper mantle underneath Southern Scandinavia revealed from non-linear tomography. Tectonophysics 602, 38-54.

https://doi.org/10.1016/j.tecto.2012.12.033.

White, N. 1989: Nature of lithospheric extension in the North Sea. Geology 17, 111-114.

https://doi.org/10.1130/0091-7613(1989)017<0111:NOLEIT>2.3 .CO;2.

Yegorova, T., Bayer, U., Thybo, H., Maystrenko, Y., Scheck-Wenderoth, M. \& Lyngsie, S.B. 2007: Gravity signals from the lithosphere in the Central European Basin System. Tectonophysics 429, 133-163. https://doi.org/10.1016/j.tecto.2006.10.002.

Zervos, F.A. 1986: Geophysical Investigation of Sedimentary Basin Development: Viking Graben, North Sea. PhD. thesis, University of Edinburgh, 169 pp.

Ziegler, P. 1990. Geological Atlas of western and central Europe (2.ed.), Shell International Petroleum Maatschappij BV, The Hague, The Netherlands, 256 pp.

Ziegler, P.A. \& Dèzes, P. 2006: Crustal evolution of Western and Central Europe, In Gee D.G. \& Stephenson, R.A. (eds.): European Lithosphere Dynamics, Geological Society of London, Memoirs 32, pp. 43-56. https://doi.org/10.1144/GSL.MEM.2006.032.01.03.

Åm, K. 1973: Geophysical indications of Permian and Tertiary igneous activity in the Skagerrak. NGU Bulletin 287, 1-25. 